\title{
ARTICLES \\ THE FiRST AMENDMENT Right to SPEAK AbOUT THE HUMAN GENOME
}

\author{
Barbara J. Evans* \\ Today, we celebrate the revelation of the first draft of the human book of \\ life. \\ Today, we are learning the language in which God created life. ${ }^{2}$
}

\section{INTRODUCTION}

The metaphor of the human genome as the Book of Life already was in wide use before June 26, 2000 when Dr. Francis Collins, Director of the National Human Genome Research Institute, and President Bill Clinton spoke these words at a White House gathering to celebrate the Human Genome Project. A search of the phrase "human genome book of life" in the National Library of Medicine's PubMed database yields thirty-one hits in the peer-reviewed scientific literature, ${ }^{3}$ including an anthropological study of how the "Book of Life" metaphor evolved in the popular press between 1990 and 2002." As sometimes happens in history, the revelation of a new sacred text devolved into spats about who is good enough to read it: Specifically,

* Professor of Law and George Butler Research Professor; Director, Center for Biotechnology \& Law, University of Houston Law Center. Contact bjevans@central.uh.edu. This work was supported by the Greenwall Foundation; by NIH grants U01HG006507 and U01HG007307; and by the University of Houston Law Foundation. The author would like to thank Wylie Burke, R. Alta Charo, Ellen Wright Clayton, I. Glenn Cohen, Gail P. Jarvik, Peter Linzer, Amy McGuire, Karen Rothenberg, Mark A. Rothstein, and Susan Brown Trinidad for their insightful comments.

1 Press Release, Office of the Press Secretary, Remarks by the President, Prime Minister Tony Blair of England, Dr. Francis Collins, Director of the National Human Genome Research Institute, and Dr. Craig Venter, President and Chief Scientific Officer, Celera Genomics Corporation, on the Completion of the First Survey of the Entire Human Genome Project (June 26, 2000) (remarks of Dr. Collins), available at http://www.ornl.gov/sci/techresources/Human_Genome/ project/clinton2.shtml.

2 Id. (remarks of President Clinton discussing the Human Genome Project).

$3 \quad$ PubMed database search conducted Jan. 25, 2013.

4 Iina Hellsten, From Sequencing to Annotating: Extending the Metaphor of the Book of Life from Genetics to Genomics, 24 NEW GENETICS \& SOC'Y. 283 (2005). 
is it wrong to grant ordinary laypeople direct access to the genomic Book of Life? This echoes a theme from the English Protestant Reformation, when there was consternation about translating the Bible into vernacular (English-language) text that laypeople could read for themselves. ${ }^{5}$ Sharing genetic test results directly with test subjects ${ }^{6}$ stirs similar sentiments.

"[A] substantial debate has erupted over whether to offer research participants individual research results, especially in genetic and genomic research." "7 The question here is whether people who volunteer to serve as participants in genetic research should be able to learn the results of the experimental genetic tests that investigators performed on them. Another debate concerns direct-to-consumer ("DTC") genetic tests that individuals can order directly from a laboratory without having a physician act as an intermediary. ${ }^{8}$ A third and larger debate concerns the very future of clinical medicine: Will the U.S. healthcare industry continue its "disease-oriented, reactive, and sporadic approach to care" in which medical professionals attempt to summon miracles to redeem patients after their descent into illness, or will it shift to a model of "prospective medicine" ${ }^{10}$ that harnesses patients' genetic and other diagnostic information in a lifelong, sustained journey to keep them well? This latter mode-also known as "P4 Medicine (Predictive, Preventive, Personalized, and Participatory)" — envisions a "far greater role for patient involvement" ${ }^{12}$ in a continuous process of risk assessment, health promotion,

5 See generally JAmes Simpson, Burning to ReAD: English Fundamentalism AND ITS REFORMATION OPPONENTS 2 (2007) (discussing the development, during the period 1520-1547, of a liberal reading culture in which individual religious adherents began to read holy scriptures for themselves without mediation by the clergy).

6 This Article uses the term "test subject" to refer to a person who has undergone laboratory testing either as a patient or as a research participant. A test subject is simply a person who has been tested with a genetic or other in vitro diagnostic test, either in a clinical or research setting.

7 Susan M. Wolf, The Challenge of Incidental Findings, 36 J.L. MED. \& ETHICS 216, 216 (2008); see also discussion and literature review infra Part II.

8 See, e.g., Jessica Elizabeth Palmer, Genetic Gatekeepers: Regulating Direct-to-Consumer Genomic Services in an Era of Participatory Medicine, 67 FOOD \& DRUG L.J. 475, 476-77 (2012) (discussing the challenges of regulating DTC genetic tests).

9 Ralph Snyderman \& Ziggy Yoediono, Perspective: Prospective Health Care and the Role of Academic Medicine: Lead, Follow, or Get Out of the Way, 83 ACAD. MED. 707, 707 (2008).

$10 I d$. (defining prospective health care as personalized, predictive, preventive, and participatory medicine).

11 Inst. For Sys. BIOlogy, ANnuAl Report: Pushing Boundaries 2 (2010) (report of Dr. Leroy Hood).

12 Snyderman \& Yoedino, supra note 9, at 707. 
and disease minimization. Greater patient involvement entails giving patients greater access to information than they have had in the past.

The common thread in all of these debates is that they are disputes about permissible flows of information from genetic and other diagnostic tests. Specifically, may a party (such as an investigator or a laboratory) that possesses a person's genetic test results communicate them to the test subject, or does law channel the communication through intermediaries or, perhaps, censor or suppress it altogether? Advances in the life sciences are "catalyzing a revolution in healthcare focused around an informational view of medicine." ${ }^{13}$ Old laws from the past constrain flows of genetic information ${ }^{14}$ and, in doing so, threaten this revolution. This Article explores whether the First Amendment can help clear away old laws that limit genomic speech.

Now, as in the Reformation, "[m] odernity and reading are intimately bound; the formation of one powerful strand of modernity in the sixteenth century was, in good part, produced by a profound transformation in the way Europeans read." ${ }^{15}$ The emergence of a liberal reading culture-premised on the capacity of individuals to read and debate the meaning of their sacred texts freely, directly, and unconstrained by intermediaries and institutional disciplines-was a "foundational element" of our modern understanding of ourselves. ${ }^{16}$ Construction of the human genome-the process of coming to an understanding of what the Book of Life means_-is fundamental to our future self-understanding. Recent battles over access to genetic information are fights about who is entitled to have a go at construing the genome's meaning. "Books can unleash terrific energies"17 and the human genome is no exception. People want to read it.

There is a fairly broad consensus among bioethicists and state and federal regulators that scientific investigators' communication of genetic test results to research participants should be subject to prior review and content-based restrictions on what the participants can be told. ${ }^{18}$ The recommended restrictions often include outright bans on the return of results that are scientifically uncertain, that lack a wellestablished clinical or reproductive significance, or that reveal risks

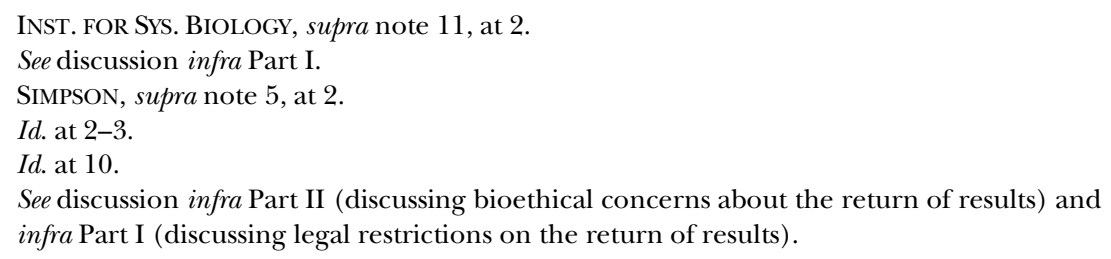


about which little can be done given the limitations of current medical knowledge. ${ }^{19}$ Yet, many research participants are curious about their genomes and want to know what researchers found out about them. ${ }^{20}$ Investigators may feel strongly inclined to answer their questions whether out of civility, fear of liability, or respect for the research participants, but they worry that doing so would violate a complex web of laws and regulations that restrict the return of experimental test results. ${ }^{21}$

Part I of this Article surveys these laws. Part II surveys bioethical recommendations to limit or suppress the return of results and surveys the bioethical rationales that support those recommendations. These include a litany of concerns about the dangers of communicating complex and uncertain genetic findings to scientifically naïe research participants. Doing so, it is feared, may mislead participants and potentially lead them to seek needless medical treatments or may inflict psycho-social harms such as making them feel anxious or stigmatized. ${ }^{22}$ Moreover, putting scientific information into the hands of laypeople may bring about broader social and economic harms: for example, wasteful healthcare spending as participants seek follow-up care in a quest to make sense of their genomes; depletion of research budgets by the allegedly high cost of returning results, and the possibility that laypeople may propagate non-canonical understandings of the genome within the social networks they form during their search to decipher what their genomes mean. ${ }^{23}$

No doubt unintentionally, the debate about return of results has taken on a striking resemblance to the 1520-1547 debate about translation of the English vernacular Bible. ${ }^{24}$ On one side of that debate were proponents of a liberal reading culture that welcomed ordinary laypeople to try their hand at interpreting canonical texts. "No longer blocked and oppressed by a mediating institution, the individual Christian [was] finally able to read the Biblical text for him- or her-

19 See discussion infra Part II

20 Lisa S. Parker, Returning Individual Research Results: What Role Should People's Preferences Play?, 13 MinN. J.L. SCI. \& TECH. 449, 456 (2012) ("What appears rather consistent across most of these studies is the finding that a substantial proportion of people express a desire for receiving research results.").

21 See discussion infra Part I (surveying various state and federal laws and regulations that restrict communication of experimental test results).

22 See infra Part II, Table 1.

23 Id.

24 See SimpSOn, supra note 5, at 4 (dating this period from the importation of Lutheran theology to England in 1520 to the death of Henry VIII in 1547 and the succession of an unequivocally Protestant king). 
self." ${ }^{25}$ A proponent of this view was William Tyndale who endured exile, burning of his works and, ultimately, execution at the age of forty-two for translating the Bible into English. ${ }^{26}$

On the other side of this debate were learned men who saw it as their duty to protect the public from the hazards of individual Biblereading. ${ }^{27}$ Some of their concerns rang of self-interest by entrenched stakeholders who feared "innovations, commotions, and mutations" 28 if the public were allowed to bypass established church institutions and intermediaries. But, part of their opposition reflected a sincere belief that it is safer for people to remain illiterate and rely on wiser minds to filter information for them. Some commentators argued that Bible-reading may provoke fear or self-loathing by forcing people to traverse (all alone) "a tightrope of terror across the abyss of damnation," ${ }^{29}$ presumably the sixteenth-century equivalent of discovering that one has two copies of a high-penetrance, harmful allele for which medical science offers no effective risk mitigation strategy. Moreover, scripture is difficult to understand $;{ }^{30}$ common people are too ignorant to understand it; ${ }^{31}$ and "misconstruction of the Scripture" can cause real harm: indeed, it can "slay the souls of men." John Stokesley, Bishop of London, felt it "abuseth the people in giving them liberty to read the scriptures, which doth nothing else but infect them with heresies." ${ }^{33}$ John Standish even complained that "servants have been stubborn and recalcitrant ever since vernacular scripture was available to them." " Then, as now, thought-leaders pressed for regulatory solutions. In 1542-1543, England enacted a statute entitled An Acte for the Advancement of True Religion to address disruptive translations that disseminate scripture to the public and

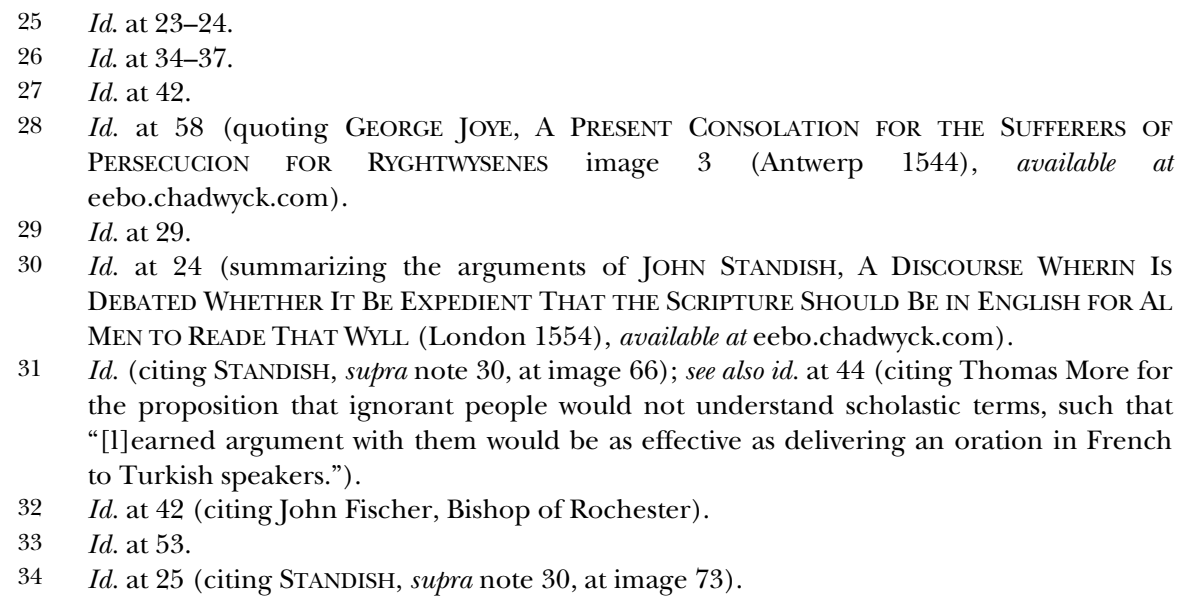

30 Id. at 24 (summarizing the arguments of JOHN STANDISH, A DisCOURSE WHERIN Is DEBATED WHETHER IT BE EXPEDIENT THAT THE SCRIPTURE SHOUld BE IN ENGLISH FOR AL MEN TO READE THAT WYLL (London 1554), available at eebo.chadwyck.com).

31 Id. (citing STANDISH, supra note 30, at image 66); see also id. at 44 (citing Thomas More for the proposition that ignorant people would not understand scholastic terms, such that "[1] earned argument with them would be as effective as delivering an oration in French to Turkish speakers.").

32 Id. at 42 (citing John Fischer, Bishop of Rochester).

34 Id. at 25 (citing STANDISH, supra note 30, at image 73).

$33 \quad I d$. at 53. 
"subvert the very true and perfect exposition ... of the said Scripture, after their perverse fantasies." 35

With the possible exception of Standish's beef with his unruly servants, the arguments against the vernacular Bible are eerily similar to modern bioethical arguments against the return of results from genetic research (and Standish's annoyance evokes the mutterings of modern clinicians whose patients pepper them with questions about medical articles that the patients gleaned from the Internet). The thesis of this Article is that a sizable contingent of bioethicists and policy-makers may have reasoned themselves onto the wrong side of history on the matter of individual access to genetic test results. When one arrives at consensus with Tyndale's executioners, the question does arise.

This Article focuses strictly on the return of experimental genetic test results although its findings also are relevant, with adaptations, to direct-to-consumer genetic tests and prospective medicine. Parts IIIIV of this Article explore whether legal restrictions on the return of results from genomic research may violate the First Amendment to the U.S. Constitution. ${ }^{36}$ Past literature on the return of research results has focused heavily on investigators' duties - that is, on identifying situations when an investigator has an ethical or legal obligation to inform a research participant of results that could have medical or other significance to the individual. ${ }^{37}$ This Article examines a different question: whether investigators have a right to communicate results to a research participant who has expressed the desire to receive them. This discussion presumes that the research participant has requested return of results so that there is a consenting recipient. Moreover, the investigator is potentially willing to share the information but is concerned that the requested communication may violate a law or regulation. This situation sets up the inquiry: Is the return of results to a willing research subject a form of speech that is

$35 \quad I d$. at 54.

36 Strictly speaking, the First Amendment addresses federal restrictions on speech, but under the Fourteenth Amendment, state-law restrictions on speech also are subject to First Amendment scrutiny.

37 See, e.g., Susan M. Wolf, The Role of Law in the Debate over Return of Research Results and Incidental Findings: The Challenge of Developing Law for Translational Science, 13 MiNN. J.L. SCI. \& TECH. 435, 435-37 (2012) (noting concerns about potential liability for failure to return results); Ellen Wright Clayton \& Amy L. McGuire, The Legal Risks of Returning Results of Genomic Research, 14 GENETICS MED. 473, 475 (2012) (noting concerns despite the absence of statutory duties to return research results and a lack of lawsuits to date that found a tort duty to return such results). 
entitled to protection under the First Amendment, such that laws that block such speech may be unconstitutional?

The phrase "return of results" will refer to communication of individual results from a test performed in the context of research. This Article conceives the return of results in its most general sense without any presumption about whether the results have analytical validity, ${ }^{38}$ clinical validity, ${ }^{39}$ or clinical utility ${ }^{40} /$ actionability. ${ }^{41}$ There also is no presumption about whether the result pertains to a focal or non-focal variable of the research study - that is, whether the result pertains to a gene that researchers specifically were studying or is an unrelated health finding that they happened to notice while examining the research participant or her test results. Unless expressly noted otherwise, return of results could involve any quality or type of results. At one end of the spectrum, this includes well-validated results with high clinical or reproductive importance. At the other end, it includes results with uncertain significance or dubious accuracy. The discussion does, however, explore how the First Amendment analysis may vary depending on what is being returned (well-validated, medically significant results vs. results of uncertain significance).

In contrast, much of the bioethical literature on this subject focuses on return of results that have clinical or reproductive signifi-

38 See Sec'y's Advisory Comm. On Genetic Testing, Enhancing the Oversight of GENETIC TESTS: RECOMMENDATIONS OF THE SACGT 15 (2000), available at http://oba.od.nih.gov/oba/sacgt/reports/oversight_report.pdf [hereinafter SACGT, 2000 REPORT] (explaining that analytical validity is an indicator of how well a test measures the property or characteristic it is intended to measure and addresses such matters as the test's accuracy, rate of false positives and negatives, and reliability in the sense of repeatedly getting the same result).

$39 I d$. at 15 n.11 (explaining that clinical validity refers to the accuracy with which a test predicts the presence or absence of a clinical condition or predisposition; it addresses whether there is a strong and well validated association between having a particular gene variant and having a particular health condition and whether knowing that a person has the gene variant offers meaningful insight into the person's health or reproductive risks); see Richard R. Fabsitz et al., Ethical and Practical Guidelines for Reporting Genetic Research Results to Study Participants: Updated Guidelines from a National Heart, Lung, and Blood Institute Working Group, 3 CiRCUlation CARDIOvascular GENETICS 574, 575 (2010) (expressing this concept by stating that a test result has an "established" meaning).

40 SACGT, 2000 REPORT, supra note 38, at $15 \mathrm{n} .12$ ("Clinical utility refers to the usefulness of the test and the value of the information to the person being tested. If a test has utility, it means that the results- positive or negative-provide information that is of value to the person being tested because he or she can use that information to seek an effective treatment or preventive strategy. Even if no interventions are available to treat or prevent the disease or condition, there may be benefits associated with knowledge of the result.").

41 Fabsitz et al., supra note 39, at 575 ("Actionable means that disclosure has the potential to lead to an improved health outcome; there must be established therapeutic or preventive interventions available or other available actions that may change the course of the disease."). 
cance. For example, studies led by Professor Susan Wolf have defined incidental findings ("IFs") ${ }^{42}$ and individual research results ("IRRs"). ${ }^{43}$ Both IFs and IRRs are findings about an individual research participant that have "potential health or reproductive importance." The distinction between IFs and IRRs turns on whether the finding pertains to a focal or non-focal variable in the study - that is, whether the finding arose within or outside the aims of the study. ${ }^{45}$ Wolf's research recognizes that this focal/non-focal distinction may have limited utility in the context of whole-exome, whole-genome, or genome-wide association studies where much or all of the genome is being studied, but it cites practical reasons for distinguishing IFs and IRRs. ${ }^{46}$ In this Article, return of results includes the return of IFs and IRRs, but also could include communicating additional findings that lack health or reproductive importance. Returning results is simply the act of letting research participants "know what has been learned about them" ${ }^{\text {"47 }}$ even if a truthful disclosure would need to point out that the results are of uncertain quality and/or significance.

Spurred by the advent of the printing press, the vernacular Bible was "unstoppably popular" ${ }^{48}$ despite thought-leaders' concerns that it would slay its readers' souls. Some of the newly empowered sixteenth-century readers left written accounts of the intensity and

42 See Susan M. Wolf et al., Managing Incidental Findings in Human Subjects Research: Analysis and Recommendations, 36 J.L. MED. \& ETHICS 219, 219 (2008) ("An IF [incidental finding] is a finding concerning an individual research participant that has potential health or reproductive importance and is discovered in the course of conducting research but is beyond the aims of the study.").

43 See Susan M. Wolf et al., Managing Incidental Findings and Research Results in Genomic Research Involving Biobanks and Archived Data Sets, 14 GENETICS MED. 361, 364 (2012) (“[A]n IRR [individual research result] is a finding concerning an individual contributor that has potential health or reproductive importance and is discovered in the course of research, when the finding is on the focal variables under study in meeting the stated aims of the research project.”).

44 See Wolf et al., supra note 42, at 219; Wolf et al., supra note 43 at 364.

45 Wolf et al., supra note 42, at 219; Wolf et al., supra note 43 at 364.

46 See Wolf et al., supra note 43, at 364 (noting that some institutions' policies recognize this difference); see also Wolf et al., supra note 42, at 231 (noting that investigators are more likely to have expertise for interpreting individual research results that are within the scope of a study but may lack expertise to interpret incidental findings that are outside the scope of their research).

47 See 1 Nat'l Bioethics Advisory Comm'n, Research Involving Human Biological MATERIALS: ETHICAL Issues AND POLICY GUIDANCE 72 (1999) [hereinafter 1 NBAC, 1999 REPORT] (explaining that some writers, including R.M. Veatch, favor the return of interim results on the basis that research participants have a right to know what has been learned about them) (citation omitted). 
sweetness of reading the scriptures for themselves. ${ }^{49}$ As advances in genome sequencing technology bring us closer to the $\$ 1000$ genome that ordinary people will be able to afford, many are burning to read this latest Book of Life wherein, to borrow words from Tyndale's Preface, "every syllable pertaineth to thine own self." Return of results is the act of opening the Book of Life and letting research participants peek into its pages. Does the First Amendment protect the modern Tyndales who engage in these forbidden conversations?

\section{RESTRICTIONS ON THE RETURN OF RESEARCH RESULTS}

Several interrelated sources of law potentially restrict communication of genetic test results to research participants. These are summarized below and contrasted with other restrictions that exist but are non-legal in nature.

\section{A. State Statutes and Regulations}

Some ethicists advise that " $[\mathrm{w}]$ henever IFs are to be disclosed, they should be disclosed directly to the research participant." ${ }^{\text {51 }}$ Even when this approach has ethical advantages, it may raise legal issues in a number of U.S. states, because some states restrict the ability of laboratories to report test results directly to test subjects. A recent survey of fifty-five U.S. states and territories found thirteen jurisdictions that only allow test results to be reported to a healthcare provider. ${ }^{52}$ Seven more states allow results to be disclosed directly to the test subject only with the provider's approval. ${ }^{53}$ These twenty states treat healthcare providers as intermediaries or gatekeepers in any communication between laboratories and test subjects. Only nine jurisdictions (including seven states, the District of Columbia, and Puerto Rico) provide a mechanism for reporting test results directly to the test subject. ${ }^{54}$

\footnotetext{
$49 \quad I d$. at 57.

$50 \quad$ Id. at 57 (citing Tyndale's Old Testament 8 (William Tyndale trans., David Daniell ed., 1992)).

51 Wolf et al., supra note 42, at 240.

52 CLIA Program and HIPAA Privacy Rule; Patients' Access to Test Results, 76 Fed. Reg. 56712, 56717 (proposed Sept. 14, 2011) (to be codified 42 C.F.R. pt. 493 and 45 C.F.R. pt. 164) (citing P. Jon White \& Jodi Daniel, RTI InT'L, Privacy AND SEcurity SOlutions FOR INTEROPERABLE HEALTH INFORMATION EXCHANGE: RELEASING CLINICAL LABORATORY TeSt RESults: REPORT ON SURVEY OF STATE LAWS (2009)).

$53 \quad I d$

$54 \quad I d$.
} 
The law is silent in the remaining twenty-six states and territories: direct reporting of results to test subjects is not forbidden but neither does the law allow it. ${ }^{55}$ When law is silent, other sources of norms such as professional standards, customs, or investigators' own beliefs may determine test subjects' access to their results. Informal norms of this sort ordinarily do not count as legal restrictions on the return of results unless they are enforceable by law, for example, if a state's medical licensure laws allow disciplinary action for violation of a professional ethics norm. ${ }^{56}$ Ethical standards that restrict speech can raise constitutional questions, just as a law would do, if compliance with the standards is obligatory under a law or regulation. Professional standards of ethics have been challenged on First Amendment grounds in situations where states used disbarment or disciplinary proceedings to enforce attorneys' compliance with standards of legal ethics. ${ }^{57}$

\section{B. State Common Law}

To date, investigators have not actually faced tort lawsuits in relation to return of genetic test results. ${ }^{58}$ Medical malpractice cases can arise only in the context of medical practice activities. ${ }^{59}$ Return of results, even though it may address topics that also arise during medical practice encounters, is distinct from the practice of medicine. ${ }^{60}$ "Because the express or implied consent of the physician is required" in

$55 \quad I d$

56 See Robert Post, Informed Consent to Abortion: A First Amendment Analysis of Compelled Physician Speech, 2007 U. ILL. L. REV. 939, 947-48 (discussing the ability of states to regulate "professional speech," or communications professionals make in the course of their professional practices, through various mechanisms such as disciplinary license proceedings and medical malpractice actions aimed at maintaining reasonable standards of competency and compliance with professional standards).

57 See, e.g., In re R.M.J., 455 U.S. 191, 193-96 (1982) (challenging standards of legal ethics that sought to protect clients from misleading speech by restricting the words attorneys could use to describe their qualifications and practice areas); Bates v. State Bar of Ariz., 433 U.S. 350, 353 (1977) (challenging ethical rules restricting advertising by attorneys).

58 See Clayton \& McGuire, supra note 37, at 475 (noting that no lawsuits have found investigators liable for failure to return results); see also Wolf, supra note 37, at 436-37 (noting the apparent absence of suits for mishandling this issue in either direction-either failing to return findings or for wrongly doing so).

59 See Daniel Halberstam, Commercial Speech, Professional Speech, and the Constitutional Status of Social Institutions, 147 U. PA. L. REv. 771, 844 (1999) (“[A] plaintiff in a malpractice case must demonstrate that the challenged advice not only was issued by a physician, but that it was conveyed in the context of a physician-patient relationship.”).

60 See Barbara J. Evans, Minimizing Liability Risks Under the ACMG Recommendations for Reporting Incidental Findings in Clinical Exome and Genome Sequencing, 15 GenteTiCS MED. 915 (2013); see also discussion infra Part IV.E. 
order for a physician-patient relationship to come into being, "the physician must take some affirmative action with regard to treatment of a patient in order for the relationship to be established." ${ }^{\prime 1}$ Even assuming the research investigator happens to be a physician, the return of results does not involve the critical treatment step. "A physician-patient relationship is not established by the mere act of a physician agreeing to see a patient at a later time or suggesting that the patient contact another physician." ${ }^{62}$ A medical malpractice suit based on return of results seemingly must founder because return of results is not the practice of medicine. ${ }^{63}$

This fact has not stopped investigators and commentators from feeling concern about potential legal liability either "for failure to return findings on one side, [or] . . f for wrongly returning on the other." ${ }^{\text {"64 }}$ Unlike state statutes and regulations that can actually ban behaviors, tort lawsuits allow the behavior to occur, but may impose sanctions (such as requiring the payment of damages) for engaging in the behavior. ${ }^{65}$ Clearly, though, the threat of having to pay damages can discourage behavior just as effectively as an outright ban would do. Assiduous worriers are able to envision scenarios in which an investigator might be sued for returning results: for example, for negligently returning results that later prove wrong, for returning results without obtaining a properly informed consent to do so, or for inflicting emotional or physical harms by returning results. Such suits (and the perceived threat of such suits) chill the return of results and thus constitute a legal restriction on the return of results. Again, this liability remains largely theoretical at present as no cases appear to have been brought as of this date.

\section{Federal Restrictions on Communication of Results from CLIA-Certified Laboratories}

The Clinical Laboratory Improvement Amendments of 1988 ("CLIA") place various restrictions on the communication of results

\footnotetext{
61 Amy G. Gore et al., Relation of Physician and Patient: Consensual Relationship and Contractual Agreements, 61 AM. Jur. 2D Physicians, SuRgEOns, ETC. $\$ 130$ (updated Feb. 2013).

62 Id. (citing Irvin v. Smith, 31 P.3d. 934, 941 (Kan. 2001) and Adams v. Via Christi Reg'l Med. Ctr., 19 P.3d 132, 140 (Kan. 2001), as corrected May 9, 2001).

63 See, e.g., Ande v. Rock, 647 N.W.2d 265 (Wis. Ct. App. 2002) (deciding, in a suit involving non-return of a diagnosis of cystic fibrosis in a research setting, that research is not the practice of medicine); see also discussion infra Part IV.E.

64 Wolf, supra note 37 , at 437.

65 See Geier v. Am. Honda Motor Co., 529 U.S. 861, 864-65 (2000) (discussing the difference between statutory proscriptions and tort sanctions).
} 
to test subjects. Even when testing is performed at a CLIA-certified lab, returning results directly to test subjects may be unlawful for reasons explained below. The current CLIA regulation at 42 C.F.R. $\S 493.1291$ (f) limits disclosure of test results from CLIA-compliant labs to three categories of persons. First, CLIA allows disclosure of test results to "authorized persons, ${ }^{, 66}$ which CLIA defines as including those authorized by state law to order or receive test results. ${ }^{67}$ In states that restrict the reporting of results to individual test subjects, CLIA incorporates those same restrictions. In 2011, the Department of Health and Human Services ("HHS") proposed to amend the CLIA regulation to allow test subjects to have greater access to their own test results, ${ }^{68}$ but the final rule has not yet been issued. Until an amended regulation goes into effect, test subjects can receive direct access to results from CLIA-compliant labs only in states that allow direct reporting. When state law is silent, HHS interprets CLIA as treating individual test subjects as authorized persons. ${ }^{69}$ Thus, HHS views CLIA as allowing disclosure of results to test subjects in the nine states and territories that expressly allow it and in the twenty-six jurisdictions where law is silent. ${ }^{70}$ The remaining two categories of persons who can receive CLIA-certified test results are as follows: CLIAcertified labs may report results to the person responsible for using the test results in the treatment context- that is, to a healthcare provider. $^{71}$ Also, in the case of reference labs, CLIA allows reporting of results to the referring lab. ${ }^{72}$

An important caveat is that the CLIA amendments proposed in 2011 would not apply to all laboratories, but only to CLIA-compliant labs that also are subject to the major federal privacy regulation known as the HIPAA Privacy Rule. ${ }^{73}$ Section 164.524 of the HIPAA Privacy Rule grants patients a right to inspect and obtain copies of the patients' own protected health information that doctors, hospi-

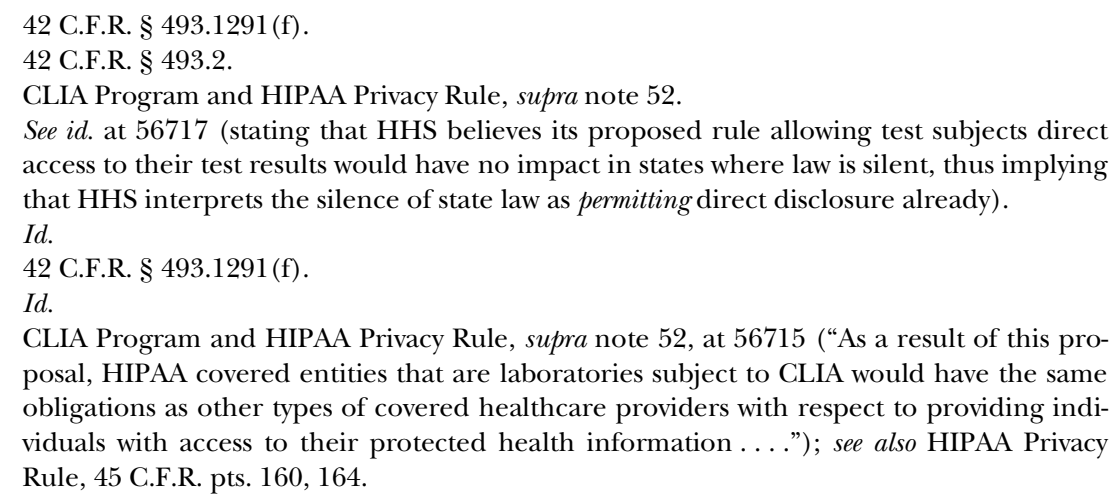
posal, HIPAA covered entities that are laboratories subject to CLIA would have the same obligations as other types of covered healthcare providers with respect to providing individuals with access to their protected health information ...."); see also HIPAA Privacy Rule, 45 C.F.R. pts. 160, 164. 
tals, and other HIPAA-covered healthcare providers hold in "designated record sets" ("DRS"). ${ }^{74}$ A DRS includes medical and billing records and other information " $[\mathrm{u}] \mathrm{sed}$ in whole or in part, by or for the covered entity to make decisions about individuals." ${ }^{75}$ CLIAcompliant laboratories traditionally have enjoyed an exception and were not subject to this $\S 164.524$ disclosure requirement. ${ }^{76}$ Thus, the HIPAA Privacy Rule gave patients access to the test results that labs had reported to physicians or hospitals, but not to other information generated during the testing process and stored in the lab's own files. This difference is crucially important in an era of whole genome and exome sequencing, which test many thousands of genetic variants within a person's genome, many of which may be irrelevant to the disease that caused the physician to order the testing and which therefore may never be reported back to the physician. ${ }^{77}$ To have access to all the personal genetic information generated during testing, test subjects need a right of access to information held by labs. The CLIA amendments proposed in 2011 seemingly would give test subjects that right with respect to genetic information held by CLIAcompliant labs that are subject to the HIPAA Privacy Rule. ${ }^{78}$ Even after these amendments, however, there will be ongoing problems with

74 See 45 C.F.R. $\$ 164.524$ (a) (1) (describing the individual's general right to inspect and obtain a copy of protected health information about the individual in a designated record set).

$75 \quad 45$ C.F.R. $§ 164.501$ (defining the term "designated record set").

$76 \quad 45$ C.F.R. $\$ 164.524$ (a) (1) (iii).

77 See generally James P. Evans, Return of Results: Not That Complicated?, 14 GENETICS MED. $358,358-59$ (2012) (describing whole genome sequencing and explaining that it may generate large amounts of extra genetic information that has questionable relevance to human health, which some test subjects may nevertheless want to know).

78 See 45 C.F.R. $\$ 160.103$ (clarifying, in recent revisions to the HIPAA Privacy Rule, that genetic information is health information for purposes of HIPAA); see also U.S. Dep't. of Health \& Human Servs., Off. of the Ass't Sec'y for Planning and Evaluation, Standards for Privacy of Individually Identifiable Health Information (Final Rule), 65 Fed. Reg. 82,462, 82,605-06 (Dec. 28, 2000) (providing guidance on the meaning of the term "designated record set" and noting that a DRS includes information that "may be used" (not merely is used) "in whole or in part" to make decisions about individuals; that it includes all data that "are normally used, and are reasonably likely to be used, to make decisions" and not just information that "already has been used"; that it "includes records that are used to make decisions about any individuals, whether or not the records have been used to make a decision about the particular individual requesting access"; and that the DRS is not limited to data "used to make healthcare decisions, because other decisions by covered entities can also affect individuals' interests.”). This guidance strongly suggests the 2011 proposed rule change would grant test subjects access not just to completed test reports but to most or all of the genetic information that a CLIA-compliant, HIPAA-covered laboratory has on file about them. 
individual access to data held by non-CLIA labs and labs that are not subject to the HIPAA Privacy Rule.

\section{Federal Restrictions on Communication of Results from Non-CLIA- Certified Research Laboratories}

The regulation at 42 C.F.R. $\S 493.3$ (b) (2) is commonly known as the CLIA research exception. It allows research laboratories to operate without CLIA certification provided they adhere to certain limits on their activities. CLIA's certification requirements are triggered if research laboratories "report patient specific results for the diagnosis, prevention or treatment of any disease or impairment of, or the assessment of the health of individual patients." ${ }^{\text {,79 }}$ There has been ongoing debate about how to interpret this provision. Seemingly authoritative sources assert that the CLIA regulations "prohibit the return of results to patients unless the laboratory is CLIA certified." CLIA training materials assert that CLIA "[i]ncludes research when results are returned [and] specimens have unique ID." ${ }^{\text {1 }}$ These statements interpret $\S 493.3$ (b) (2) as requiring CLIA certification if patient-specific results are returned for any purpose. Quite clearly, that is not what the regulation says.

As the Supreme Court has noted, "[T]he meaning of a statute must, in the first instance, be sought in the language in which the act is framed." ${ }^{82}$ The same is true of regulations: the best guide to their meaning is to read them. Section 493.3(b) (2) requires CLIA certification only if a laboratory reports results for specific, enumerated purposes: diagnosis, treatment, and prevention of disease and assessment of health. According to the plain text of the regulation, returning results for other purposes does not trigger CLIA's certification requirements. By analogy, a regulation that requires people to hold a driver's license if they use a car for driving does not require a license if they use a car for other purposes (such as riding, investing, or living in the car). In construing legal texts, courts "lean in favor of

$79 \quad 42$ C.F.R. $§ 493.3$ (b) (2).

80 SEC'y's ADVISORY COMM. ON GENETICS, HEALTH \& SOC'Y, U.S. SySTEM OF OVERSIGHT OF Genetic Testing: A Response to the Charge of the Secretary of Health and HUMAN SERVICES 128 (2008) [hereinafter "SACGHS, 2008 REPORT"].

81 Judy Yost, Div. of Lab. Servs., Ctrs. for Medicare \& Medicaid Servs., Quick CLIA 101 \& CLIA Compliance sl. 3 (2003) (unpublished visual presentation), available at http://oba.od.nih.gov/oba/sacghs/meetings/October2003/Yost.pdf.

82 See, e.g., Caminetti v. United States, 242 U.S. 470, 485 (1917); Barnhart v. Walton, 535 U.S. 212, 225 (2002); see also 2A NORMAN J. Singer \& J.D. SHAMbIE Singer, SutherLAND STATUTORY CONSTRUCTION $\S 46: 1$ (7th ed. 2007) (discussing the plain meaning rule). 
a construction which will render every word operative, rather than one which may make some of them idle and nugatory." 83 This "surplusage canon" of legal construction requires that "[i]f possible, every word and every provision is to be given effect... . None should be ignored" or treated as having no consequence. ${ }^{84}$ Administrative law judges follow this canon when interpreting the CLIA statute and regulations. ${ }^{85}$ It violates the surplusage canon to assert that any return of patient-specific results triggers a need for CLIA certification. Doing so ignores an important qualifying clause: CLIA certification is required only if labs "report patient specific results for the diagnosis, prevention or treatment of any disease or impairment of, or the assessment of the health of individual patients. ${ }^{" 66}$

Unfortunately, the CLIA regulations do not define what it means for a report to be for the enumerated purposes (as opposed to being for some other purpose). CLIA stratifies legal compliance obligations based on the purpose of lab test results, yet it supplies no guidance on how this purpose should be assessed. This is a serious defect of the CLIA regulations. For comparison, consider the U.S. Food and Drug Administration's ("FDA") medical device regulations. They also stratify regulatory compliance obligations based on a test's purpose. If an in vitro diagnostic product is "intended for use in the diagnosis of disease, ${ }^{87}$ the manufacturer must comply with certain FDA labeling requirements. ${ }^{88}$ Devices "intended for processing, repacking, or use in the manufacture of another drug or device" are exempt from these requirements. ${ }^{89}$ As in CLIA's research exemption, having a diagnostic purpose gives rise to regulatory compliance obligations.

Unlike CLIA, however, the FDA device regulations define how to assess a device's purpose. ${ }^{90}$ Such an assessment requires decisions

83 Thomas M. CoOley, A Treatise on the Constitutional Limitations Which Rest UPON THE LEGISLATIVE POWER OF THE STATES OF THE AMERICAN UNION 58 (1868).

84 See ANTONin SCALIA \& BRYAN A. GARNER, REAding LAW: INTERPRETATION OF LEGAL TEXTS 174-79 (2012) (discussing the surplusage canon).

85 See, e.g., In re Blanding Urgent Care Ctr. Lab. v. Health Care Fin. Admin., No. CR438, 1996 WL 600630, at *1, *14 (Dep't of Health \& Human Servs. Sept. 30, 1996) ("A cardinal rule of statutory construction is to interpret the statute in such a way that no part is rendered meaningless.").

$86 \quad 42$ C.F.R. $\$ 493.3$ (b) (2) (emphasis added).

8721 C.F.R. $\$ 801.119$.

88 See Federal Food, Drug, and Cosmetic Act, 21 U.S.C. $\$ 352(\mathrm{f})$ (1) (requiring adequate directions for use); see also 21 C.F.R. $§ 809.10$ (describing labeling requirements for in vitro diagnostic products).

8921 C.F.R. $\$ 801.122$.

90 21 C.F.R. $\$ 801.4$ ("The words intended uses or words of similar import in $\$ \S 801.5$, 801.119 , and 801.122 refer to the objective intent of the persons legally responsible for the labeling of devices. The intent is determined by such person's expressions or may be 
about a number of matters. Obviously, a key question is whether diagnostic purpose will be gauged by the intent of the device manufacturer or by how the device actually is used by practitioners and patients. If intent is determinative, then what sources of evidence will the FDA use to infer the manufacturer's subjective intent? For example, will the agency consider only product labeling, advertisements, and official statements by the manufacturer, or will it also consider statements by sales representatives and informal statements (such as a manufacturer's internal e-mails)? What happens if a manufacturer does not intend a device to be used for a diagnostic purpose yet is aware it is being so used? Does delivering a device with awareness that it will be put to an unintended use constitute intent for the device to have that use, or not? If persons other than the manufacturer alter a device's intended use, are they (rather than the manufacturer) responsible for complying with the FDA regulations? All of these questions are addressed in the FDA's definition of "intended use" ${ }^{\prime 11}$ and in court cases that have interpreted the meaning of that phrase. ${ }^{92}$

In contrast, the CLIA regulation fails to explain how the regulator will assess the purpose of a test report. Consequently, the CLIA regulation is vague in the sense that a person of ordinary intelligence would not necessarily know what the regulation prohibits. Indeed,

shown by the circumstances surrounding the distribution of the article. This objective intent may, for example, be shown by labeling claims, advertising matter, or oral or written statements by such persons or their representatives. It may be shown by the circumstances that the article is, with the knowledge of such persons or their representatives, offered and used for a purpose for which it is neither labeled nor advertised. The intended uses of an article may change after it has been introduced into interstate commerce by its manufacturer. If, for example, a packer, distributor, or seller intends an article for different uses than those intended by the person from whom he received the device, such packer, distributor, or seller is required to supply adequate labeling in accordance with the new intended uses. But if a manufacturer knows, or has knowledge of facts that would give him notice that a device introduced into interstate commerce by him is to be used for conditions, purposes, or uses other than the ones for which he offers it, he is required to provide adequate labeling for such a device which accords with such other uses to which the article is to be put.").

$91 \quad I d$.

92 See, e.g., United States v. An Undetermined No. of Unlabeled Cases, 21 F.3d. 1026, 102829 (10th Cir. 1994) (determining that specimen collection containers used in testing for the presence of HIV were "intended for use in diagnosis of disease" as this phrase is understood in the Food, Drug, and Cosmetic Act, even though the specimen containers had been used as part of a protocol that produced inconclusive diagnostic results); United States v. 25 Cases, More or Less, of an Article of Device, 942 F.2d 1179, 1181-83 (7th Cir. 1991) (holding that the term "diagnosis" in 21 U.S.C. $\$ 321(\mathrm{~h})(2)$ encompasses articles that screen for possible symptoms of disease even if the screening does not provide final identification of the condition). 
people with considerable expertise may find this regulation unclear. Exemplifying this uncertainty, Wolf et al. warn that 42 C.F.R. $\S$ 493.3(b) (2) "may mean that under current regulations, research labs may not report 'research results' when these are individual-specific and may be used to assess health or trigger such assessment." ${ }^{93}$ While it seems unlikely that a court would hold that urging a person to seek a health assessment is itself a health assessment, the sheer vagueness of CLIA's research exception does invite such speculation. To date, no court cases have clarified the meaning of the phrase "for the diagnosis, prevention or treatment of any disease or impairment of, or the assessment of the health of individual patients" in $\S 493.3$ (b) (2). ${ }^{94}$

CLIA certification clearly seems to be required when investigators plan to use test results in a way that affects the course of care for study participants (for example, to assign participants to the treatment arm of a study). ${ }^{95}$ If test results are not so used, clinicians and investigators confront a legal gray area: Does merely communicating test results to study participants amount to the type of reporting that, under $\S 493.3$ (b) (2), triggers a need for CLIA compliance? This legal uncertainty is chilling communication of results from non-CLIAcertified labs. A National Heart, Lung, and Blood Institute ("NHLBI") Working Group noted that there is significant disagreement about "what constitutes compliance with the CLIA regulations for the return of research results in genetics studies" and that " $[\mathrm{t}] \mathrm{his}$ is a high-impact issue." 96

\section{E. Federal Restrictions on Communication Under the Common Rule}

As a condition of receiving research funding from the National Institutes of Health ("NIH"), investigators are required to comply with the Federal Policy for the Protection of Human Subjects, ${ }^{97}$ or "Common Rule." ${ }^{98}$ The Common Rule requires approval and ongoing oversight of research by an Institutional Review Board ("IRB"). Although IRBs are private ethical review bodies often staffed by employ-

93 Wolf et al., supra note 42 , at 246 n. 81 .

94 Based on a search of Westlaw's state and federal judicial database for cases citing 42 C.F.R. $\$ 493.3$ (b) (2).

95 Kathy Todd, Div. of Lab. Servs., Ctrs. for Medicare \& Medicaid Servs., CLIA and Clinical Trials sl. 9 (unpublished visual presentation).

96 Fabsitz et al., supra note 39, at 576.

97 See Federal Policy for the Protection of Human Subjects (“Common Rule”), U.S. DEP'T HEALTH \& HuM. SERvS., http://www.hhs.gov/ohrp/humansubjects/commonrule/index.html (last visited Oct. 5, 2011).

$98 \quad 45$ C.F.R. $\S \S 46.101-46.124$. 
ees of the institution that is conducting the research, ${ }^{99}$ their involvement in research oversight is required by federal regulations. If an IRB restricts the return of research results to participants in an NIHfunded study, this restriction can be characterized as a condition on the receipt of a federal grant. Such restrictions, therefore, count as legally imposed restrictions on the communication of results from federally funded research.

It may raise constitutional issues for the NIH to place speechrestricting conditions on its grants, and this is true even though the $\mathrm{NIH}$ is free to withhold grants altogether. An example helps clarify the potential problem. If it is unconstitutional for the federal government to refuse to let women vote, it is equally unconstitutional for the government to award monetary grants to women on condition that recipients must voluntarily agree not to vote. The "government may not do indirectly what it may not do directly." 100 The notoriously enigmatic $^{101}$ doctrine of unconstitutional conditions ${ }^{102}$ addresses whether particular restrictions on federal spending violate the Constitution. If it would violate the Constitution for the federal government to muzzle investigators directly, then it potentially may violate the Constitution for NIH to condition its grants on oversight by private IRBs that do the day-to-day work of restricting investigators' speech. ${ }^{103}$

Here, it is timely to distinguish Rust $v$. Sullivan, ${ }^{104}$ which upheld a rule that prevented federally funded family planning clinics from offering advice on "abortion as a method of family planning." arose in a medical practice setting, not a research setting, and it is recognized that "speech in the physician-patient relationship may be regulated in a manner that speech outside that context cannot." ${ }^{106}$ Moreover, the Court in Rust did not answer whether "traditional relationships such as that between doctor and patient should enjoy protection under the First Amendment from Government regulation,

See 45 C.F.R. $\S \S 46.103$ (b), 46.107-46.108 (describing IRBs).

Kathleen M. Sullivan, Unconstitutional Conditions, 102 HARV. L. REV. 1413, 1415 (1989).

See id. at 1415-16 (characterizing Supreme Court cases addressing unconstitutional conditions as "a minefield to be traversed gingerly").

102 See id. at 1415 ("The doctrine of unconstitutional conditions holds that government may not grant a benefit on the condition that the beneficiary surrender a constitutional right, even if the government may withhold that benefit altogether.").

It was beyond the scope of this Phase I study to conduct a full analysis of IRB-imposed speech restrictions under the doctrine of unconstitutional conditions; that inquiry is scheduled for a later phase of this ongoing research project. 500 U.S. 173 (1991)

Id. at 180 .

Halberstam, supra note 59, at 846. 
even when subsidized by the Government." ${ }^{107}$ Instead, the decision turned on the fact that the physician was rendering services in a program that offered a narrow, federally defined scope of healthcare services, such that patients would not expect to receive comprehensive medical advice. ${ }^{108}$ Rust did not hold that federal subsidies nullify the First Amendment rights of physicians, and it certainly did not make any statement about how federal subsidies affect the First Amendment rights of researchers. The 2013 decision in Agency for International Development v. Alliance for Open Society, ${ }^{109}$ a case that involved compelled speech rather than speech restrictions, further demonstrates that entities who receive federal funding still have First Amendment rights. ${ }^{110}$

Because IRBs have significant discretion to make decisions about the return of results, there are no explicit substantive rules that mandate how return of results must be handled under the Common Rule. Individual IRBs do, however, refer to a variety of sources for suggestions about ethically appropriate approaches to the return of results. These sources include scholarly bioethical studies and recommendations prepared by governmental advisory bodies and independent working groups. Because these recommendations influence institutional policies and IRB decisions about return of results, Part II reviews several such sources and identifies recurring themes. This Article treats these bioethical recommendations as an indicator of the speech restrictions investigators may face as a result of regulation under the Common Rule.

\section{F. Non-Legal Forms of Restriction}

In addition to the legal restrictions just described, investigators encounter additional constraints on the communication of research results to study participants. These include restrictions imposed by private parties whether as a result of custom, institutional policy, or misunderstanding of the law. For example, some investigators have encountered difficulty publishing their works in academic journals after scientific peer reviewers asserted that the investigators had broken the law by returning results from non-CLIA-certified laboratories

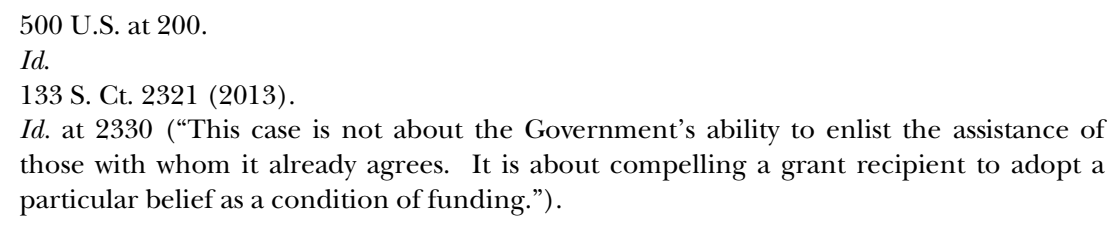


to research participants. Scientific peer reviewers, presumably lacking any training in law or legal process, wield the power to suppress publication of studies by alleging that return of results is illegal. For purposes of First Amendment analysis, these privately imposed sanctions must be distinguished from the legally imposed sanctions described earlier. The U.S. Constitution protects against wrongs imposed by government, but offers no remedy for privately imposed wrongs. There is no constitutional remedy if private parties, such as peer reviewers or academic journal editors, impose hardships on investigators who choose to return results to study participants.

The Constitution does, however, limit the power of state and federal governments to restrict communication, whether through state laws that forbid disclosure of test results to research participants or through federal laws such as the CLIA regulations and the Common Rule. The remainder of this Article explores whether the resulting restrictions on investigators' communication with research participants may violate the First Amendment to the U.S. Constitution.

\section{THE BIOETHICAL VIEW OF SPEECH RESTRICTIONS}

The field of bioethics has never fully engaged with the question of whether it is ethical to regulate or ban communication. The foundational principles of bioethics, such as those set out in the Belmont Report, ${ }^{111}$ unquestionably are broad enough to sustain an inquiry into whether it is appropriate to suppress communication among consenting adults. The absence of a well-developed, systematic bioethical inquiry appears to be the product of neglect or lack of interest, rather than a logical consequence of the ethical principles bioethicists embrace.

The principles of respect for autonomy and respect for persons clearly would support such an inquiry. Speech restrictions may conflict with these principles: restrictions on consensual communications implicate autonomy interests of both the speaker and the listener, ${ }^{112}$ and it potentially displays contempt for persons (rather than

111 See Office of the Sec’y, U.S. Dep’t of Health, Educ. \& Welfare, Belmont Report: Ethical Principles and Guidelines for the Protection of Human Subjects of RESEARCH, 44 Fed. Reg. 23,192 (Apr. 18, 1979) [hereinafter, "BELMONT REPORT"] (setting out broad ethical principles to guide the protection of human research subjects, including beneficence, nonmaleficence, respect for persons and respect for their autonomy, and justice).

112 See 1 NBAC, 1999 REPORT, supra note 47, at 72 (citing Veatch for the idea that the principle of autonomy dictates that subjects have a right to know what has been learned about them) (internal citation omitted); Mark A. Rothstein, Tiered Disclosure Options Promote the 
respect for persons) to presume that they are too credulous or illinformed to make appropriate use of communications provided to them. Decisions to regulate or ban speech are thus rich in potential bioethical issues. Nevertheless, the bioethics literature, with some frequency, recommends speech restrictions as a way to protect human research subjects. For example, the National Bioethics Advisory Commission ("NBAC") has stated,

Experts disagree about whether findings from research should be communicated to subjects, although most do believe that findings should not be conveyed unless they are confirmed and reliable and constitute clinically significant or scientifically relevant information. Those who oppose revealing unconfirmed findings argue that the harms that could result from revealing preliminary data are serious, including anxiety or unnecessary (and possibly harmful) medical interventions. They prefer to avoid such harms by controlling the flow of information to subjects and by limiting communications to those that constitute reliable information. ${ }^{113}$

Note how casually this passage states that "findings should not be conveyed" and discusses "controlling the flow of information to subjects." Contrast NBAC's statement with that of the U.S. Supreme Court, which has described freedom of speech as so important that its "suppression or abridgement ... cannot be regarded otherwise than with grave concern" "114 and also has noted that the "loss of First Amendment freedoms, for even minimal periods of time, unquestionably constitutes irreparable injury."115 As discussed below, many bioethicists treat two major classes of speech restrictions as unobjectionable and even desirable in connection with the return of results: (1) restrictions on the content of what investigators and participants

Autonomy and Well-Being of Research Subjects, 6 AM. J. BiokTHICS 20, 20 (2006) (discussing respect for autonomy as entailing consideration of participants' formulations of benefit, harm, and acceptable risk); Isaac S. Kohane \& Patrick L. Taylor, Multidimensional Results Reporting to Participants in Genomic Studies: Getting It Right, 2 Sci. Translational Med. 1, 1 (2010) (considering the impact of return of results on participants' personhood and autonomy); Sharon F. Terry, The Tension Between Policy and Practice in Returning Research Results and Incidental Findings in Genomic Biobank Research, 13 MINN. J.L. SCI. \& TECH. 691, 698 (2012) (noting that some nations' policies give stronger recognition to the rights of research participants to be informed of their genetic data than do U.S. policies).

1131 NBAC, 1999 REPORT, supra note 47, at 71.

114 Pittsburgh Press Co. v. Pittsburgh Comm'n on Human Relations, 413 U.S. 376, 382 (1973) (quoting Grosjean v. Am. Press Co., 297 U.S. 233, 250 (1936)) (internal quotation marks omitted).

115 Elrod v. Burns, 427 U.S. 347, 373 (1976) (plurality opinion) (citing N.Y. Times Co. v. United States, 403 U.S. 713 (1971)); see also City of Lakewood v. Plain Dealer Publ'g Co., 486 U.S. 750, 758 (1988) (noting that suppressed opportunities for speech are irretrievably lost). 
may discuss, and (2) prior censorship ${ }^{116}$ of investigators' speech-that is, oversight and approval of speech before the speech takes place.

\section{A. Content-Based Restrictions on the Return of Results}

The bioethics community appears generally comfortable with the notion of limiting speech about certain types of research results. There are particular concerns about returning uncertain results, even with appropriate disclaimers. Bookman et al. counsel "extreme caution" $" 117$ in returning results that are preliminary and not validated by other studies. Parker has noted that " $[\mathrm{i}] \mathrm{t}$ is generally, though not uniformly, agreed that unreliable results ought not be offered back to individuals." ${ }^{118}$ Reliability often is framed in terms of the analytical validity of the test and factors that bear on the quality of the laboratory that performed the test, such as the competence of lab personnel and whether controls are in place to avoid mixing up biospecimens collected from different test subjects. CLIA-certified laboratories implement quality standards aimed at avoiding errors and mix-ups, but non-CLIA certified research labs may or may not follow equivalent standards. ${ }^{119}$ When bioethicists recommend suppressing the return results from non-CLIA-certified labs, ${ }^{120}$ this may be for legal reasons (because they believe, rightly or wrongly, that CLIA requires this) or for ethical reasons (because they believe CLIA certification helps protect human research participants by improving the reliability of test

116 Many bioethicists have objected to the use of "censorship" to describe the role ethics review bodies play in overseeing the return of results. The ordinary dictionary meaning of this term merely involves prior review of a proposed communication with the aim of suppressing unacceptable parts of it. See, e.g., Oxford Dictionaries, http://oxforddictionaries.com/us/definition/american_english/censor (defining the verb "censor" as meaning to "examine (a book, movie, etc.) officially and suppress unacceptable parts of it"). By this definition, the term "censorship" fairly describes the role of ethics review bodies in determining which results are unacceptable for return. There is no intent to suggest Orwellian ideological control or political repression.

117 Ebony B. Bookman et al., Reporting Genetic Results in Research Studies: Summary and Recommendations of an NHLBI Working Group, 140 AM. J. MED. GENETICS pt. A, 1033, 1037 (2006).

118 Parker, supra note 20, at 452.

119 See Scott D. Jewell, Perspective on Biorepository Return of Results and Incidental Findings, 13 MINN. J.L. SCI. \& TECH. 655, 665 (2012) (discussing the advantages of CLIA's requirements for proficiency, certification, and quality control in biospecimen repositories that plan to return results).

120 See id. at 663 ("CLIA is clearly a requirement and the process on the engagement of CLIAlicensed assay reporting is well known .....”); Karen J. Maschke, Returning Genetic Research Results: Considerations for Existing No-Return and Future Biobanks, 13 MinN. J.L. SCI. \& TECH. 559, 566-67 (2012) ("Commentators disagree about how to interpret CLIA requirements in the research context.... [But] [s] ome institutions may require genetic research results to be CLIA-validated before they are offered to biospecimen donors."). 
results). Among commentators there is "a near-universal demand for analytic validity as a precondition" for return of results. ${ }^{121}$

Many commentators additionally call for results to be returned only if they have clinical validity - that is, a well-established clinical or reproductive significance. ${ }^{122}$ Even when test results satisfy basic criteria of analytical and clinical validity, many bioethicists feel results should not be returned unless they also have clinical utility or actionability. ${ }^{123}$ If there are no treatments or other measures a person can take to address the risks associated with having a gene mutation, then returning test results would merely imbue the participant with idle knowledge to which there is no practical response.

Restrictions on the return of results may serve important bioethical values, but there are competing values at stake, including values that the First Amendment protects. A free-speech advocate might voice the following concerns: controlling access to information can manipulate people's viewpoints. Apart from forcing participants to walk "a tightrope of terror across the abyss of damnation," 124 informing people that they have problems for which medical science has no solutions could cause them to view healthcare providers as powerless and thus may lower healthcare institutions in the public's esteem. This latter point has not been raised in the bioethics literature, but there are obvious stakeholder advantages in censoring speech about swathes of the genome that reduce our learned intermediaries to tongue-tied stammering, while permitting free discussion of actionable findings - that is, those that showcase healthcare providers' ability to perform miracles. Censoring the return of non-actionable results fosters a point of view that members of the scientific and medical communities are competent and that their expertise can improve people's lives. From a free-speech standpoint, it is disturbing to

121 Wolf, supra note 37, at 446; see also Ingrid A. Holm \& Patrick L. Taylor, The Informed Cohort Oversight Board: From Values to Architecture, 13 MINN. J.L. SCI. \& TECH. 669, 676 (2012) (supporting disclosure of information even if its clinical significance is uncertain but requiring that it be analytically valid).

122 See, e.g., 1 NBAC, 1999 REPORT, supra note 47, at 71; Wolf et al., supra note 42, at 235; see also Maschke, supra note 120, at 559 (citing the fact that most genetic research results have uncertain clinical significance as a reason why many biobanks adopt a "no-return" policy). But see id. at 559-60 (noting that some commentators contend that persons who contribute biospecimens for research should have access to genetic test results even if the information is of uncertain clinical significance).

123 See Wolf et al., supra note 42, at 231 ("Disclosure should occur only when findings are valid and confirmed, have significant health implications, and the health problem can be treated.").

124 SIMPSON, supra note 5 , at 29. 
channel research participants' thoughts toward this (or any other) viewpoint.

Suppressing speech about genes that lack clinical validity and utility also helps keep the genome medical by permitting the public to learn about their genes only in situations where their genes are medical. This fosters a control relationship in which medical institutions remain keepers of the Book of Life, to be discussed only in terms that they define. In the way of all sacred texts, the human genome is susceptible to many meanings, just as the Christian scriptures are variously viewed as a religious text, a work of soaring literary beauty, an anthropological or historical record, and a tract advancing a deeply subversive social program to resist Roman imperialism and empower the meek, unpropertied masses. In the same way, the human genome offers many meanings, not all of them medical.

Banning the return of non-clinically-significant results is a form of censorship that advances a favored point of view that the human genome has one true meaning, which is medical. A public indoctrinated with this point of view may channel its natural curiosity about the human genome into political support for a large federal research budget to fund medical exegesis of the genome. This public may tolerate the cost in time and money of having medical intermediaries order their tests for them and may press their insurers to cover healthcare visits in which people consult with the medical keepers of the human genome (which has one true meaning, which is medical). Suppressing the return of results that lack clinical validity and utility advances a point of view that favors continuance of entrenched healthcare institutional arrangements. The bioethics literature has not explored this possibility, although it would be of obvious concern to a free-speech advocate.

An emerging strand of bioethics does explore the possibility that information may have personal utility or meaning even when it is not actionable in the sense of contributing to improved health outcomes. ${ }^{125}$ Still, not all bioethicists agree that personal meaning supplies a legitimate basis for returning results. ${ }^{126}$ "[T] he literature on

125 See Terry, supra note 112, at 710-11 (discussing the emerging concept of "personal utility"); see also Wolf et al., supra note 42, at $231 \mathrm{n} .80$ (citing various sources for the proposition that results should be returned only if they have clinical utility, but noting that there is debate about what constitutes "clinical utility" with some definitions focusing narrowly on health outcomes while others admit a broader concept that a result has utility if it is important to the individuals and families involved).

126 Fabsitz et al., supra note 39, at 578 (noting that some members of the NHLBI working group dissented from its recommendation that investigators "may choose" to disclose "re- 
whether to return individual research results commonly discourages returning results that lack clinical validity and clinical utility; much of the debate focuses on results whose uncertain meaning and importance is the reason for the research." ${ }^{127}$ It is difficult to find bioethicists who advocate return of all results including those that have uncertain accuracy or significance, ${ }^{128}$ even if appropriate disclaimers are made and even if the research participant desires the information.

Free-speech advocates also might be concerned that restrictions on the return of results inhibit political advocacy by gene-based communities. Sharon Terry notes that granting people access to their genetic test information stimulates curiosity and participation ${ }^{129}$ and it fosters social networks among people who share particular genes. ${ }^{130}$ People who have a gene variant may enjoy associating with other people who carry that same variant even if its medical significance is presently unknown. "[R] esults that are common to the community could challenge the community's sense of who it is. This could be true in an ethnic or geographic community as well as disease-based community." 131

Networks of people who share particular gene variants are a forum for elaborating non-medical meanings of the human genome (for example, if members of a gene-based community discover that they fancy the poetry of Ezra Pound more than other people do). This search for non-medical meaning probably qualifies as harmless fun. Where bioethicists grow concerned is when gene-based communities of laypeople presume to speculate about the genome's medical significance. Terry mentions cases where communities of laypeople have asserted scientifically dubious associations between genes and cystic fibrosis severity or have advocated novel, unsubstantiated treatments or concluded that gene variants cause symptoms that, to date, have no known association with the genes the people have. ${ }^{132}$ Bioethicists and scientists express concern about letting laypeople learn from each other and elaborate community beliefs about the genome, ${ }^{133}$ especially if the beliefs are medical in nature.

sults related to reproductive risks, personal meaning or utility, or health risks" subject to various conditions).

127 See Wolf et al., supra note 42, at 231 (footnote omitted).

128 Wolf, supra note 37 , at 445.

129 Terry, supra note 112 , at 700.

130 Id. at 714 (exploring how test results impact community identity and norms).

131 Id

$132 I d$. at $714-15$.

133 Id. at $715-16$. 
Gene-based communities do not always take medicine into their own hands. Instead, they sometimes become forceful advocates for mainstream research, but even this role can be controversial. Their advocacy efforts may include petitioning the government to make public funds available to study their gene of interest ${ }^{134}$ or developing private resources for research via fundraising, biobanking, and other efforts within the affected community. One community-driven effort of this latter sort began in the late 1980s, when carriers of mutations in the gene associated with Canavan disease worked together to collect biospecimens and funds and enlisted investigators to study the genetic basis of that disease. ${ }^{135}$ A disagreement over the goals of genetic research ultimately devolved into litigation when the investigators patented discoveries against the wishes of the Canavan community, which would have preferred to keep discoveries in the public domain. ${ }^{136}$

The return of results is an intensely private conversation between an investigator and a research subject yet, as Professor Post has noted, " $[\mathrm{T}]$ here is no reason why public opinion might not be formed one conversation at a time." ${ }^{137}$ Individuals who discover they have a gene variant of unknown clinical significance may organize themselves to press for research to clarify its meaning. Yet such communities can form only if people know they possess specific genes. Banning the return of genetic test results that lack clinical significance impedes community formation and stifles this form of community-driven advocacy. Letting people learn which genes they have empowers them to participate more effectively in the national debate about science policy. Suppressing the return of uncertain or non-clinicallysignificant genetic test results has the effect of excluding such people, even if this is not a conscious objective.

134 See generally Rebecca Dresser, When Science Offers Salvation: Patient AdVocacy and RESEARCH ETHICS 5 (2001) ("Today, more than ever, biomedical research is a public affair .... A new breed of patient advocate sits at the table with scientists and policymakers, setting research agendas, planning studies, and considering how study results should affect clinical practice.").

135 See Greenberg v. Miami Children's Hosp., 264 F. Supp. 2d 1064, 1067 (S.D. Fla. 2003) (discussing these efforts). Id.

137 Robert C. Post, Democracy, Expertise, Academic Freedom: A First Amendment JURISPRUDENCE FOR THE MODERN STATE 46 (2012); see also id. (discussing how private discussions between individuals and healthcare providers may cause individuals to support legislation affecting the availability of specific treatments and noting that as long as knowledge is potentially relevant to the formation of public opinion, there is no reason in principle why it should constitutionally matter whether it is distributed to one individual or to a thousand). 
Some in the research community may feel that scientists and medical professionals should decide which parts of the genome are worth studying, without the interference of pesky genetic community advocates petitioning their government to fund a study of this or that gene first. Even if this view has possible merits, it does not comport with our nation's Constitution. Given the limitations of the federal research budget, which genes to study in which order is a matter of public concern. All citizens-even scientifically naïve ones-have the right to petition their government on matters of public concern. ${ }^{138}$

Policies to suppress the return of non-clinically-significant genetic test results implicitly presume that a society can reach optimal decisions about which genes to study if its citizens are kept behind a "veil of ignorance" 139 so that ordinary citizens, not knowing their own genes, are unsure which lines of genetic research would benefit themselves. ${ }^{140}$ Public ignorance, it might be argued, clears the field for dispassionate decision-making by the learned keepers of the human genome. The principle of better policy through public ignorance enjoys perennial support—not specifically here but in many different policy contexts-but it is inconsistent with the First Amendment.

\section{B. Prior Censorship of Return of Results}

Even commentators who support the return of results may call for such conversations to be subject to prior review and regulation by IRBs or other ethics bodies. ${ }^{141}$ Such proposals display a willingness to suppress the speech of investigators whose utterances do not conform to an ethics review board's concept of what is ethical. ${ }^{142}$ A recent example was the 2011 advance notice of proposed rulemaking

See U.S. CONST. amend. I ("Congress shall make no law respecting... . the right of the people peaceably to assemble, and to petition the Government for a redress of grievances.").

139 John RaWls, A TheORY Of JUSTICE $§$ 24, 136-42 (1971).

$140 I d$. at 136-37 ("[Under the veil of ignorance, people] do not know how the various alternatives will affect their own particular case and they are obliged to evaluate principles solely on the basis of general considerations.").

141 See, e.g., Bookman et al., supra note 117, at 1037 ("The decision to report genetic results should not depend solely on the discretion of the investigator, but should include a broader range of perspectives as is found in Institutional Review Boards."); Fabsitz et al., supra note 39, at 575 (calling for IRB review as a condition of discretionary return of results by investigators); Holm \& Taylor, supra note 121, at 672-73 (describing use of an Informed Cohort Oversight Board to oversee return of results); Maschke, supra note 120, at 569-70 (describing various forms of ethics bodies used to oversee return of results from research in biospecimen repositories). 
("ANPRM"), in which HHS proposed that research with biospecimens should receive prior IRB review when results are going to be returned, even if the research otherwise would be "excused" from IRB review under the Common Rule. ${ }^{143}$ This proposal, still not implemented as of this writing, displays a mentality that speech between investigators and participants is intrinsically perilous, triggering a need for prior review. The bioethics literature has not adequately explored whether such speech restrictions are themselves ethically or legally problematic.

In an article that otherwise emphasized respect for participants' personhood and preferences to receive results, Holm and Taylor found it unproblematic to interpose an Informed Cohort Oversight Board ("ICOB") to assess "what information can be effectively communicated in a manner sensitive to subjects' health literacy." ${ }^{144}$ The ICOB, as described, seems very caring and deeply committed to protecting the interests of the research participants. Yet to have an external body, even a benevolent one, censor communications and tailor flows of information to each person's perceived "literacy" has disturbing aspects that elicit concern in other communication contexts. ${ }^{145}$

The literacy of laypeople is not much admired in the bioethics literature: "Participant literacy, or lack thereof, causes a great deal of tension in the system." "A6 "A 1993 study, repeated with the same results in 2002, showed that forty-seven percent of U.S. adults 'lack the literacy skills needed to meet the demands of twenty-first century society." ${ }^{147}$ If these statistics are true, does it follow that there is a bioethical imperative to limit what such people can be told? Speech restrictions seem an ill-fitting response to the problem of public illiteracy. Walling illiterate people off from communication seems unlikely to cure their illiteracy.

143 U.S. Dep't of Health \& Human Servs., Human Subjects Research Protections: Enhancing Protections for Research Subjects and Reducing Burden, Delay, and Ambiguity for Investigators, 76 Fed. Reg. 44,512, 44,514-15 (July 26, 2011) (to be codified at 45 C.F.R. pts. $46,160,164$ and 21 C.F.R. pts. 50, 56).

144 Holm \& Taylor, supra note 121, at 672-73.

145 Indeed, it is alarming to treat any right (even ones that do not relate to communication) as a function of literacy. Thus literacy tests were abolished long ago as a precondition of voter registration, mainly because of their use as an instrument of discrimination. Although literacy no doubt does help make a person a better-informed and more effective voter, illiterate people still have rights among which the right to vote is one of the most important.

146 Terry, supra note 112 , at 709.

147 Id. (citing InSt. OF MEdicine of THE NAT'L ACAD., HEALTh Literacy: A PrEscription to END CONFUSION 146 (Lynn Nielsen-Bohlman et al. eds., 2004)). 


\section{Examples of Proposed Restrictions}

In its 1999 report, NBAC called for IRBs to develop guidelines for return of results and specified that "these guidelines should reflect the presumption that the disclosure of research results to subjects represents an exceptional circumstance." ${ }^{148}$ NBAC recommended that results be returned "only when" the results are "scientifically valid and confirmed," and "have significant implications for the subject's health concerns," and "a course of action to ameliorate those concerns is readily available." ${ }^{49}$ NBAC's "only when" language lends itself to two possible interpretations. One interpretation is that if the conditions are not met, the investigator need not return results (i.e., there is no duty). The alternative interpretation is that if the conditions are not met, the investigator should not return results. This latter interpretation entails content-based suppression of investigators' speech.

As noted earlier, much of the bioethics literature has focused on whether there is a duty for investigators to return research results. Concluding that there is no duty to return results is not the same thing as asserting that there is no right to do so. Unfortunately, the literature often fails to specify whether it is discussing the duty or the right to return results. Statements like NBAC's recommendation to return results "only when" ${ }^{150}$ certain conditions are met have led many IRBs and commentators to conclude that speech bans may be warranted when those conditions are not met. The notion that speech bans are appropriate implicitly presumes that there is no right for investigators and research subjects to engage in such communication.

A 2008 article by Wolf et al. similarly seems to advocate contentbased restrictions on the return of research results. ${ }^{151}$ This article delineates "when incidental findings should be returned, may be returned, and should not be returned." ${ }^{152}$ It recommends that a "[r] esearcher should not disclose IFs offering unlikely net benefit from

1 NBAC, 1999 REPORT, supra note 47, at 72. But see Terry, supra note 112, at 726 (suggesting that NBAC's view may now be out-of-date, particularly in view of the quality and relevance of data from whole genome sequencing, which requires clear disclosure policies). I NBAC, 1999 REPORT, supra note 47, at 72. Id.

Wolf et al., supra note 42, at 219, 235 (stating, in the 2008 study's recommendations, "Do not disclose" to research participants "information revealing a condition that is not likely to be of serious health or reproductive importance" or "information whose likely health or reproductive importance cannot be ascertained").

152 Wolf, supra note 37, at 441 (summarizing the findings of the 2008 study by Wolf et al., supra note 42$)$. 
the participant's perspective, including 'information whose likely health or reproductive importance cannot be ascertained." "153 The use of "should not" rather than "need not" suggests that this article is not merely noting the absence of a duty to discuss results that lack clinical or reproductive significance. It appears to be advocating content-based restrictions on investigators' speech. On close reading, however, the article acknowledges that " $[\mathrm{t}]$ here is a distinct debate on returning research information at the request of research participants." 154 Thus, the article may not have intended to express any opinion about the investigator's right to discuss results with a willing research participant. Yet the "should not" language does seem to contemplate banning or restricting certain types of speech.

In an influential 2006 article $^{155}$ that reported recommendations of the NHLBI Working Group on Reporting Genetic Results in Research Studies, Bookman et al. discussed whether (and when) investigators have a duty to offer the return of research results. ${ }^{156}$ This article also noted that there is a "strong voice that supports the right of participants to receive results that may be clinically useful." ${ }^{\text {157 }}$ This discussion of participants' rights and investigators' duties did not, however, explore investigators' rights to communicate results to participants who wish to receive them.

A separate NHLBI-sponsored working group paper in 2010 found a duty to return results that have "important health implications" when the risks are "established and substantial" and when the results are "actionable" in the sense that there are established therapies or preventive actions that could improve the clinical outcome. ${ }^{158}$ This duty would exist only if " $[\mathrm{t}]$ he test is analytically valid, and the disclosure plan complies with all applicable laws" and if the subject has consented to the return of results. ${ }^{159}$ In situations where there is no duty to return results, the NHLBI paper allowed that an investigator "may choose" to return results if "all of the following apply":

a. The investigator has concluded that the potential benefits of disclosure outweigh the risks from the participant's perspective.

b. The investigator's IRB has approved the disclosure plan.

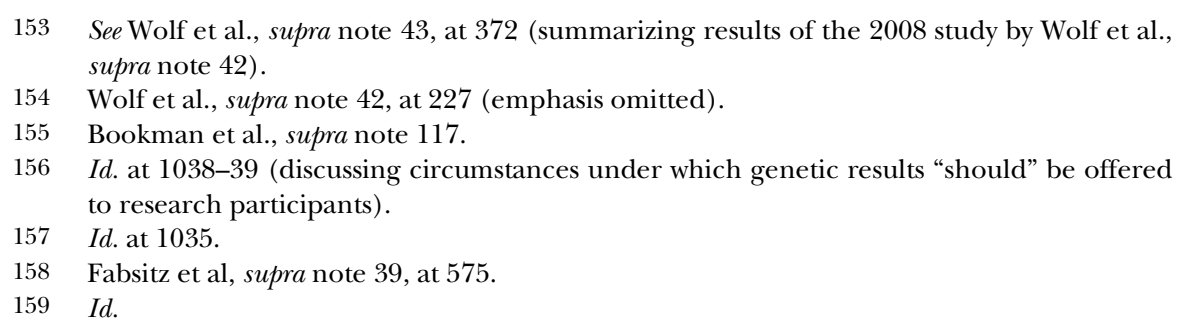


c. The test is analytically valid and the disclosure plan complies with all applicable laws.

d. [and the participant has consented to the return of information]. ${ }^{160}$

These conditions still place significant burdens on the return of results. For example, the return of results would be subject to prior IRB review, and investigators and participants would not be permitted to discuss the results of tests having uncertain analytical validity even if the uncertainty is forthrightly disclosed. The NHLBI paper is somewhat unusual, however, in the breadth of information it would allow investigators to return. ${ }^{161}$ Subject to the conditions just listed, it would grant them discretion to return "results related to reproductive risks, personal meaning or utility, or health risks," although some members of the NHLBI working group dissented on the matter of whether personal meaning to the participant is a proper basis for return. ${ }^{162}$

It is clear that bioethical perspectives on the return of results disagree on many nuances and particulars, but the bioethical literature displays fairly broad support for the following proposition: speech restrictions that suppress the return of results may be justified when the findings (1) are uncertain or are of questionable analytical validity, ${ }^{163}$ (2) lack a well-established clinical validity or reproductive significance, ${ }^{164}$ or (3) lack clinical utility/actionability. ${ }^{165}$ To facilitate fur-

$160 \quad I d$. at $577-78$. The bracketed passage here summarizes a longer discussion in the original.

161 Id.; see also Holm \& Taylor, supra note 121, at 671 (arguing that the personal meaning of genomic information and patient preferences should inform decisions about return of results). But see id. at 675 (discussing efforts to address the fact that within The Gene Partnership, the primary results eligible for potential disclosure would not be known clinical variants incidentally discovered, but instead would be new and uncertain discoveries-novel variants, or novel understandings).

162 Fabsitz et al., supra note 39, at 578.

163 See, e.g., 1 NBAC, 1999 REPORT, supra note 47, at 71 ("[M] ost [experts] believe that findings should not be conveyed unless they are confirmed and reliable and constitute clinically significant or scientifically relevant information."); Parker, supra note 20, at 452 ("It is generally, though not uniformly, agreed that unreliable results ought not be offered back to individuals."); Wolf, supra note 37, at 446 ("[W]e see a near-universal demand for analytical validity as a precondition for informational return."); see also Holm \& Taylor, supra note 121, at 676 (supporting disclosure of information even if its clinical significance is uncertain but requiring that it be analytically valid).

164 See, e.g., 1 NBAC, 1999 REPORT, supra note 47, at 71; Wolf et al., supra note 42, at 235 (summarizing various recommendations); see also Maschke, supra note 120, at 559 (citing the fact that most genetic research results have uncertain clinical significance as a reason why many biobanks adopt a "no-return" policy). But see id. at 559-60 (noting that some commentators contend that persons who contribute biospecimens for research should have access to genetic test results even if the information is of uncertain clinical significance).

165 See Wolf et al., supra note 42, at 231. 
ther analysis of this proposition, this Article will refer to it as the "cautious" approach insofar as it seeks to restrict the communication of genetic information to the individuals whose genomes are involved.

\section{Ethical Justifications for Suppressing the Return of Results}

Bioethicists cite various concerns that justify restricting the return of results. Table 1 shows a sampling of these justifications. Some ethicists challenge whether returning results has value as a form of communication. Other ethicists are concerned that returning results may inflict various types of harm on participants and, potentially, on their families and genetically similar communities. There also is concern that returning results may cause broader social and economic harms to the public.

\section{TABLE 1}

ETHICAL JUSTIFICATIONS FOR RESTRICTING THE RETURN OF RESULTS

\section{Challenges to THE VAlue of THE Communication}

1. Individual findings are not "information" worth communicating. " $[\mathrm{P}]$ reliminary results do not yet constitute 'information' since 'until an initial finding is confirmed, there is no reliable information' to communicate to subjects ....",166

2. Returning results is ineffective: even if participants are not harmed by it, they may fail to gain any benefits. Returning results may fail to help people manage their health risks, because genetic risk is not an effective motivator of behavioral change. ${ }^{167}$

\section{CONCERNS ABOUT LISTENER VULNERABILITY}

3. Returning results may expose participants to anxiety. Returning results could cause participants to experience anxiety about their test results. ${ }^{168}$ In sit-

166 See 1 NBAC, 1999 REPORT, supra note 47, at 71-72 (citing Charles R. MacKay, Ethical Issues in Research Design and Conduct: Developing a Test to Detect Carriers of Huntington's Disease, 6 IRB 1, 3 (1984)).

167 Parker, supra note 20, at 468-69.

1681 NBAC, 1999 REPORT, supra note 47, at 71; Parker, supra note 20, at 470 (noting concerns about psychological impacts); Terry, supra note 112, at 713 (noting anxiety associ- 
uations where people's biospecimens have been studied without their consent, returning results could further upset them by making them aware that their specimens were used in research without their knowledge. ${ }^{169}$

4. Participants may misunderstand their results. There is thought to be a high risk that participants will misconstrue the meaning of their genetic test results. ${ }^{170}$ Laypeople may fail to appreciate the uncertainty of research results and are prone to therapeutic misconception (the belief that research results are more useful for clinical purposes than the results actually are). ${ }^{171}$ "[E]ven ... confirmed findings may have some unforeseen limitations." "172

5. Returning results may cause participants to make bad healthcare decisions that harm them. Returning results could cause unnecessary (and possibly harmful) medical interventions. ${ }^{173}$

6. Returning results exposes participants to the risk of stigmatization or discrimination. Telling people their test results may place them at risk of stigmatization or discrimination in employment or insurance. ${ }^{174}$ Communicating genetic information to one individual may have impacts on genetically similar family members and population groups, possibly subjecting them to adverse impacts. ${ }^{175}$

7. Participants' preferences to receive return of results may not reflect what they actually want. Participants' expressed preferences to receive their test results may be unreliable, ${ }^{176}$ unstable over time, ${ }^{177}$ based on false beliefs ${ }^{178}$ or

ated with learning about risks, but indicating that some studies suggest that this effect is less than previously thought).

169 Maschke, supra note 120, at 563.

170 See Holm \& Taylor, supra note 121, at 670 (" $[\mathrm{C}]$ ommunicating genomic research results has historically been opposed, by some, based on an assumption that therapeutic misconceptions are inevitable, that harm necessarily flows from a misconception and is unpreventable and incurable, and that such harm necessarily outweighs any potential benefit, regardless of how benefit might be conceived or measured." (citing Kohane \& Taylor, supra note 112, at 1-2)).

171 See, e.g., Terry, supra note 112, 720-21; see also id. at 709 (discussing a study that found that forty-seven percent of people lack the basic scientific "literacy" necessary for life in a twenty-first-century society).

172 See 1 NBAC, 1999 RePORT, supra note 47, at 71-72 (quoting MacKay, supra note 166, at 3) (internal quotation marks omitted).

173 Id. at 71.

174 Terry, supra note 112, at 712.

1751 NBAC, 1999 REPORT, supra note 47, at 72-73.

176 Parker, supra note 20, at 475-477. 
misunderstandings about the uncertainty of results, ${ }^{179}$ or may be irrational and ill-informed. ${ }^{180}$

\section{Concerns About BroAder ECONOMIC ANd SOCIAL HARMS TO THE PUbliC}

8. Returning results may cause participants to over-consume follow-up healthcare services. Returning results creates increased demand for follow-up care and places burdens on scarce healthcare resources as participants seek to clarify the impact of their genes. ${ }^{181}$

9. The cost of returning results may harm the research enterprise. The high cost of returning results could reduce the availability of funds for research. ${ }^{182}$ Note, however, that much of the perceived cost comes from the cautious view's insistence that only high-quality, confirmed results should be returned. This insistence entails significant investment to enhance certainty prior to return of results.

10. Participants may corrupt genetic understanding as they attempt to decipher the meaning of their test results. After receiving results, participants may draw scientifically invalid conclusions based on blogs and other postings in communities formed by laypeople who share particular genes. ${ }^{183}$ Community beliefs may supplant valid science and propagate inaccurate "disease legends." 184

The concerns listed in Table 1 may supply ethical justification for suppressing the return of results, assuming of course that there is no ethical objection to the paternalism implicit in keeping participants uninformed for their own good. ${ }^{185}$ Yet ethical justification and legal justification are two different things. Even if speech restrictions are ethically justified, it may not be constitutional to enact speech restrictions into law. For example, impolite remarks can be highly un-

\footnotetext{
177 See id. at 474; see also Terry, supra note 112, at 706 ("[P]ersonal preferences can change throughout the life course due to many circumstances."); $f$. Holm \& Taylor, supra note 121, at 676 ("[Some commentators express] skepticism about whether preferences are actually durable, known by, and ascertainable from participants.").

178 See Parker, supra note 20, at 461.

179 See id. at 463.

180 See id. at 466.

181 See Terry, supra note 112 , at 723.

182 See Parker, supra note 20, at 467 ; $f$. Jewell, supra note 119, at 664.

183 See Terry, supra note 112, at 715.

$184 I d$. at 714 (internal quotation marks omitted).

185 See Parker, supra note 20, at 480 (“[P] aternalistic understanding of individuals' well-being can be justified in the context of research, even genomic research.”).
} 
ethical, but a law banning impolite speech almost surely would violate the First Amendment. If the speech restrictions bioethicists recommend were imposed by force of law, it is not clear they would be constitutional. The remainder of this Article explores whether laws and regulations restricting the return of results can be legally, as well as ethically, justified.

\section{THE LEgAL VIEW OF SPEECH RESTRICTIONS}

The field of law has had a sustained engagement with problems related to the suppression of free speech. Use of the First Amendment to protect free speech is of relatively recent origin, tracing to a series of opinions Justice Oliver Wendell Holmes wrote in 1919. ${ }^{186}$ Courts have subsequently decided many cases involving First Amendment protection of speech and there is a large scholarly literature on the subject.

The fact that bioethicists sometimes espouse speech restrictions as a tool of human-subject protection may reflect historical factors. First Amendment doctrine continued to evolve after the 1970s, but modern research bioethics rests heavily on concepts and principles elaborated in the 1970 s era. The National Research Act of $1974^{187}$ established a National Commission ${ }^{188}$ that oversaw development of the Belmont Report, ${ }^{189}$ published in 1979, which identifies ethical principles that continue to animate research bioethics. In 1978, this commission also enunciated a set of regulatory recommendations to be reflected in the Common Rule. ${ }^{190}$ For much of the twentieth century,

186 Robert Post, Reconciling Theory and Doctrine in First Amendment Jurisprudence, 88 CALIF. L. REv. 2353, 2356-59 (2000) (discussing Justice Holmes's development of First Amendment law in Schenck v. United States, 249 U.S. 47 (1919), and Abrams v. United States, 50 U.S. 616, 630 (1919) (Holmes, J., dissenting)).

187 National Research Act of 1974 (National Research Service Award Act of 1974), Pub. L. No. 93-348, 88 Stat. 342 (codified as amended in scattered sections of 42 U.S.C.).

188 See Pub. L. 93-348, 88 Stat. 342, § 201 (enacting 42 U.S.C. $\$ 2891-1$, the precursor of today's 42 U.S.C. $\$ 300 \mathrm{v}-1$, creating the National Commission and describing its role in developing substantive standards of human subject protection); U.S. DEP'T OF HEALTH, Educ. \& Welfare, Protection of Human Subjects: InStitutional Review Boards: REPORT AND RECOMMENDATIONS OF THE NATIONAL COMMISSION FOR THE PROTECTION OF Human Subjects of Biomedical and Behavioral Research, 43 Fed. Reg. 56,174 (Nov. 30, 1978) [hereinafter HEW, 1978 REPORT] (discussing the National Commission and reporting its findings).

189 BELMONT REPORT, supra note 111, at 23,192.

190 HEW, 1978 REPORT, supra note 188, at 56,175-83; see also 42 U.S.C. $\$ 300 \mathrm{v}-1$ (b) (requiring the Secretary of Health and Human Services to consider and respond to recommendations of the National Commission and a successor commission when establishing the Common Rule's substantive standards of human subject protection). 
including well into the 1970 s as this work was underway, the Supreme Court viewed health care as having a special status that justified heavy regulation, including speech restrictions, to promote health and safety interests: "When public and private actors invoked health concerns to justify their conduct, the Court often expressed less skepticism than when other reasons were invoked for public and private conduct." ${ }^{191}$

This special status of health care eroded in subsequent decades. ${ }^{192}$ A crucial event in its erosion was the emergence of the commercial speech doctrine, which limits the regulation of speech even in healthrelated contexts. The Supreme Court enunciated this doctrine in a 1976 case, Virginia State Board of Pharmacy v. Virginia Citizens Consumer Council, Inc. ${ }^{193}$ That decision struck down a state law that prohibited advertising of prescription drug prices, and the doctrine continued to evolve from that starting point. ${ }^{194}$ The foundations of modern human-subject protections trace back to an era when policymakers presumed it was legally unproblematic to suppress speech to promote health and safety objectives. That presumption has changed, but the field of bioethics has failed to change with it. The bioethical debate about return of results at times seems out of touch with current First Amendment realities.

\section{A. Brief Summary of the First Amendment Framework}

First Amendment doctrine recognizes three categories of speech, with the degree of First Amendment protection a particular communication receives depending on which category of speech is involved. The first category ("regulable speech") includes various types of communication that lie largely outside of First Amendment protection and can be regulated by the government, whether through state or federal statutes and regulations or through state common law (e.g., tort lawsuits). Scholars disagree about the breadth of speech

191 David Orentlicher, The Commercial Speech Doctrine in Health Regulation: The Clash Between the Public Interest in a Robust First Amendment and the Public Interest in Effective Protection from Harm, 37 AM. J.L. \& MED. 299, 300 (2012).

192 See id. at 302 (noting that the Supreme Court and lower federal courts are increasingly willing to challenge public health justifications for limitations on individual liberties).

193425 U.S. 748,770 (1976).

194 See Coleen Klasmeier \& Martin Redish, Off-Label Prescription Advertising, the FDA and the First Amendment: A Study in the Values of Commercial Speech Protection, 37 AM. J.L. \& MED. 315, 339-41 (2012) (discussing the strengthening of commercial speech doctrine in the years after 1976). 
activity that is regulable. ${ }^{195}$ This disagreement is largely immaterial to this discussion because common candidates for regulable speechthings like "defamation, incitement, obscenity, and pornography produced with real children" ${ }^{" 196}$ - obviously have nothing to do with the return of genetic test results. Two categories of speech regulation are, however, potentially relevant to this discussion and will be examined in greater detail below. These are: (1) professional speechthat is, the speech that lawyers, doctors, and other licensed professionals provide to clients and patients in the course of providing professional services, ${ }^{197}$ and (2) speech regulation-particularly, regulation of health claims-that occurs pursuant to consumer-product safety and other health and safety regulations. ${ }^{198}$

The second category is commercial speech, which enjoys a measure of First Amendment protection ${ }^{199}$ although the government has a constrained (but still considerable) power to regulate it. ${ }^{200}$ Commercial speech has been described as "speech proposing a commercial transaction" ${ }^{201}$ or "speech ... related to the economic interests of the

195 See, e.g., Barry P. McDonald, Government Regulation or Other "Abridgements" of Scientific Research: The Proper Scope of Judicial Review Under the First Amendment, 54 EMORY L.J. 979, 1009 (2005) ("The Court has generally taken an 'all-inclusive' approach ... asserting that all speech receives First Amendment protection unless it falls with[in] certain narrow categories of expression ...."); see also, e.g., Eugene Volokh, The Trouble with "Public Discourse" as a Limitation on Free Speech Rights, 97 VA. L. REV. 567, 584, 591 (2011) (noting that the "all-inclusive approach" (or, more precisely, the "presumptive all-inclusive approach") is the approach the Court has generally set forth, though with some exceptions, and noting that, at times, the exceptions are over-counted by separately counting various legal scenarios that all share a common feature, e.g., that there is no constitutional protection of false statements of fact). But see James Weinstein, Participatory Democracy as the Central Value of American Free Speech Doctrine, 97 VA. L. REv. 491, 492 (2011) ("[H]ighly protected speech is the exception, with most other speech being regulable because of its content with no discernible First Amendment constraint ....").

196 Ashcroft v. Free Speech Coal., 535 U.S. 234, 246 (2002).

197 See Post, supra note 56, at 947-48 (discussing the regulation of speech by physicians and dentists).

198 See Orentlicher, supra note 191, at 299 (noting that the government historically was granted more leeway to regulate speech for the purpose of safeguarding public health than for advancing other state interests).

199 See Bd. of Trs. v. Fox, 492 U.S. 469, 477 (1989) (“[C]ommercial speech [enjoys] a limited measure of protection, commensurate with its subordinate positions in the scale of First Amendment values...." (quoting Ohralik v. Ohio State Bar Ass'n, 436 U.S. 447, 456 (1978)) (internal quotation marks omitted)).

200 See, e.g., Thompson v. W. States Med. Ctr., 535 U.S. 357, 367 (2002) (“Although commercial speech is protected by the First Amendment, not all regulation of such speech is unconstitutional."); see also Robert Post, The Constitutional Status of Commercial Speech, 48 UCLA L. REV. 1, 2-3 (2000) (noting the subordinate status of commercial speech and the government's ability to regulate it).

201 Bolger v. Youngs Drug Prods. Corp., 463 U.S. 60, 64 (1983) (quoting Ohralik, 436 U.S. at 455-56) (internal quotation marks omitted); Zauderer v. Office of Disciplinary Counsel, 
speaker and its audience, ${ }^{202}$ and it includes such things as advertising, ${ }^{203}$ creating and disseminating health records as part of a datamining business, ${ }^{204}$ and making health claims about a product (for example, claiming that a vitamin prevents cancer or reduces the risk of neural tube defects). ${ }^{205}$

The third category is pure speech $^{206}$ (also called noncommercial speech, core First Amendment speech, or fully protected speech) that receives the most robust constitutional protection. Scholars disagree about the precise scope of fully protected speech, ${ }^{207}$ but there is general agreement that it includes, at the very least, such things as political speech-“[d]iscussion of public issues" ${ }^{\text {"208 }}$ and the "unfettered interchange of ideas for the bringing about of political and social changes desired by the people" ${ }^{209}$ - as well as artistic expression and scholarly and scientific debate. ${ }^{210}$

Concerns raised earlier in this Article hint at the possibility that the return of results may include elements of core First Amendment

471 U.S. 626, 637 (1985) (quoting Ohralik, 436 U.S. at 455-56) (internal quotation marks omitted).

202 Cent. Hudson Gas \& Elec. v. Pub. Serv. Comm'n., 447 U.S. 557, 561 (1980) (citing Va. State Bd. of Pharmacy v. Va. Citizens Consumer Council, Inc., 425 U.S. 748, 762 (1976)).

204 See Sorrell v. IMS Health Inc., 131 S. Ct. 2653, 2667 (2011) (“[T]he creation and dissemination of information are speech within the meaning of the First Amendment.").

205 See, e.g., Pearson v. Shalala (Pearson I), 164 F.3d 650, 658 (D.C. Cir. 1999) (applying commercial speech doctrine in a First Amendment challenge to FDA restrictions on health claims that dietary supplements and food fiber can reduce the risks of certain cancers and neural tube defects); Whitaker v. Thompson, 248 F. Supp. 2d 1, 2, 7 (D.D.C. 2002) (applying commercial speech doctrine in a First Amendment challenge to FDA restrictions on claims that anti-oxidants reduce the risk of cancer); Alliance for Natural Health US v. Sebelius, 714 F. Supp. 2d 48, 60-61 (D.D.C. 2010) (applying commercial speech doctrine in a First Amendment challenge to FDA restrictions on claims concerning selenium and cancer); Alliance for Natural Health US v. Sebelius, 786 F. Supp. 2d 1, 4 (D.D.C. 2011) (applying commercial speech doctrine in a challenge to FDA restrictions on claims that vitamins $\mathrm{C}$ and $\mathrm{E}$ prevent cancer).

206 See Wash. Legal Found. v. Friedman (WLF I), 13 F. Supp. 2d 51, 60 (D.D.C. 1998) (contrasting the First Amendment frameworks for pure speech and commercial speech), vacated on other grounds, Wash. Legal Found. v. Henney, 202 F.3d 331 (D.C. Cir. 2000).

207 See, e.g., Volokh, supra note 195, at 567 (arguing that labels such as "public discourse" and "speech on matters of public concern" are not adequate for delimiting the range of speech that is protected by the First Amendment); Martin H. Redish, The Value of Free Speech, 130 U. PA. L. Rev. 591, 625-29 (1982) (exploring the normative position that all human expression should receive First Amendment protection).

208 See Buckley v. Valeo, 424 U.S. 1, 14 (1976).

209 Id. (quoting Roth v. United States, 354 U.S. 476, 484 (1957)) (internal quotation marks omitted).

210 See WLF I, 13 F. Supp. 2d at 59 (noting that scientific and academic speech is entitled to the highest level of First Amendment protection). 
speech. ${ }^{211}$ While this may be true, the analysis that follows will rely primarily on the commercial speech doctrine. This reflects a pragmatic choice about study design: the goal here is to test whether the First Amendment protects the communication that occurs when an investigator returns results to a research participant. The more rigorous test of this hypothesis is to analyze the return of results under the assumption that it is merely commercial speech, if indeed it is constitutionally protected at all. If the commercial speech doctrine protects this communication, then it would be all the more protected if return of results were conceived as core First Amendment speech. The reliance on commercial speech analysis is thus the more stringent and skeptical way to test this Article's hypothesis.

\section{B. Protection of Commercial Speech}

Until 1976, the Supreme Court interpreted the First Amendment as placing no constraint on the government's ability to regulate commercial speech. $^{212}$ Since that time, commercial speech has received a measure of First Amendment protection. Early commercial speech cases referred to this as a "limited measure of protection" ${ }^{213}$ to emphasize that commercial speech holds a "subordinate position in the scale of First Amendment values." ${ }^{214}$ In a recent case, Sorrell $v$. IMS Health Inc., ${ }^{215}$ the Supreme Court at times seemed to suggest that commercial speech has parity with pure (noncommercial) speech but, in fact, the Court did not announce a new standard for protecting commercial speech and ultimately decided the case using the same analytical framework it has been using in commercial speech cases for over thirty years. This framework is called the Central Hudson test, ${ }^{216}$ named for the 1980 case Central Hudson Gas $\mathcal{E}$ Electric Corp.

211 See discussion supra notes 18-36 and notes 123-37 and accompanying text.

212 See Va. State Bd. of Pharmacy v. Va. Citizens Consumer Council, Inc., 425 U.S. 748,762

(1976) (recognizing a degree of constitutional protection for commercial speech); see also Post, supra note 200, at 2.

213 Bd. of Trs. v. Fox, 492 U.S. 469, 477 (1989) (emphasis added) (“[C]ommercial speech [enjoys] a limited measure of protection, commensurate with its subordinate position in the scale of First Amendment values ...." (quoting Ohralik v. Ohio State Bar Ass'n, 436 U.S. $447,456(1978)))$.

215131 S. Ct. 2653 (2011).

216 Id. at 2667-68 (deciding the case under standards enunciated in Cenral. Hudson Gas $\mathcal{E}$ Electric Corp. v. Public Service Commission, 447 U.S. 557, 566 (1980), which are associated with commercial speech cases and are less strict than the tests courts apply in cases involving core First Amendment speech); see also id. at 2667 ("[T]he outcome is the same whether a special commercial speech inquiry or a stricter form of judicial scrutiny is applied."). 
v. Public Service Commission of New York ${ }^{217}$ that first enunciated it. After courts determine that a communication is commercial speech, they use the four-step Central Hudson test to analyze whether laws regulating that speech are constitutional.

At Step One, courts ask whether the speech is non-misleading and concerns lawful activity. ${ }^{218}$ If the speech is found to be misleading or relates to an illegal activity, that is the end of the analysis: the speech is not entitled to any constitutional protection and the government may regulate it. ${ }^{219}$ If, on the other hand, the speech is non-misleading and is not about an unlawful activity, the speech is eligible for constitutional protection. ${ }^{220}$ The government still may be able to regulate the speech, but the regulations must satisfy three constraints. The remainder of the Central Hudson test focuses not on the speech, but on the specific regulation that is the subject of the First Amendment challenge. Steps Two-Four of the Central Hudson test check that the regulation satisfies each of the three constraints.

At Step Two, courts ask whether the government's asserted interest in regulating the speech is "substantial." ${ }^{221}$ Unless the government asserts an important reason for regulating commercial speech, courts will find the regulation unconstitutional at this step in the analysis.

Assuming the government has enunciated a substantial interest that it is trying to protect, courts move to Step Three, which asks whether the regulation directly advances that interest. ${ }^{222}$ If regulating commercial speech only will have a tenuous or indirect impact on the problem the government is trying to solve, courts will find the regulation unconstitutional at this step in the analysis.

Finally, if the regulation passed the earlier tests, courts move to Step Four and ask whether the regulation is more extensive than is necessary to serve the interest. ${ }^{223}$ For example, did the regulation ban speech altogether when requiring a warning or disclosure would have solved the problem? Even if the government is trying to protect an important interest, and even if the regulation contributes in a positive way to the government's objective, the regulation still will be uncon-

217 See Cent. Hudson, 447 U.S. at 563-64, 566 (striking down regulations that banned promotional advertising by utility companies even though the state claimed that the ban would encourage energy conservation and prevent inequities in utility rates).

Id. at 566 .

$I d$. at 563-64.

$I d$. at 564-65.

Id. at 566 .

$I d$.

Id. 
stitutional if the regulation has a more draconian impact on free speech than was necessary.

This overview of the Central Hudson test raises a number of practical questions in the context of return of results. For example, what does it mean for speech to be misleading? Does returning a genetic test result to a person who failed eighth-grade biology count as misleading speech? If the CLIA regulations require labs to be CLIAcertified in order to return results, would returning results from a non-CLIA-certified lab be speech "related to unlawful activity"? ${ }^{224}$ What types of government interests count as substantial? What does it mean for a regulation to advance the government's interest directly and be no more extensive than necessary? The best way to answer these questions is with examples of how the Central Hudson test has been applied in relevant court cases that raised issues similar to those encountered in returning results.

Before turning to that task, Table 2 shows the range of outcomes that can occur under this test. The Central Hudson test grants the government considerable leeway to regulate commercial speech. The government can, for example, require speakers to make disclosures or it can impose prior restraints on what can be communicated (for example, by requiring statements to be backed by scientific evidence). ${ }^{225}$ A well-designed, well-justified regulation of commercial speech can survive the four-factor analysis and be found constitutional. As the Court noted in Sorrell v. IMS Health, "the government's legitimate interest in protecting consumers from commercial harms explains why commercial speech can be subject to greater governmental regulation than noncommercial [pure] speech."226 On the other hand, regulations that are poorly designed or inadequately justified will fail the test and be deemed unconstitutional. Thus, commercial speech may turn out to be regulable, if the regulation satisfies the Central Hudson criteria.

Id. at 564

See Post, supra note 200, at 1 ("[T] he state can compel disclosures, impose overbroad regulations, and establish prior restraints within the domain of commercial speech ....").

226 Sorrell v. IMS Health Inc., 131 S. Ct. 2653, 2672 (2011) (quoting Cincinnati v. Discovery Network Inc., 507 U.S. 410, 426 (1993)) (internal quotation marks omitted). 
TABLE 2

Possible Outcomes Under the CENTRAL HudSON TEST

\begin{tabular}{|l|l|}
\hline $\begin{array}{c}\text { CHARACTERISTICS OF THE } \\
\text { COMMERCIAL SPEECH }\end{array}$ & $\begin{array}{l}\text { MAY THE GOVERNMENT REGULATE THE } \\
\text { SPEECH? }\end{array}$ \\
\hline \hline $\begin{array}{l}\text { Commercial speech that is } \\
\text { misleading or related to an } \\
\text { unlawful activity }\end{array}$ & $\begin{array}{l}\text { Yes. Regulations that restrict this speech } \\
\text { are constitutional. This speech is ineligible } \\
\text { for constitutional protection and is regula- } \\
\text { ble speech. }\end{array}$ \\
\hline $\begin{array}{l}\text { Commercial speech that is } \\
\text { neither misleading nor related } \\
\text { to an unlawful activity }\end{array}$ & $\begin{array}{l}\text { Yes, if the regulation meets certain criteria. This } \\
\text { speech is eligible for constitutional protec- } \\
\text { tion but it nevertheless can be regulated } \\
\text { provided that the government has a substan- } \\
\text { tial interest and the regulation directly ad- } \\
\text { vances that interest and is no more exten- } \\
\text { sive than it needs to be. Regulations that } \\
\text { meet these criteria are constitutional and } \\
\text { the commercial speech in question is regu- } \\
\text { lable. }\end{array}$ \\
$\begin{array}{l}\text { No, if the regulation fails to meet the criteria. } \\
\text { This speech is eligible for constitutional } \\
\text { protection, and regulations that fail to } \\
\text { meet the criteria just described are uncon- } \\
\text { stitutional. The speech is protected by the } \\
\text { First Amendment. }\end{array}$ \\
\hline
\end{tabular}

IV. IS RETURN OF RESUlts PROTECTED AS COMMERCIAL SPEECH?

Investigators who return genetic test results do so gratis for the perceived benefit of research participants and, in many cases, the investigators are not even physicians who could supply the follow-up care that the participants may seek after learning their genetic test results. Part IV.A explains why the return of results nevertheless has attributes of commercial speech. Then, Parts IV.B-IV.D draw on relevant case law to apply the various steps of Central Hudson to the return of results. Finally, Part IV.E explores whether the concept of regula- 
ble professional speech might justify placing restrictions on the return of results and concludes that it does not.

\section{A. Why Return of Results Can Be Characterized as Commercial Speech}

If the return of results is in the nature of noncommercial (pure) speech, then it would be very hard to justify the restrictions that law and bioethics place on investigators' communications with research participants. The more stringent test of whether such restrictions are constitutional is to proceed under the hypothesis that return of results may merely be commercial speech. This characterization is plausible for reasons discussed below.

Return of results has promotional aspects. Returning results promotes a commercial transaction. The commercial transaction is the research itself or, more specifically, the procurement of a critical input (research participants) for the research. There is considerable evidence suggesting that people's willingness to contribute their biospecimens or otherwise volunteer for genetic research depends on whether they will receive return of results. ${ }^{227}$ One survey found that "[t]he most influential factor affecting the respondent's willingness to participate in the study seemed to be the offer of individualized results. ${ }^{228}$ Restricting investigators' ability to return research results potentially interferes with their ability to procure raw materials, such as biospecimens, for research. Washington Legal Foundation v. Friedman defined advertising as communications "emphasizing desirable qualities so as to arouse a desire to buy or patronize." ${ }^{229}$ Returning results emphasizes an aspect of research that many prospective participants find desirable: the chance to learn about the genome including one's own. Such considerations need not be the sole motive, in order for return of results to have a promotional effect.

A related question is whether federally funded genetic research is "commercial." Modern courts characterize research as a commercial activity unless it is "solely for amusement, to satisfy idle curiosity, or for strictly philosophical inquiry" ${ }^{230}$ - a standard that little if any NIH-

\footnotetext{
227 See Parker, supra note 20, at 471-72 (discussing various studies of participants' preferences concerning return of results and whether return of results influenced their willingness to volunteer for research); Terry, supra note 112, at 708-09 (noting that one study found that people's willingness to contribute to a research biobank was tied to there being a binding agreement addressing return of results).

228 Parker, supra note 20, at 472.

229 Wash. Legal Found. v. Friedman (WLF I), 13 F. Supp. 2d 51, 64 (D.D.C. 1998) (citing WEBSTER's NinTH NeW COLLEGIATE DiCTIONARY (1988)).

230 Madey v. Duke Univ., 307 F.3d 1351, 1362 (Fed. Cir. 2002).
} 
funded genetic research is able to measure up to (or, perhaps, down to). Research, including federally funded basic scientific research at academic institutions, has commercial aspects. ${ }^{231}$ Even when research does nothing more than increase the institution's status or create learning opportunities for its students and faculty, the research "unmistakably further[s] the institution's legitimate business objectives. ${ }^{232}$ After passage of the Bayh-Dole amendments, ${ }^{233}$ many institutions reap direct commercial benefits by patenting discoveries from their federally funded research.

Return of results is primarily informational rather than expressive speech. An investigator returning results to a research participant generally does so not as an act of personal self-expression but in order to inform the listener. It is true that the act of returning results includes some expressive elements that convey an investigator's point of view on matters of public concern. For example, returning uncertain test results might express the investigators' view that research participants are more intelligent and better able to grasp uncertainty than some IRBs and regulators give them credit for. Returning results might express the investigator's support for a shift to a participatory model of health care that disrupts the power of traditional intermediaries and gatekeepers. It might even express a belief that laws restricting the return of results are bad policy deserving of civil disobedience. Thus, it cannot be denied that the return of results may include elements of pure (noncommercial) speech.

That said, the return of results is primarily informational rather than expressive speech: its goal is to convey information to the listener. This fact is consistent with the view that it is commercial speech. When commercial and pure (noncommercial) speech are inextricably intertwined, as they arguably may be in the context of returning results, a strong case can be made for treating the entire communication as fully protected speech deserving the highest degree of First Amendment protection. ${ }^{234}$ I do not, however, press that case here because, treating return of results as commercial speech provides a more rigorous test of this Article's hypothesis. ${ }^{235}$

\footnotetext{
231 See id. at 1362-63 (noting that research done by a university may increase the status of the institution and lure lucrative research grants, students, and faculty). 
The commercial speech doctrine pays heed to the interests of listeners. American free speech doctrine tends to be speaker-oriented because the First Amendment protects rights of speakers rather than rights of listeners. ${ }^{236}$ The speaker's right of self-expression is a major concern in many pure (noncommercial) speech contexts: the First Amendment protects the right of speakers to associate themselves with particular political, religious, moral, or cultural viewpoints. In contrast, the commercial speech doctrine often values speech for its informational function, as opposed to its expressive function. ${ }^{237}$ Valuing speech for its informational content implicitly treats audience interests as an important concern. ${ }^{238}$ "Commercial expression not only serves the economic interest of the speaker, but also assists consumers and furthers the societal interest in the fullest possible dissemination of information." 239 First Amendment protection of commercial speech rejects the "highly paternalistic" view that it benefits listeners to regulate or suppress speech and instead assumes that "people will perceive their own best interests if only they are well enough informed, and ... the best means to that end is to open the channels of communication rather than to close them."240

Various modes of communication can qualify as "speech" for First Amendment purposes. Sorrell v. IMS Health challenged a Vermont law that restricted data-mining companies' ability to disseminate prescriber-identifying pharmacy records for use in drug marketing and also restricted drug companies' use of such records in drug detailing (marketing visits). ${ }^{241}$ The State of Vermont argued that it could regulate the sale of data because such sales are "conduct" rather than "speech." "24 The Supreme Court disagreed, noting that earlier cases have "held that the creation and dissemination of information are speech within the meaning of the First Amendment." ${ }^{243}$ In the same way, testing people's genomes and telling them the results constitutes speech as well as conduct. "Facts, after all, are the beginning point

\footnotetext{
236 See Weinstein, supra note 195, at 498 (noting that American free speech doctrine focuses heavily on the rights of the speaker).

237 See, e.g., Cent. Hudson Gas \& Elec. Corp. v. Pub. Serv. Comm'n, 447 U.S. 557, 563 (1980) ("The First Amendment's concern for commercial speech is based on the informational function of advertising.").

238 Id.; see also Post, supra note 200, at 1 ("[C] ommercial speech is protected because of its informational function.").

239 Cent. Hudson, 447 U.S. at 561-62.

240 Va. State Bd. of Pharmacy v. Va. Citizens Consumer Council, 425 U.S. 748, 770 (1976).

241 Sorrell v. IMS Health Inc., 131 S. Ct. 2653, 2659 (2011).

$242 I d$. at 2666.

$243 I d$. at 2667.
} 
for much of the speech that is most essential to advance human knowledge and to conduct human affairs. There is thus a strong argument that prescriber-identifying information is speech for First Amendment purposes." ${ }^{24}$ By this same reasoning, genetic test results are speech. The Supreme Court has commented that "[t]he First Amendment protects even dry information, devoid of advocacy, political relevance, or artistic expression. A restriction on disclosure is a regulation of speech." ${ }^{245}$ In Sorrell v. IMS Health, the Supreme Court noted that a listener's "concern for the free flow of commercial speech often may be far keener than his concern for urgent political dialogue" ${ }^{246}$ and remarked, "That reality has great relevance in the fields of medicine and public health, where information can save lives." ${ }^{47}$

Return of results is speech involving health claims. Return of results often includes health claims: claims that a particular gene variant does or does not have a particular impact on human health. Courts consistently apply commercial speech doctrine in cases involving health claims. ${ }^{24}$ This body of case law is highly relevant to the return of results because health-claims cases frequently have forced courts to analyze the problem of listener vulnerability in contexts where speech conveys information that is scientifically complex or uncertain. The relevant line of cases involved First Amendment challenges to regulations that restrict the claims that manufacturers can make about their products. Regulations restricting health and environmental claims typically take the form of evidentiary requirements: before it is legal to make a claim, the claim must be scientifically validated according to specific evidentiary standards. ${ }^{249}$ A familiar example is the FDA

$245 I d$. at 2666-67 (citing IMS Health Inc. v. Sorrell, 630 F.3d 263, 271 (2d Cir. 2010) and IMS Health Inc. v. Sorrell, 631 F. Supp. 2d 434, 445 (D. Vt. 2009)).

246 Id. at 2664 (quoting Bates v. State Bar of Ariz., 433 U.S. 350, 364 (1977)) (internal quotation marks omitted).

$247 \quad I d$. at 2664.

248 See Wash. Legal Found. v. Friedman (WLF I), 13 F. Supp. 2d 51, 61 (D.D.C. 1998) (noting that courts consistently apply commercial speech doctrine in health claims cases and providing a list of examples).

249 See id. (citing examples of cases that involved challenges to regulations imposing evidentiary requirements on health and environmental claims); see also Richard A. Samp, Courts Are Arriving at a Consensus on Food and Drug Administration Speech Regulation, 58 FOOD \& DRUG L.J. 313, 314 (2003) (“[E]very major lawsuit challenging FDA speech restrictions has proceeded under the assumption that the speech in question is commercial in character." (internal quotation marks omitted)); Nathan Cortez, Can Speech by FDA-Regulated Firms Ever Be Noncommercial?, 37 AM. J.L. \& MED. 388, 397 (2011) (indicating that a survey of case law as of 2012 continues to support Samp's observation). See generally healthclaims cases cited infra Part IV. 
drug regulatory framework, which requires manufacturers to provide the agency with specific types of clinical evidence proving that a drug is safe and effective in its indicated uses before the drug can be labeled or promoted for those uses.

As discussed earlier, there is a fair degree of consensus among bioethicists that suppressing the return of results may be appropriate if the results are uncertain or lack analytical validity, clinical validity, and clinical utility/actionability. ${ }^{250}$ This cautious view is, in essence, an attempt to subject the return of results to health-claims regulation. This view would suppress the return of results that fail to meet particular standards of scientific evidence. The relationship between a test analyte (such as a gene or other biomarker) and a particular health impact must be scientifically established before the analyte can be discussed with participants. That amounts to health-claims regulation.

Regulating health claims puts a burden on free speech by suppressing claims that fail to meet the required standard of evidence. Listener vulnerability is a possible rationale for imposing this burden. As bioethicists have noted, listeners may be unqualified to assess the validity of scientific claims or they may respond inappropriately to uncertain information. ${ }^{251}$ In such circumstances, it may make sense to appoint a regulator or other learned body to police the quality of claims that can be made. Traditionally, regulators in the United States enjoyed wide latitude to use speech restrictions as a tool to promote health and safety objectives, ${ }^{252}$ and health-claims regulations were largely uncontroversial. This began to change after the commercial speech doctrine emerged in the late 1970s. ${ }^{253}$

There is a modern trend to subject health and safety regulations to greater First Amendment scrutiny, ${ }^{254}$ generally under the commercial speech doctrine. ${ }^{255}$ In recent years, the FDA repeatedly has faced First Amendment challenges in various contexts where the agency was attempting to protect the public from health claims that, in the

See discussion supra Part II.C.

See discussion supra Part II and Table 1.

See Orentlicher, supra note 191, at 300 ("When private or public actors invoked health concerns to justify their conduct, the Court often expressed less skepticism than when other reasons were invoked for public or private conduct.").

$253 I d$. at 302 (noting erosion of the special status of health care as a justification for regulation).

$254 \quad I d$. at 299

255 See Samp, supra note 249, at 314; see also Cortez, supra note 249, at 397. 
agency's view, were scientifically uncertain. ${ }^{256}$ For example, a 2002 case, Thompson v. Western States Medical Center, ${ }^{257}$ challenged the agency's efforts to restrict advertising by compounding pharmacies. ${ }^{258}$ These pharmacies offer custom-made drugs for patients who need special preparations (for example, if the patient is allergic to an inactive ingredient in the standard preparation). The FDA does not subject compounded drugs to the same clinical trial and premarket review requirements that apply to ordinary new drugs. Consequently, advertising of compounded drugs has the potential to promote drugs with poorly validated safety and effectiveness. In order to protect the public, the agency sought to restrict such advertising. The Supreme Court held that these restrictions violated the First Amendment. Other cases have challenged the agency's efforts to restrict off-label promotion of drugs and medical devices. ${ }^{259}$ Off-label promotion involves health claims that have not been validated according to the agency's usual evidentiary standards. The First Amendment constrains the FDA's ability to restrict speech about off-label uses. ${ }^{260}$ Still other cases have challenged the agency's regulation of health claims for foods and dietary supplements. ${ }^{261}$

256 See Cortez, supra note 249, at 395-97 (listing twenty-four cases in which firms subject to various forms of FDA regulation-including drug, device, compounding pharmacy, dietary supplement, and food regulation-have claimed First Amendment protection).

257535 U.S. 357 (2002).

258 Id. at $367-68$ (treating advertising by a compounding pharmacy as commercial speech that was entitled to First Amendment protection, notwithstanding the fact that the restrictions were intended to promote health).

259 See, e.g., United States. v. Caronia, 703 F.3d 149, 158-162 (2d Cir. 2012) (vacating the conviction of a pharmaceutical sales representative for promoting off-label use of a drug, holding that the government had prosecuted the defendant for his speech, and that such prosecution violated the First Amendment); Wash. Legal Found. v. Friedman (WLF I), 13 F. Supp. 2d. 51 (D.D.C. 1998) (holding that the FDA violated the First Amendment by placing certain restrictions on drug manufacturers' ability to disseminate reprints that discuss off-label uses and by restricting their involvement in continuing medical education seminars and symposia); see also United States v. Caputo, 517 F.3d. 935, 939 (7th Cir. 2008) (criticizing the FDA's ban on off-label promotion on First Amendment grounds but deciding the case on other grounds); Klasmeier \& Redish, supra note 194, at 338-50 (arguing that the FDA's current ban on drug manufacturers' promotion of off-label uses of drugs is unconstitutional on First Amendment grounds).

260 See supra note 259.

261 See, e.g., Pearson v. Shalala (Pearson I), 164 F.3d 650, 658 (D.C. Cir. 1999) (requiring the FDA, under the commercial speech doctrine, to consider whether including appropriate disclaimers-as opposed to banning speech altogether-would negate potentially misleading nature of manufacturer's claims that dietary supplements and food fiber can reduce the risks of certain cancers and neural tube defects); Whitaker v. Thompson, $248 \mathrm{~F}$. Supp. 2d 1, 2, 7 (D.D.C. 2002) (granting preliminary injunction removing the FDA's ban on health claims in dietary supplement labeling after finding that the claims were not inherently misleading and were only potentially deceptive); Alliance for Natural Health US 
Health-claims cases exemplify the point that the Central Hudson test can produce varying outcomes, depending on how well the particular speech restrictions are designed and how well the agency justifies its need to regulate the claims. In food and dietary supplement health-claims cases, courts have found some challenged speech restrictions to be unconstitutional while finding others to be permissible regulation of commercial speech. Thus, some health claims are regulable speech, while other health claims are eligible to and actually do receive constitutional protection. Health claims that appear in the labeling of FDA-approved drugs are regulable speech because-at least to date ${ }^{262}$ - the FDA premarket approval process for validating these claims continues to be regarded as a permissible regulation of free speech. In contrast, advertising of compounded drugs and various forms of speech promoting off-label uses of drugs have been held to be commercial speech that is protected by the First Amendment. Health-claims cases go both ways.

Even when a government agency has an extensive mandate to regulate the safety of drugs, devices, or other products and services, this does not necessarily imply that the agency can suppress speech as a way to promote that objective:

$[\mathrm{T}]$ he argument that a certain subset of speech may be considered completely outside of the First Amendment framework because the speech occurs in an area of extensive government regulation is a proposition whose continuing validity is at best questionable in light of the Supreme Court's most recent commercial speech cases. ${ }^{263}$

[T] he Constitution presumes that attempts to regulate speech are more dangerous than attempts to regulate conduct. That presumption accords with the essential role that the free flow of information plays in a democratic society. As a result, the First Amendment directs that the government may not suppress speech as easily as it may suppress conduct. ${ }^{264}$

These principles have obvious importance in the context of return of results. Even though the CLIA authorizes the CMS to ensure the

v. Sebelius, 714 F. Supp. 2d 48 (D.D.C. 2010) (requiring, on First Amendment grounds, that the FDA consider whether inclusion of disclaimers would negate potentially misleading effect of manufacturer's claims concerning selenium and cancer and also holding that the FDA's replacement of a claim related to prostate cancer risk was inconsistent with the First Amendment).

262 See, e.g., Aaron S. Kesselheim, Off-label Drug Use and Promotion: Balancing Public Health Goals and Commercial Speech, 37 AM. J.L. \& MED. 225, 246 (2011) ("Recent Supreme Court precedent in this area suggests that the FDA's blanket prohibition on off-label promotion could be ripe for challenge.").

263 WLF I, 13 F. Supp. 2d at 60; see also Cent. Hudson Gas \& Elec. Corp. v. Pub. Serv. Comm'n, 447 U.S. 557, 567 n.10 (1980) ("Several commercial speech decisions have involved enterprises subject to extensive state regulation.”). 
quality of laboratory testing, and even though OHRP has authority to ensure ethical treatment of human research subjects, these mandates do not necessarily empower the agencies to suppress speech to promote those objectives. "[S]peech restrictions cannot be treated as simply another means that the government may use to achieve its ends." ${ }^{265}$ Using experimental tests to study biospecimens is a form of conduct and the government, if it has a good reason to do so, can regulate or even ban such conduct. The fact that the government could ban experimental testing does not, however, imply that the government can ban speech about experimental test results. ${ }^{266}$ To determine whether specific legal restrictions on the return of results violate the Constitution, it is necessary to analyze them using the fourfactor Central Hudson framework.

\section{B. Is the Return of Results Eligible for Constitutional Protection?}

The first step of Central Hudson analysis examines characteristics of the speech itself. "For commercial speech to come within [the First Amendment], it at least must concern lawful activity and not be misleading. ${ }^{267}$ The analysis below concludes that the return of results satisfies both these criteria, based on how courts have applied them in relevant commercial speech cases.

Return of results is speech related to a lawful activity. Return of results is not the type of speech that Central Hudson refers to as "speech related to illegal activity." ${ }^{268}$ Even if a state law, the CLIA regulations, or an IRB acting pursuant to the Common Rule has "banned" the return of results, an investigator who defies the ban and returns results is not engaging in speech related to unlawful activity. Courts addressed a virtually identical question in cases challenging FDA restrictions on off-label promotion of drugs and medical devices. ${ }^{269}$ In one of those cases, ${ }^{270}$ the FDA argued that the speech concerned unlawful activity because the Food, Drug, and Cosmetic Act prohibits

\footnotetext{
$265 I d$.

266 Id. (rejecting the reasoning of an earlier case, Posadas de Puerto Rico Ass'n v. Tourism Co. of Puerto Rico, 478 U.S. 328 (1986), which had held that the government's power to regulate casino gambling implied a power to regulate speech about casino gambling). 
manufacturers' speech about off-label uses of medical products. "The court properly rejected this argument stating that the "proper inquiry is not whether the speech violates a law or regulation, but rather whether the conduct the speech promotes violates the law.'”271

An advertisement seeking to sell illegal narcotics or soliciting prostitutes would qualify as speech concerning unlawful activity. ${ }^{272}$ In contrast, talking about a lawful use of a legal medical product or about a lawfully conducted genetic test simply does not qualify. "Promotion of off-label uses does not promote unlawful activity because off-label use of drugs and medical devices by physicians is not unlawful." ${ }^{273}$ In the same way, telling a participant his or her genetic test results is not speech related to an unlawful activity. Rather, it is speech about genetic testing. If it was lawful to conduct the test, then returning results from the test is speech related to lawful activity for purposes of Central Hudson analysis.

Contrasting concepts of vulnerability in bioethics and law. Whether offlabel promotion is misleading is a "closer question" ${ }^{274}$ and the same is true of return of results. As summarized in Table 1, bioethicists express various concerns about the return of results and many of these are rooted in the belief that scientifically uncertain or poorly validated genetic test results will mislead research participants. For example, the participants may misunderstand their results; ${ }^{275}$ these misunderstandings may lead to anxiety or bad healthcare decisions; ${ }^{276}$ and participants may propagate their misunderstandings to other people, adding to public confusion about the human genome. ${ }^{277}$ These concerns cast research participants as vulnerable, incompetent listeners who may misunderstand and respond in inappropriate ways to what they are told.

The field of law also recognizes concerns about listener vulnerability. Professor Post has observed that First Amendment protection of speech seems to depend somewhat on characteristics of the listener: First Amendment doctrine seems to protect a sphere of communication between people who "are presumed to be independent and self-possessed," but is less likely to protect "communications between

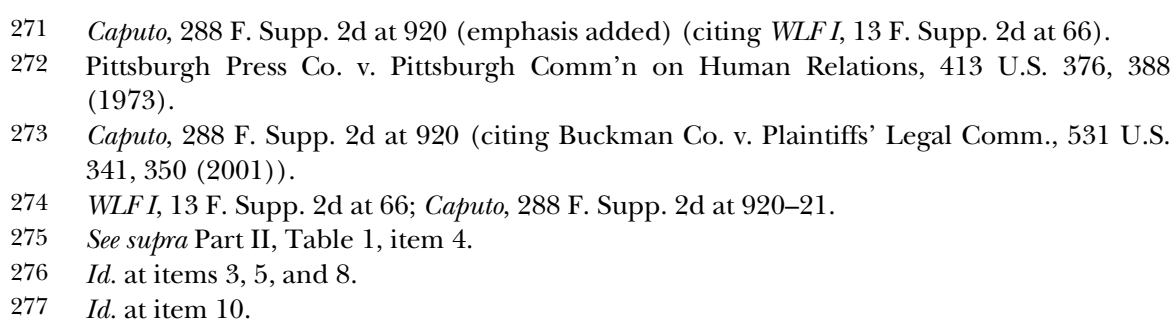


persons deemed to be involved in relationships of dependence or reliance.”278 By this view, First Amendment doctrine protects speech in situations where the listeners are conceived as autonomous, selfdetermining individuals, but when listeners are conceived as vulnerable and not able to discern their own best interests, there is a greater willingness to let the government regulate what the listeners can be told.

The problem with this concern is that virtually all speech is misleading if one presumes a sufficiently unsophisticated listener. Suppressing speech can inflict real injuries on speakers and listeners alike. ${ }^{279}$ "To allow [communication] to be fettered is to fetter ourselves. ${ }^{280}$ It compounds an insult with an injury to declare people naive and then cite their alleged naiveté as a reason to wall them off from communication. As a federal appeals court noted in a First Amendment case involving regulation of scientifically uncertain health claims, "If the protections afforded commercial speech are to retain their force, we cannot allow rote invocation of the words 'potentially misleading' to supplant the [government's] burden to demonstrate that the harms it recites are real and that its restriction will in fact alleviate them to a material degree." ${ }^{281}$ The Supreme Court maintains that " $[\mathrm{t}]$ his burden is not satisfied by mere speculation or conjecture." 282

While law and bioethics both recognize the problem of listener vulnerability, law is somewhat more cautious about asserting that people are vulnerable as a reason to forbid others to speak to them. When bioethicists assert that people are vulnerable or incompetent, this often is done with the best motives and in a spirit of erring on the side of protecting people. Lawyers perhaps take a more jaundiced view of such assertions, having often seen them made with nefarious motives (for example, adult child seeks to have mom declared incompetent with the aim of taking control of her assets).

The legal concept of misleading speech. Rote assertions that return of results is misleading ${ }^{283}$ may be enough to convince bioethicists that it

\footnotetext{
278 Post, supra note 200, at 23.

279 See Elrod v. Burns, 427 U.S. 347, 373 (1976) ("The loss of First Amendment freedoms, for even minimal periods of time, unquestionably constitutes irreparable injury." (citing N.Y. Times Co. v. United States, 403 U.S. 713 (1971))).

280 Grosjean v. Am. Press Co., 297 U.S. 233, 250 (1936) (speaking of a free press).

281 Pearson v. Shalala (Pearson I), 164 F.3d 650, 659 (D.C. Cir. 1999) (quoting Ibanez v. Fla. Dep't of Bus. \& Prof'l Regulation, 512 U.S. 136, 146 (1994)) (internal quotation marks omitted).

282 Edenfield v. Fane, 507 U.S. 761, 770-71 (1993).

283 Id.
} 
is appropriate to suppress speech, but they would not convince a court. "Because there is a constitutional presumption in favor of speech, a defendant has the burden of proof to rebut that presumption with evidence that the speech is inherently misleading." ${ }^{284}$ In First Amendment cases where a speaker is challenging a speech restriction, the defendant is the proponent of the speech restriction (usually a state or the federal government). Thus, the party who wants to restrict speech has the burden to prove it is misleading. ${ }^{285}$ " $[\mathrm{M}]$ ost courts have become increasingly demanding in insisting that regulatory restrictions be buttressed by hard evidence supporting the necessity of such restrictions." 286

Courts recognize a distinction between speech that is inherently misleading and speech that is only potentially misleading. ${ }^{287}$ Inherently misleading commercial speech is not entitled to constitutional protection and the government may regulate it or ban it altogether. ${ }^{288}$ If speech is only potentially misleading, it is eligible for constitutional protection and the government can regulate it only if the other three Central Hudson factors are met (that is, if there is a substantial government interest that is directly advanced by the regulation, which must be no more extensive than necessary). ${ }^{289}$

Central Hudson considered speech inherently misleading if it was "more likely to deceive the public than to inform it." 290 An earlier case had formulated this concept by saying that the speech "more often than not will be injurious." ${ }^{291}$ Some cases, ${ }^{292}$ although it arguably is simplistic to do so, seem to relate the distinction between potential-

284 Bioganic Safety Brands, Inc. v. Ament, 174 F. Supp. 2d 1168, 1180 (D. Colo. 2001) (citing Revo v. Disciplinary Bd. of the Supreme Court, 106 F.3d 929, 932-33 (10th Cir. 1997)).

285 See Edenfield, 507 U.S. at 770-71 ("[A] governmental body seeking to sustain a restriction on commercial speech must demonstrate that the harms it recites are real and that its restriction will in fact alleviate them to a material degree.").

2861 RODNEY A. SMOLLA, LAW OF LAWYER ADVERTISING § 6:2 (updated Oct. 2013).

287 Borgner v. Brooks, 284 F.3d 1204, 1210 (11th Cir. 2002) (demonstrating that the Supreme Court had recognized a distinction between inherently and potentially misleading speech even before Central Hudson) (citing In re R.M.J., 455 U.S. 191, 203 (1982)).

288 See Cent. Hudson Gas \& Elec. Corp. v. Pub. Serv. Comm'n, 447 U.S. 557, 563 (1980) (" $[\mathrm{T}]$ here can be no constitutional objection to the suppression of commercial messages that do not accurately inform the public about lawful activity. The government may ban forms of communication more likely to deceive the public than to inform it." (citing Friedman v. Rogers, 440 U.S. 1, 13 (1979); Ohralik v. Ohio State Bar Ass'n., 436 U.S. 447, 464 (1978)).

289 See In re R.M.J., 455 U.S. 191, 203 (1982); see also Wash. Legal Found. v. Friedman (WLF I), 13 F. Supp. 2d 51, 66 (D.D.C. 1998); Borgner, 284 F.3d at 1210.

290 Cent. Hudson, 447 U.S. at 563 (citing Friedman, 440 U.S. at 13; Ohralik, 436 U.S. at 464).

291 Ohralik, 436 U.S. at 466.

292 See, e.g., Int'l Dairy Foods Ass'n v. Boggs, 622 F.3d 628, 636 (6th Cir. 2010) (distinguishing various types of health claims). 
ly and inherently misleading claims to the distinction between true claims and false or deceptive claims. Thus, "[t]ruthful advertising" is constitutionally protected, ${ }^{293}$ but the government is "free to prevent the dissemination of commercial speech that is false, deceptive, or misleading." ${ }^{294}$ Showing that a claim is true strongly militates against the conclusion that it is inherently misleading, even if listeners are apt to form a false impression from it. However, the concept of "deceptive" leaves the door slightly ajar for a factually true statement nevertheless to be inherently misleading. Some courts take the view that "speech is only 'inherently misleading' if it would be misleading in all circumstances" ${ }^{295}$ and treat speech as merely "potentially misleading" if it is misleading in some circumstances but not in others. ${ }^{296}$ Some courts consider that for "a particular mode of communication to be inherently misleading, it must be incapable of being presented in a way that is not deceptive." ${ }^{297}$ Simply declaring that speech is inherently misleading is not sufficient to justify restrictions on speech:

Whether speech is "inherently misleading" . . is a determination for the court, not the legislature [or regulators], to make. If a legislature could place speech outside of First Amendment protection by simply declaring the speech "inherently misleading," the First Amendment to the United States would be subject to de facto modification by state legislatures. Clearly, this would violate the Supremacy Clause. ${ }^{298}$

"Whether speech is inherently misleading depends upon ... the possibilities for deception, whether experience has proved that in fact that such advertising is subject to abuse, and the ability of the intended audience to evaluate the claims made." ${ }^{299}$ The listener's sophistication is one factor courts consider but it is not necessarily dispositive. In United States v. Caputo, which involved off-label promotion of a medical device, the court noted the fact that the promotion was di-

R.M.J., 455 U.S. at 203.

Zauderer v. Office of Disciplinary Counsel of the Supreme Court, 471 U.S. 626, 638 (1985) (citing Friedman, 440 U.S. at 1).

Bioganic Safety Brands, Inc. v. Ament, 174 F. Supp. 2d 1168, 1181 (D. Colo. 2001).

Ass'n of Nat'l Advertisers v. Lungren, 44 F.3d 726, 730-31 (9th Cir. 1994), cert. denied, 516 U.S. 812 (1995) (determining that environmental claims using the terms "ozone friendly," "biodegradable," "photodegradable," "recyclable," and "recycled" were only potentially misleading).

7 See, e.g., Revo v. Disciplinary Bd. of the Supreme Court, 106 F.3d 929, 933 (10th Cir. 1997) (citing R.M.J., 455 U.S. at 203).

Bioganic, 174 F. Supp. 2d at 1180; see also Peel v. Attorney Registration \& Disciplinary Comm 'n, 496 U.S. 91, 108 (1990) (stating that whether speech is inherently misleading is a "question of law").

99 Wash. Legal Found. v. Friedman (WLF I), 13 F. Supp. 2d 51, 66-67 (D.D.C. 1998) (citations omitted) (internal quotation marks omitted); see also United States v. Caputo, $288 \mathrm{~F}$. Supp. 2d 912, 920-21 (N.D. Ill. 2003) (citing WLF I, 13 F. Supp. 2d at 51). 
rected at physicians, a sophisticated audience, before concluding that the speech was not inherently misleading. ${ }^{300}$ But courts sometimes focus on other factors. In Washington Legal Foundation v. Friedman, ${ }^{301}$ an off-label drug promotion case, the court focused primarily on the nature and intrinsic reliability of the speech (which involved distributing peer-reviewed articles that discussed off-label uses) ${ }^{302}$ in concluding that it was not inherently misleading. ${ }^{303}$

When cases involve uncertain or poorly substantiated health and environmental claims, a key question is whether adding a disclosure or disclaimer would "suffice to mitigate the claim's misleadingness." Whether to ban speech or simply require disclosures is mainly a question for Step Four of Central Hudson analysis, when courts consider whether the government's speech restrictions are more extensive than they need to be. However, disclosures also may be relevant during Step One as courts decide whether speech is inherently misleading. If adding a disclosure would make speech non-misleading, this tends to suggest that the speech is only potentially misleading, and the proper response may be to regulate it by requiring the needed warning or disclosure. ${ }^{305}$ If the problem simply cannot be cured by adding disclaimers, then the speech may well be inherently misleading such that an outright ban is justified. ${ }^{306}$ Thus, the effectiveness of disclaimers is mainly a question for Step Four, but it also may be relevant during Step One of Central Hudson analysis.

Are poorly substantiated health claims inherently misleading? An influential case on these issues is Pearson v. Shalala" ("Pearson I") involving a First Amendment challenge to restrictions the FDA imposed on

\footnotetext{
300 Caputo, 288 F. Supp. 2d at 921.

301 WLF I, 13 F. Supp. 2d at 51.

$302 \quad I d$. at 67.

303 Id. at $68-69$.

304 Pearson v. Shalala (Pearson I), 164 F.3d 650, 659 (D.C. Cir. 1999) (not ruling out the possibility that it would be permissible for the FDA to ban a claim outright if the claim's misleading nature was "incurable by a disclaimer" (citing FTC v. Brown \& Williamson Tobacco Corp., 778 F.2d 35, 42-43 (D.C. Cir. 1985))).

305 See, e.g., In re R.M.J., 455 U.S. 191, 203 (1982) (“[T]he States may not place an absolute prohibition on certain types of potentially misleading information ... if the information also may be presented in a way that is not deceptive."); see also Pearson I, 164 F.3d at 659 ("The government's general concern that ... consumers might assume that a claim on a supplement's label is approved by the government, suggests an obvious answer: The agency could require the label to state that 'The FDA does not approve this claim."').

306 See Pearson v. Shalala (Pearson II), 130 F. Supp. 2d 105, 118 (D.D.C. 2001) ("[Pearson I] clearly ruled that the FDA may not prohibit a health claim unless it first makes a 'showing' that the claim's alleged 'misleadingness' could not be cured through the use of a disclaimer or other types of disclosure."). 
health claims for dietary supplements. In Pearson I, the D.C. Circuit Court of Appeals considered whether "health claims lacking 'significant scientific agreement' are inherently misleading and thus entirely outside the protection of the First Amendment."308 The agency had asserted its "common sense judgment" that it advances consumers' health for the FDA to ban health claims that have not been approved by the agency under a "significant scientific agreement" standard. ${ }^{309}$ The court of appeals stated that it regarded "as dubious any justification that is based on the benefits of public ignorance" ${ }^{\# 10}$ and rejected the FDA's assertion in scathing terms:

As best we understand the government, its [argument] runs along the following lines: that health claims lacking "significant scientific agreement" are inherently misleading because they have such an awesome impact on consumers as to make it virtually impossible for them to exercise any judgment at the point of sale. It would be as if the consumers were asked to buy something while hypnotized, and therefore they are bound to be misled. We think this contention is almost frivolous. We reject it. ${ }^{311}$

In Pearson I, the court of appeals referred favorably to an earlier case that rejected the "paternalistic assumption" that recipients of an allegedly misleading communication are "no more discriminating than the audience for children's television." ${ }^{312}$ Whether speech is inherently misleading should not be judged by reference to the most credulous listener who ever might be exposed to it. Other courts have indicated that "the mere fact that someone is misled by a particular communication is not proof that the communication is inherently misleading."

Some courts want to see evidence that listeners' confusion was caused by the speech that the government is seeking to ban, rather than by some other source of information. In a case where the State of Ohio alleged that a milk label was giving consumers the false impression that it is safer to drink milk from cows not treated with artificial hor-

$308 \quad I d$. at 655

309 Id. at 656. Pearson I also involved a challenge to the constitutionality of the FDA's illdefined "significant scientific agreement" standard, $i d$. at 655 , but the court of appeals found that the FDA's failure to define the standard violated the Administrative Procedure Act, so it did not need to decide those constitutional issues, $i d$. at 660 .

$310 I d$. at 656 (quoting Bates v. State Bar of Ariz., 433 U.S. 350, 375 (1977)).

311 Pearson I, 164 F.3d at 655 (citation omitted); see also Wash. Legal Found. v. Friedman (WLF I), 13 F. Supp. 2d 51, 67 (D.D.C. 1998) ("In asserting that any and all scientific claims ... are presumptively untruthful or misleading until the FDA has had the opportunity to evaluate them, FDA exaggerates its overall place in the universe.”).

312 Id. (citing Peel v. Attorney Disciplinary Comm'n, 496 U.S. 91, 111 (1990) (Marshall, J., concurring)).

313 Bioganic Safety Brands, Inc. v. Ament, 174 F. Supp. 2d 1168, 1181 (D. Colo. 2001). 
mones, the state pointed to some allegedly confused customers to support its allegation that the label was inherently misleading. ${ }^{314}$ However, the court noted that one of these customers claimed that she formed the impression that the milk was safer based on conversations with her oncologist, rather than by reading milk labels. ${ }^{315}$ The fact that oncologists make inaccurate statements was no reason to ban the labeling of milk.

Moreover, courts tend not to judge whether a claim is inherently misleading under the worst-case assumptions that bioethicists sometimes employ when assessing risks. ${ }^{316}$ Courts' non-alarmist approach is exemplified by the case Bioganic Safety Brands, Inc. v. Ament, which held that it was not inherently misleading for a pesticide to claim that it was "safe for kids." "317 The State of Colorado had asserted that "there is no realistic way to counter the misleading impression that such pesticide is safe for all kids of all ages with whatever mental or physical health problems they may have.”318 The court, however, found it implausible to believe that consumers reading the claim would think it meant the product "safe for all kids of all ages and all possible health problems or disabilities without any responsible adult supervision." 319 The court rejected the state's worst-case (and hidden) assumption that children purchase and use pesticides with no involvement of their parents.

In Pearson I, the "Court of Appeals strongly suggested, without declaring so explicitly, that [the unconfirmed health claim in question] was only 'potentially misleading,' not 'inherently misleading,",320 and "that when 'credible evidence' supports a claim . . . that claim may not be absolutely prohibited." 321 Pearson I suggests that when a claim has considerable evidence to support it but the evidence is mixed or unclear, the proper approach is to disclose the uncertainty rather than ban the speech altogether. ${ }^{322}$ However, Pearson I does not rule out the possibility that a ban may be warranted if the evidence is so

Int'l Dairy Foods Ass'n v. Boggs, 622 F.3d 628, 638 (6th Cir. 2010).

Id. at 638-39.

See generally George J. ANNAS, WORST CASE Bioethics, at xi (2010) (reflecting on the use of worst case scenarios and commenting that worst case scenarios are almost always counterproductive as planning exercises).

Bioganic, 174 F. Supp. 2d at 1177.

$I d$. at 1182 (internal quotation marks omitted).

Id. (emphasis added).

Pearson v. Shalala (Pearson II), 130 F. Supp. 2d 105, 110 (D.D.C. 2001).

Id. at 114 (citing Pearson v. Shalala (Pearson I), 164 F.3d 650, 659 (D.C. Cir. 1999)).

Pearson I, 164 F.3d at 659. 
heavily skewed against a claim that a disclaimer would not suffice. ${ }^{323}$ Pearson I envisioned that this might occur "where evidence in support of a claim is outweighed by evidence against the claim." ${ }^{324}$

For example, if the weight of the evidence were against the hypothetical claim that "Consumption of Vitamin E reduces the risk of Alzheimer's disease," the agency might reasonably determine that adding a disclaimer such as "The FDA has determined that no evidence supports this claim" would not suffice to mitigate the claim's misleadingness.

Note, however, that Pearson I did not envision banning speech in situations where evidence supporting a claim is weak but uncontradicted. Pearson I left open the possibility of banning speech only when the evidence cuts both ways and the weight of the evidence disfavors the claim. ${ }^{326}$

A later case, Pearson II, challenged whether the FDA had appropriately applied this concept. ${ }^{327}$ The agency had banned a claim about the health effects of folic acid after stating that the claim was against the weight of scientific evidence. ${ }^{328}$ Courts have "the authority to examine and rule on any actions of a federal agency that allegedly violate the Constitution," and courts give little deference to a regulator's opinion about constitutional questions. ${ }^{329}$ In contrast, courts generally do give considerable "deference to an agency's assessment of scientific or technical data within its area of expertise." $" 330$ The court in Pearson II was "mindful that it is generally not for the judicial branch to undertake comparative evaluations of conflicting scientific evidence," cluded that "even a cursory examination of the scientific literature on which the FDA relied in its Folic Acid Decision demonstrates that the FDA's conclusion that the 'weight' of the evidence was against plaintiff's Folic Acid claim was arbitrary, capricious and otherwise in viola-

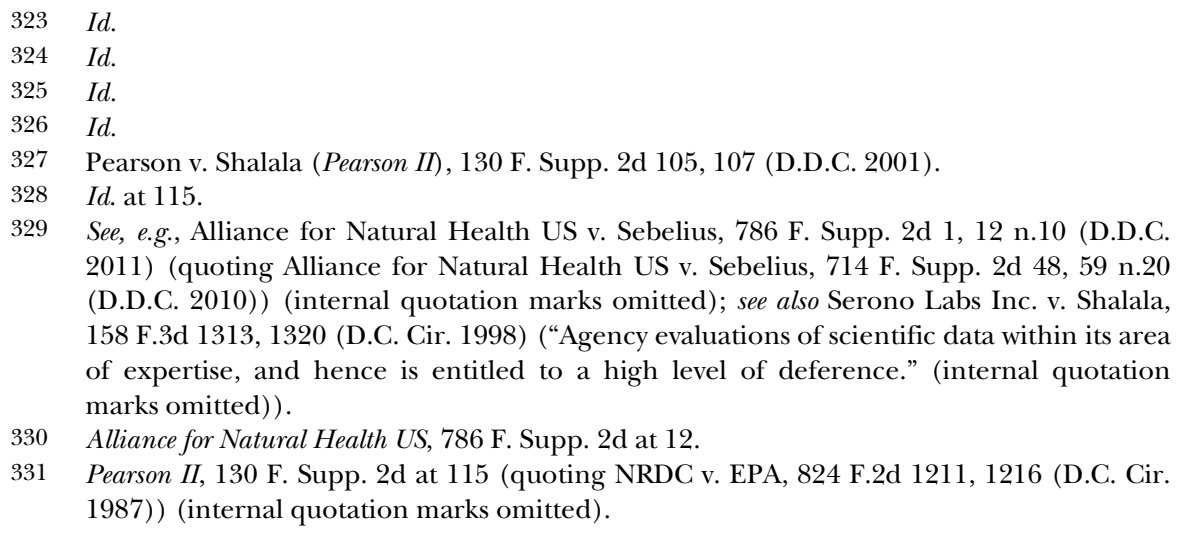


tion of law." ${ }^{332}$ Those who wish to ban a scientific claim cannot simply make conclusory statements that the weight of the evidence is against the claim. The weight of the evidence really must be against it, and in First Amendment cases, courts are prepared to depart from their usual deferential posture in order to verify that this is so.

Are claims inherently misleading if current science can neither prove them nor disprove them? The 2010 milk-labeling case, International Dairy Foods Ass'n v. Boggs, ${ }^{333}$ pondered a question that is highly relevant to the return of results: Are claims inherently misleading when the technology to confirm that they are true simply does not yet exist? In that case, an Ohio regulation refused to let farmers label their milk "rbST free" in situations where the farmers had avoided treating their cows with the artificial hormone rbST to stimulate milk production. ${ }^{334}$ The state alleged-and a lower court had agreed-that such claims were inherently misleading because, using current testing technology, there is no detectable difference between milk produced by rbSTfree and rbST-treated cows. ${ }^{335}$ Thus, the label created a misleading impression that "rbST-free" milk was better than other milk, when no real difference could be measured.

On appeal, however, the Sixth Circuit Court of Appeals noted that "the failure to discover rbST in [milk from treated cows] is not necessarily because the artificial hormone is absent in such milk, but rather because scientists have been unable to perfect a test to detect it." ${ }^{336}$ Using present testing technology, the notion that milk from rbST-free cows is safer than other milk was not provably true, but neither was it provably false. If it was not provably false, then it was not "inherently misleading" to leave consumers with the impression that it may be true. $^{337}$ Any misimpression could be addressed by requiring disclosure that it simply is not presently known whether the milk is different. ${ }^{338}$ Labeling milk "rbST-free" thus was not inherently misleading. At oral argument, the state conceded that milk from treated cows "could" contain rbST although no test has been able to verify this. ${ }^{339}$ compositional difference may actually exist between the two types of milk and left open the possibility that future technologies may be able to detect the presence of rbST in milk from treated cows).

338 Id. at $639-40$.

339 Id. at 637.
} 
That concession was fatal to the state's argument: if something "could" be true, it is hard to maintain that it is inherently misleading.

As already noted, ${ }^{340}$ the party wishing to restrict speech has the burden to prove it is misleading. International Dairy Foods displays the impact this has in situations where scientific evidence is inconclusive. The court of appeals in International Dairy Foods remanded the case back to the lower court for further proceedings, indicating that if the state wanted to ban the speech as "inherently misleading," the state needed to produce evidence that the speech was false. ${ }^{341}$ "But there is no evidence in the record to verify the State's contention. In light of this insufficiently developed factual record, the State has not shown that it is entitled" to ban the "rbST-free" label as inherently misleading. ${ }^{342}$ When the available scientific evidence is inconclusive, it is difficult indeed for the government to prove a health claim false. The court of appeals commented that "it seems peculiar to deny the consumer, on the ground that the information is incomplete, at least some of the relevant information needed to reach an informed decision." ${ }^{343}$ Even if it is not yet known whether milk from "rbST-free" cows is better than milk from rbST-treated cows, consumers still may benefit from the "incomplete" information that the cow whose milk they are drinking was not treated with rbST. That fact is known, even if its significance for the quality of milk products remains uncertain.

The problem of incomplete information obviously arises when returning genetic test results. There may be trustworthy information that a person has a gene variant but considerable uncertainty about that variant's health or reproductive significance. Many bioethicists agree that it is appropriate to suppress the return of results in this situation. ${ }^{344}$ This view presumes that the investigator who wishes to return results has the burden of establishing that the findings have the requisite levels of scientific certainty and meaning, before he or she can speak. Yet, as International Dairy Foods makes clear, the burden of validation does not lie with the speaker for First Amendment purposes. Instead, the burden of invalidation rests with those who seek to declare the speech inherently misleading and suppress the return of results.

\footnotetext{
$340 \quad$ See discussion supra Part IV.B.

341 Boggs, 622 F.3d at 638.

342 Id.

$343 I d$. at 636 (quoting Bates v. State Bar of Ariz., 433 U.S. 350, 374-75 (1977)) (internal quotation marks omitted).

344 See discussion supra Parts II.A, II.C.
} 
In the face of genuine scientific uncertainty (as when a genephenotype association is not clearly established as valid but also is not provably invalid), the government has the burden to show that the claimed association is false or deceptive before it can suppress speech. If there is some evidence to support the association but the association remains subject to uncertainty, the Pearson cases and International Dairy Foods v. Boggs suggest it would not be constitutional to ban the speech outright, although it may be perfectly appropriate to require a disclosure that frankly admits how uncertain or even dubious the association actually is. If the available evidence simply cannot confirm whether the claim is true or false, then the party who bears the burden of proof will lose. The First Amendment rests that burden on those who would suppress speech rather than on the speaker.

Who has the burden of validating or invalidating health claims? The cautious bioethical view treats the speaker as bearing the burden of validation in situations where scientific evidence is inconclusive. That approach would not satisfy a court in a First Amendment challenge to a law or regulation that restricts the return of results. Because this point is so critical in the present bioethical debate, it bears repeating for emphasis: as Pearson II points out, "even if [a claim] is in some respects 'potentially misleading,' the resulting injury that could flow to consumers cannot compare, as a matter of law, with the First Amendment injury" that comes from unwarranted suppression of speech. ${ }^{345}$ The government "may not place an absolute prohibition on ... potentially misleading information ... if the information also may be presented in a way that is not deceptive." ${ }^{346}$

Pearson I "clearly ruled that the FDA may not prohibit a health claim unless it first makes a 'showing' that the claim's alleged 'misleadingness' could not be cured through the use of a disclaimer or other types of disclosure." "Subsequent cases have debated just how much actual evidence this "showing" requires. ${ }^{348}$ In Pearson I, the FDA

Pearson v. Shalala (Pearson II), 130 F. Supp. 2d 105, 119 (D.D.C. 2001).

Pearson v. Shalala (Pearson I), 164 F.3d 650, 655 (D.C. Cir. 1999) (citing In re R.M.J., 455 U.S. 191, 203 (1982)).

347 Pearson II, 130 F. Supp. 2d at 118 (discussing Pearson I, 164 F.3d at 658). 348 See Alliance for Natural Health US v. Sebelius, 714 F. Supp. 2d 48, 62 (D.D.C. 2010) (stat-
ing that the court in Whitaker v. Thompson arguably went even further than Pearson I by suggesting that the government must provide empirical evidence proving that the public would still be deceived even if the claim was qualified by a disclaimer) (referencing Whitaker v. Thompson, 248 F. Supp. 2d 1, 11 (D.D.C. 2002)). But see Alliance for Natural Health US v. Sebelius, 786 F. Supp. 2d 1, 14 (D.D.C. 2011) ("This Court agrees that Pearson I does not require the FDA to make an empirical showing of the inefficacy of a disclaimer before prohibiting a claim that is not supported by credible evidence."). 
asserted that adding disclaimers to uncertain health claims would confuse consumers, ${ }^{349}$ but "all the government offer[ed] in support [was] the FDA's pronouncement that 'consumers would be considerably confused by a multitude of claims with differing degrees of reliability." " ${ }^{50}$ This unsupported assertion was not sufficient to justify a speech ban. Anyone seeking to ban the return of uncertain or poorly substantiated results should be aware that courts expect real evidence of why a disclosure would not work. Courts continue to debate precisely how much evidence is required, ${ }^{351}$ but merely alleging that "participants will be confused" is clearly not enough.

Many scholars in the fields of bioethics and medicine call for evidence-based medicine, but do not see a corresponding need for evidence-based policies and evidence-based regulations. Many recommendations to suppress the return of research results rest on little more than conjectures and suppositions. Holm and Taylor note that return of "genomic research results has historically been opposed, by some, based on an assumption that therapeutic misconceptions are inevitable, that harm necessarily flows from a misconception and is unpreventable and incurable, and that such harm necessarily outweighs any potential benefit, regardless of how benefit might be conceived or measured. ${ }^{\text {} 52}$ In other words, bioethicists at times seem to presume that research participants are, to use Pearson I's words, "no more discriminating than the audience for children's television." ${ }^{353}$ If the recommended speech restrictions were implemented into law, those laws would face First Amendment challenges, and courts in those challenges would expect proponents of speech restrictions to present real evidence to support these conjectures, suppositions, and assumptions. As the Supreme Court stated in Central Hudson, "conditional and remote eventualities cannot justify silencing” speech. ${ }^{354}$ The First Amendment requires proponents of speech restrictions to show that the proposed restrictions are evidence-based regulations. Little in the literature on return of results suggests the bioethics community would be able to do so.

\footnotetext{
349 Pearson I, 164 F.3d at 659.

350 Id. (quoting the FDA's pronouncement at 59 Fed. Reg. at 6279).

351 See supra note 348 (listing cases that have debated this point).

352 Holm \& Taylor, supra note 121, at 670; see also Kohane \& Taylor, supra note 112, at 1-2 (" $[\mathrm{P}]$ roviding results would both depend on and foster the misconception that clinical research is about clinical care (referred to here as therapeutic misconception).").

353 Pearson I, 164 F.3d at 655 (quoting Peel v. Attorney Registration \& Disciplinary Comm'n, 496 U.S. 91, 105 (1990)) (internal quotation marks omitted).

354 Cent. Hudson Gas \& Elec. Corp. v. Pub. Serv. Comm'n, 447 U.S. 557, 569 (1980).
} 
Conclusion: Return of results is eligible for constitutional protection. The return of results is neither "speech related to unlawful activity" nor is it "inherently misleading." It is therefore eligible for First Amendment protection as commercial speech. After Step One of Central Hudson analysis, the focus shifts away from the speech that is being regulated and toward the regulation itself. Regulations restricting lawful, non-misleading speech must satisfy three constraints: ${ }^{355}$ the government's asserted interest in regulating the speech must be substantial $;{ }^{356}$ the regulation must directly advance that interest; ${ }^{357}$ and the restriction on speech must be no more extensive than necessary. ${ }^{358}$ A law or regulation must satisfy all three of these conditions and is unconstitutional if it fails any one of these criteria.

\section{Does the Government Have a Substantial Interest in Suppressing the Return of Results?}

Because Steps Two-Four of the Central Hudson test are regulationspecific, a separate analysis is necessary for each law or regulation that is facing a First Amendment challenge. For example, a state law that restricts the return of results would need to be analyzed separately from restrictions imposed under CLIA's research exception. Fortunately, case law reveals several common principles that have general relevance when determining, at Step Two of Central Hudson analysis, whether the government has a substantial interest in suppressing speech.

The government's "asserted interest in regulating speech" refers to the objective the government claims it is trying to achieve by imposing speech restrictions. To ascertain the government's interest, courts consider statements the government made when it imposed the speech restrictions as well as explanations the government offers at the time of the First Amendment challenge. Courts tend to be fairly deferential to the government's assessment that a particular interest is substantial. It is not uncommon to see a court simply assume after cursory analysis that the government's stated interest is substantial and then move on to Steps Three and Four of Central Hudson analysis. ${ }^{359}$ The government often is able to slip through Step Two by

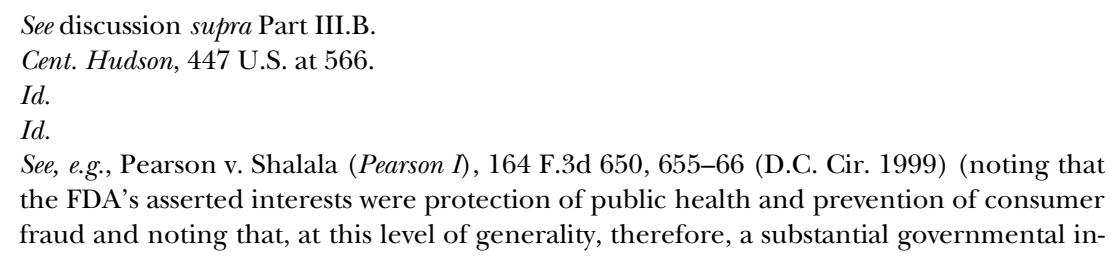


asserting a general interest in "ensuring the accuracy of commercial information in the marketplace" $"$ or in "promoting the health, safety, and welfare of its citizens." ${ }^{361}$ Occasionally, however, courts do find fault with the government's asserted interest and conclude that a speech regulation is unconstitutional at Step Two. Cases where this has happened demonstrate three points that are relevant to the return of results.

The government's interest in keeping the public from being misled. The first point is that the government's interest in protecting the public from being misled does not justify banning health claims that are uncertain but not provably false. Some courts reach this conclusion at Step Two of Central Hudson analysis; they reject the notion that the government has a substantial interest in shielding people from speech that is scientifically uncertain. ${ }^{362}$ In the International Dairy Foods and Bioganic cases discussed earlier, the only asserted governmental interests were to protect the public from being misled. ${ }^{363}$ In International Dairy Foods, the milk processors who were challenging the state's labeling regulations were willing to concede that the state had a substantial interest in preventing consumer deception. The court was less willing to concede this and insisted that "the State bears the burden to demonstrate that the harms it recites are real." " ${ }^{364}$ This was difficult for the state to do because the court had just concluded, in Step One of the Central Hudson analysis, that the milk labels in question were not inherently misleading. In light of that finding, the state's proof fell short of establishing the substantial interest required at Step Two. ${ }^{365}$

In Bioganic, ${ }^{366}$ the court chided the state for "misapprehend[ing] the analysis prescribed by Central Hudson." ${ }^{367}$ The court pointed out

terest is undeniable, and that the more significant questions under Central Hudson are the next two factors).

360 Edenfield v. Fane, 507 U.S. 761, 769 (1993).

361 Rubin v. Coors Brewing Co., 514 U.S. 476, 485 (1995).

362 Other courts address the issue at Steps Three and Four of Central Hudson analysis, rejecting a speech ban as too drastic a response when disclosure would alert listeners to the scientific uncertainty.

363 See Int'l Dairy Foods Ass'n v. Boggs, 622 F.3d 628, 638 (6th Cir. 2010) (stating that the purpose of the challenged milk-labeling state regulation was to prevent the use of false and misleading labeling); Bioganic Safety Brands, Inc. v. Ament, 174 F. Supp. 2d, 1168, 1182 (D. Colo. 2001) ("According to Defendant, Colorado has a substantial interest in protecting the public from claims that pesticides are 'safe,' which by their very nature are inherently misleading." (citation omitted)).

364 Boggs, 622 F.3d at 638 (quoting Ibanez v. Fla. Dep't of Bus. \& Prof'l Regulation, 512 U.S. 136, 146 (1994)) (internal quotation marks omitted).

$365 \quad I d$. at 639.

$366 \quad 174$ F. Supp. 2d at 1182. 
that if the claims were inherently misleading, the Central Hudson analysis would have ended at Step One. The fact that the analysis had proceeded to Step Two implied that the claims were not inherently misleading. ${ }^{368}$ Therefore, the state could not maintain it had a substantial interest in protecting the public from inherently misleading claims. In Bioganic, the state's speech ban was found unconstitutional after Step Two of the analysis because the state had failed to identify a substantial interest that the speech ban would serve. ${ }^{369}$

Based on these decisions, the government does not have a substantial interest in banning the return of results that are uncertain or that lack an established clinical or reproductive significance. As explained in Part IV.C supra, such results are not inherently misleading in a legal sense of the word. To ban the return of such results, the government needs to do more than merely assert an interest in keeping research subjects from being misled. ${ }^{370}$ Even if speech "communicates only an incomplete version of the relevant facts, the First Amendment presumes that some accurate information is better than no information at all." ${ }^{371}$ The government does not have a substantial interest in shielding people from the reality that some scientific findings are uncertain at the time they are communicated.

The Supreme Court confirmed this in Western States, ${ }^{372}$ the 2002 case that challenged the FDA's ban on advertising by compounding pharmacies. The agency, perhaps familiar with the previous year's decision in Bioganic, did not assert a substantial interest in keeping consumers from being misled. However, a dissenting justice voiced concerns about the "systematic effect... of [communications] that will not fully explain the complicated risks at issue" and worried that patients who see such advertisements "will be confused about the drug's risks." ${ }^{373}$ Because the dissent had raised this issue, the Court proceeded to analyze it. If the government had an interest in protecting vulnerable listeners, "this interest could be satisfied by the far less restrictive alternative of requiring each compounded drug to be labeled with a warning that the drug had not undergone FDA testing

\footnotetext{
367 Id

$368 I d$.

$369 \quad I d$

370 See, e.g., Cent. Hudson Gas \& Elec. Corp. v. Pub. Serv. Comm'n, 447 U.S. 557, 566 n.9 (1980) ("[I]n recent years th[e Supreme] Court has not approved a blanket ban on commercial speech unless the expression itself was flawed in some way, either because it was deceptive or related to unlawful activity.").

371 Cent. Hudson, 447 U.S. at 562 (citing Bates v. State Bar of Ariz., 433 U.S. 350, 374 (1977)).

372 Thompson v. W. States Med. Ctr., 535 U.S. 357 (2002).

373 Id. at 376.
} 
and that its risks were unknown.,"374 The Court noted that "the choice among these alternative approaches is not ours to make or the [legislature's]. It is precisely this kind of choice, between the dangers of suppressing information, and the dangers of its misuse if it is freely available, that the First Amendment makes for us."

When returning research results that are subject to uncertainty, the First Amendment makes a choice: disclose the uncertainties rather than ban the speech. "[I]n recent years, [the Supreme] Court has not approved a blanket ban on commercial speech unless the expression itself was flawed in some way, either because it was deceptive or related to unlawful activity." frankly disclosed as such can hardly be viewed as "deceptive."

Governmental interests that are inconsistently pursued. A second relevant point is that it is hard for the government to claim that an interest is "substantial" when the government has a history of pursuing the interest in an inconsistent manner. This point is illustrated in Sorrell v. IMS Health, the recent case that challenged a Vermont statute restricting data-mining companies' ability to disseminate prescriberidentifying pharmacy records for use in drug marketing. ${ }^{377}$ The State of Vermont asserted that one of its objectives was to protect the confidentiality of physicians' prescribing records. ${ }^{378}$ The Supreme Court was willing to assume that physicians do have an interest in keeping their prescribing decisions confidential. ${ }^{379}$ However, the state's asserted interest in protecting physician's privacy was belied by the fact that the statute let pharmacies "share prescriber-identifying information with anyone for any reason save one: They must not allow the information to be used for marketing" by pharmaceutical companies. $^{380}$ It was hard to maintain that the law promoted physician privacy when the law allowed wide dissemination of their data to all except one disfavored class of recipients: drug manufacturers. If the state's interest really was substantial, why was the state pursuing that interest so haphazardly?

As the Court noted in a 1999 case, Greater New Orleans Broadcasting Ass'n v. United States, ${ }^{381}$ it is "by no means self-evident" ${ }^{382}$ that a gov-

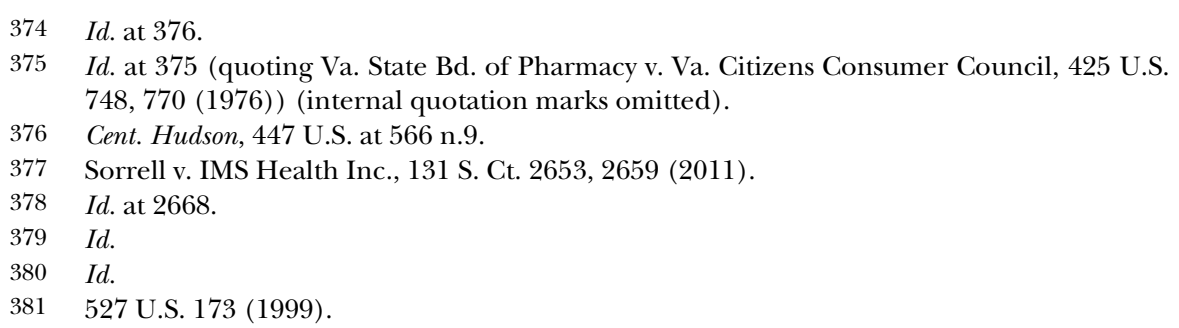


ernmental interest is substantial when the government's policies on the matter are "decidedly equivocal." 383 In Sorrell, Vermont's failure to adopt "a more coherent policy" 384 for protecting physician's confidentiality implied that the state's "asserted interest in physician confidentiality does not justify the burden" ${ }^{385}$ its law placed on protected speech.

This second point has enormous significance for return of results. Many bioethicists recommend suppressing the return of results that lack well-established clinical validity and clinical utility. ${ }^{386}$ Before giving these recommendations the force of law, the government would need to enunciate a substantial interest that is served by restricting the communication of research results that lack clinical validity and utility. That would be hard for the government to do, because the existing CLIA regulations routinely allow CLIA-certified laboratories to offer lab-developed tests ("LDTs") for use in clinical care without requiring proof that the tests have clinical validity or utility. ${ }^{387}$ Restricting the return of research results that lack clinical validity or utility would, in effect, hold experimental tests to a higher standard than CLIA requires of commercially available tests used in clinical care. The government's policy incoherence undercuts the assertion that it has a substantial interest in banning the return of research results that lack a well-established clinical validity and utility.

If the government really did have a substantial interest in suppressing communication of test results that lack established clinical validity and utility, then the government not only would ban the return of research results that fit this description but also would amend the CLIA regulation to require LDTs to pass through a data-driven review of clinical validity and utility before they can be used in clinical care. For more than fifteen years, the government has persistently ignored bioethicists' pleas to subject LDTs to such review. ${ }^{388}$ After

Id. at 186 .

Id. at 187

384 Sorrell, 131 S. Ct. at 2668 (quoting Greater New Orleans, 527 U.S. at 195) (internal quotation marks omitted).

$385 I d$. at 2668

386 See discussion supra Part II.

387 See TASk Force Of Genetic Testing, NAT'L Insts. OF HeAlth-DeP'T OF ENERGy Working GrP. ON ETHICAL, Legal \& SOCIAL IMPlications OF Human GeNOME RESEARCH, Promoting Safe and Effective Genetic Testing in the United States ch. 2 (Neil A. Holtzman \& Michael S. Watson eds., 1997), http://www.genome.gov/10002404 [hereinafter NIH-DOE Report] (discussing the problem of CLIA-regulated lab-developed tests); see also SACGT, 2000 REPORT, supra note 38; SACGHS, 2008 REPORT, supra note 80.

388 See NIH-DOE Report, supra note 387, at ch. 2 (recommending in 1997 that all genetic tests, including CLIA-regulated LDTs, should pass through a data-driven review of safety 
Sorrell and Greater New Orleans, it would be difficult for the government to maintain that it has a substantial interest in banning return of results that lack clinical validity and utility, when CLIA presently allows a vast commerce in such results for use in clinical care.

Policy incoherence also may exist in connection with CLIA's regulation of analytical claims (claims of analytical validity) as well as clinical claims (claims that a test has clinical validity and/or utility). The Secretary's Advisory Committee on Genetics, Health, and Society ("SACGHS") notes that making valid analytical measurements involves several important aspects, one of which is quality control and quality assurance ("QC" and "QA") procedures. ${ }^{389}$ CLIA requires labs to have QA programs, and a key component of these programs is proficiency testing ("PT"). ${ }^{390} \mathrm{PT}$ is viewed as "the most rigorous form of performance assessment" ${ }^{\text {391 }}$ and, when Congress authorized the CLIA program in 1988, "Congress wanted PT to 'be the central element of determining a laboratory's competence." ${ }^{\text {"92 }}$ Unfortunately, SACGHS's 2008 report found that CMS-approved PT programs were available for "only 83 specific analytes, none of which are genetic tests per se." ${ }^{\text {393 }}$ Although, in principle, all genetic tests should undergo PT, SACGHS recognized that "such a goal cannot be achieved immediately" ${ }^{394}$ because of various constraints including shortages of wellcharacterized reference materials for labs to use in PT and internal quality assurance activities. ${ }^{395}$ Such problems may be especially acute when dealing with new or novel genetic tests, such as those that are the subject of requests for return of results. In light of the various constraints SACGHS noted, it is a challenge for the CLIA program even to ensure that clinically available genetic tests have analytical validity. This again raises the question of whether calls to restrict the return of results may be holding experimental genetic tests to a higher standard than is required for tests presently used in clinical care.

and effectiveness before the tests become routinely available in clinical care and after they undergo significant modifications); SACGT, 2000 REPORT, supra note 38, at x, 15-20 (calling in the year 2000 for all genetic tests, including LDTs, to undergo data-driven reviews focusing on the analytical and clinical validity as well as on any claims the developer plans to make about a test's clinical utility). SACGHS, 2008 REPORT, supra note 80, at 67. $I d$. at 73 .

Id. at 7 .

Id. at 73 (describing H.R. 100-899's legislative history).

Id. at 7.

$I d$.

Id. at $82-83$. 
The government's interest in keeping people from being upset. A third relevant point is that the government does not have a substantial interest in keeping people from hearing factual statements that may make them anxious. Learning unpleasant facts sometimes upsets people but this is no reason for the government to suppress nonmisleading speech. In Sorrell v. IMS Health, the State of Vermont claimed that it had a substantial interest in regulating pharmaceutical companies' detailing operations because such operations may make patients "anxious." 396 The state reasoned that patients would worry that their doctors were prescribing drugs in response to drug companies' marketing efforts, instead of choosing the drug that actually is best for the patient. The Supreme Court rejected this rationale: "Speech remains protected even when it may 'stir people to action,' 'move them to tears,' or 'inflict great pain.",397 The government can and does regulate speech in situations where speakers deliberately aim to upset people, for example, if a speaker makes threats or speaks with the intention of inflicting emotional distress. ${ }^{398}$ However, commercial speech almost never has the deliberate aim of threatening or upsetting people; its aim is to convey information. Even if factual information may have the incidental effect of upsetting people, this is no reason to suppress it. Facts are friendly for purposes of the First Amendment. This is all the more true in light of recent survey data that seems to show that returning results does not actually make participants as anxious as previously was presumed. ${ }^{399}$

Conclusion: Common rationales for restricting return of results do not satisfy constitutional requirements. Table $1^{400}$ listed various justifications that bioethicists offer for suppressing the return of results. The first four items in that table appear unlikely to withstand the second step of Central Hudson analysis. Those justifications were that (1) individual findings are not reliable information that is worth communicating; (2) returning results is not effective because it may fail to motivate recipients to take steps to improve their health; (3) returning results may cause participants to feel anxious; and (4) participants may misunderstand their results. As just discussed, the government

396 Sorrell v. IMS Health Inc., 131 S. Ct. 2653, 2670 (2011).

397 Id. (quoting Snyder v. Phelps, 131 S. Ct. 1207, 1220 (2011)) (internal quotation marks omitted).

398 See, e.g., Weinstein, supra note 195, at 492 (discussing the government's ability to regulate tortious or threatening speech).

399 See Terry, supra note 112, at 713 ("In recent years, some studies suggest that there is less anxiety over receiving results than previously thought, though most studies were based on cohorts that availed themselves of [genetic] counseling."). 
does not have a substantial interest in suppressing the communication of low-value information, so long as the information is not inherently misleading. If the government could ban low-value speech, very little of what most of us say would survive. The government does not have a substantial interest in preventing people from experiencing anxiety in response to unpleasant, uncertain, or incomplete facts. The government does not have a substantial interest in keeping people from being misled by speech that is not inherently misleading. The government's interest in protecting people from being misled by such speech may support disclosure requirements, but does not support banning the speech.

D. Are Regulations Restricting the Return of Results Properly Tailored to Advance the Government's Interests?

Speech restrictions often receive their toughest scrutiny at Steps Three and Four of Central Hudson analysis. At this point, courts accept (or assume) that the government is seeking to advance a substantial interest. However, the mere fact that the state has a "laudable concern ... does not provide a constitutionally adequate reason for restricting protected speech." "If the Government can achieve its interests in a manner that does not restrict commercial speech, or that restricts less speech, the Government must do so." "Th2 The regulation must be "in proportion to that interest" and be "designed carefully to achieve the State's goal." ${ }^{403}$ Steps Three and Four of the Central Hudson test consider "whether the regulation directly advances the governmental interest asserted" ${ }^{404}$ and whether the fit between the government's ends and its means "is not necessarily perfect, but reasonable." ${ }^{\prime 05}$ These two steps are closely related and are discussed together below.

Suppressing speech that potentially may have bad consequences. As noted in Table 1, bioethicists seeking to suppress the return of results often argue that such speech may lead to bad consequences. ${ }^{406}$ For example, returning results may cause research participants to make illadvised healthcare decisions that harm them; ${ }^{407}$ it may expose them to

\footnotetext{
401 Cent. Hudson Gas \& Elec. Corp. v. Pub. Serv. Comm'n, 447 U.S. 557, 569 (1980).

402 Thompson v. W. States Med. Ctr., 535 U.S. 357, 358 (2002).

403 Cent. Hudson, 447 U.S. at 564.

$404 \quad I d$. at 566

405 Bd. of Trs. v. Fox, 492 U.S. 469, 480 (1989) (discussing Cent. Hudson, 447 U.S. at 564, $566)$.

406 See supra Table 1, items 5, 6, 8, 9, 10.

407 Id. at item 5.
} 
a risk of stigmatization or discrimination; ${ }^{408}$ it may cause them to overconsume follow-up healthcare services; ${ }^{409}$ it may divert financial resources from other worthy research projects; ${ }^{410}$ or it may cause participants to propagate inaccurate understandings of the genome as they attempt to decipher it for themselves. ${ }^{411}$ These types of arguments are perennial losers at Steps Three and Four of Central Hudson analysis. As the Supreme Court stated in Central Hudson, "We review with special care regulations that entirely suppress commercial speech in order to pursue a non-speech-related policy. In those circumstances, a ban on speech could screen from public view the underlying governmental policy." ${ }^{412}$

One of the first modern commercial speech cases, Virginia State Board of Pharmacy v. Virginia Citizens Consumer Council, ${ }^{413}$ rejected the idea of banning speech to protect people from the consequences of bad decisions they may make in response to the speech. In that case, the state feared that if the public saw ads for low-price pharmacies, people would "choose the low-cost, low-quality service and drive the 'professional' pharmacist out of business" and thus "destroy the pharmacist-customer relationship." ${ }^{414}$ If the state was concerned that low-cost pharmacies were offering low-quality service, the proper response was to revoke their licenses rather than to restrict their speech. ${ }^{415}$

The following year, in Bates $v$. State Bar of Arizona,${ }^{416}$ the state asserted that restrictions on attorney advertising were necessary to protect the public from doing business with low-quality lawyers. The Supreme Court acidly retorted, "Restraints on advertising ... are an ineffective way of deterring shoddy work." ${ }^{417}$ The state should regulate the lawyers, not their speech. By this reasoning, suppressing the return of results is an ineffective way to protect research participants from receiving ill-advised, harmful, shoddy follow-up care from the larger U.S. healthcare system. Bioethicists' eagerness to regulate what laboratories and investigators say sometimes smacks of an un-

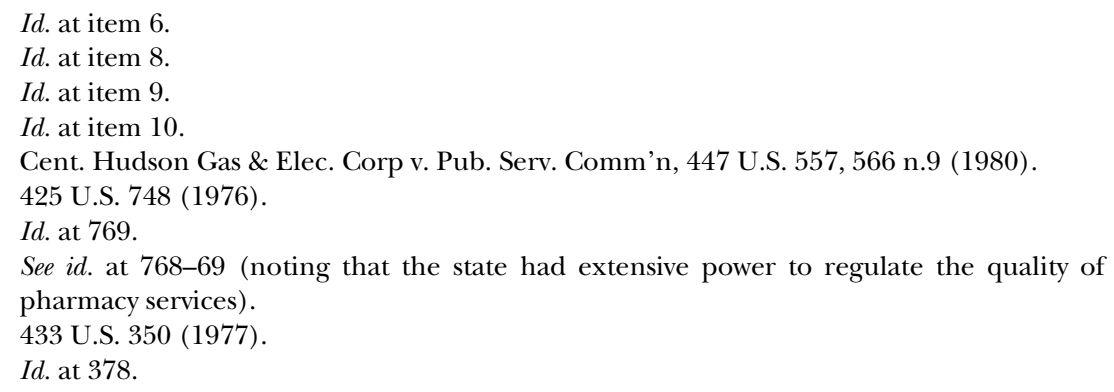


willingness to get serious about regulating what doctors do to people. If research participants seek unnecessary care based on something a genetics researcher told them, then their physicians have a duty not to provide that care. If doctors are doing so, then that is the problem bioethicists should focus on, at least as far as the Supreme Court is concerned.

Governmental attempts to use speech restrictions as a tool for advancing unrelated policy objectives also fail at Steps Three and Four of Central Hudson analysis. In Central Hudson, the state of New York had banned advertising by utility companies as a way to advance the state's objective of promoting energy conservation. ${ }^{418}$ The court acknowledged that the state has a substantial interest in energy conservation, ${ }^{419}$ but held that the advertising ban was not a proper way to advance that interest. The advertising ban did have a "direct link" to energy conservation, ${ }^{420}$ but it was more extensive than it needed to be. ${ }^{421}$ It suppressed advertising of energy-efficient consumption practices as well as wasteful ones. ${ }^{422}$ The state could have advanced energy conservation through less draconian measures such as requiring disclosures about the relative efficiency and expense of the utility services being advertised ${ }^{423}$ or pre-screening ads to eliminate only those ads that provably promoted waste. ${ }^{424}$ Justice Blackmun's concurring opinion in Central Hudson railed against the dangers inherent in allowing governmental bodies to "suppress[] . . commercial speech in order to influence public conduct through manipulation of the availability of information., ${ }^{425}$ He would have applied strict scrutiny to governmental attempts to "influence behavior by depriving citizens of information." ${ }^{426}$

Cent. Hudson Gas \& Elec. Corp v. Pub. Serv. Comm’n, 447 U.S. 557, 568 (1980). $I d$.

Id. at 569 .

Id. at 570

Id.; see also Thompson v. W. States Med. Ctr., 535 U.S. 357, 376-77 (2002) (rejecting a pharmacy advertising ban that was overbroad because, although it arguably protected patients who should not take compounded drugs, it also blocked useful speech to patients who could benefit from such drugs).

Cent. Hudson, 447 U.S. at 571.

$I d$. at $571 \mathrm{n} .13$ (arguing that such prescreening could pass constitutional muster if it included adequate procedural safeguards and citing Virginia Pharmacy Board v. Virginia Citizens Consumer Council, 425 U.S. at 771-72 n.24, as suggesting that traditional prior restraint doctrine may not apply to commercial speech).

Id. at 578 (Blackmun, J., concurring).

$I d$. at 577; see also id. at 578 ("No differences between commercial speech and other protected speech justify suppression of commercial speech in order to influence public conduct through manipulation of the availability of information."). 
In Western States, ${ }^{427}$ the FDA claimed that ban on advertising by compounding pharmacies was necessary to "preserv[e] the effectiveness and integrity of the [agency]'s new drug approval process and the protection of the public health that it provides" while simultaneously "preserv[ing] the availability of compounded drugs for those individual patients" who need them. ${ }^{428}$ The FDA reasoned that if all compounded drugs were forced to go through the FDA approval process, the drugs would become prohibitively costly for patients who need them. ${ }^{429}$ On the other hand, if the agency let pharmacy compounders advertise their products, this might become a pathway for circumventing the FDA approval process for drugs aimed at a wider market. The Court agreed that these interests were substantial. The FDA's proposed solution was to treat advertising as a trigger for requiring FDA approval. ${ }^{430}$ Compounders could continue offering their products without an FDA approval as long they did not advertise, but if compounders wanted to advertise, they would need to go through the agency's regular drug-approval process.

The Court held that this policy violated the First Amendment. If the agency's goal was to avoid mass-marketing of compounded drugs, there were more direct ways to accomplish that objective. For example, the agency could ban commercial-scale manufacturing by compounding pharmacies, or it could prohibit them from preparing a compounded drug in advance of receiving a prescription, or it could limit the overall volume of drugs that compounding pharmacies can sell in interstate commerce. ${ }^{431}$ Speech restrictions were justified only if the FDA could show that other approaches would not work. ${ }^{432}$ The agency had provided no such evidence and thus it had not justified resorting to speech restrictions. ${ }^{433}$

The dissent in Western States worried that advertising of compounded drugs would create demand among patients who did not actually need such drugs. ${ }^{434}$ The FDA, apparently aware of past cases like Virginia Board, had not even attempted such an argument, but the Court took the trouble to analyze the dissent's concern and rejected it once again. In the Court's view, the dissenters' concern that speech would create demand for unnecessary treatments "amounts to

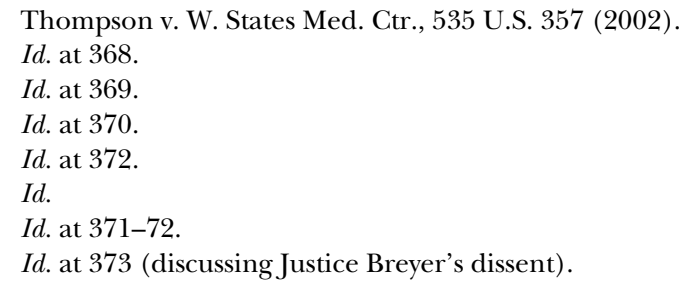


a fear that people would make bad decisions if given truthful information about compounded drugs." ${ }^{435}$ The Court noted that this fear rests on the questionable assumption that doctors would prescribe unnecessary treatments simply because misguided patients asked for them. ${ }^{436}$ Even if that assumption were true, it still would not justify a ban on advertising: $:^{437}$

[B]ans against truthful, nonmisleading commercial speech ... usually rest solely on the offensive assumption that the public will respond 'irrationally' to the truth .... The First Amendment directs us to be especially skeptical of regulations that seek to keep people in the dark for what the government perceives to be their own good. ${ }^{4}$

If the goal was to prevent inappropriate prescribing of compounded drugs, a proper solution might have been to regulate physicians' bad prescribing practices rather than to ban speech. Before it could ban speech, the FDA needed to show "why it would not also be appropriate to rely on doctors to refrain from prescribing compounded drugs to patients who do not need them in a world where advertising was permitted."

Very recently, Vermont attempted a speech-has-bad-consequences argument in Sorrell v. IMS Health and (not surprisingly) the Supreme Court rejected it. The state argued that pharmaceutical detailing raises the costs of medical services by encouraging prescription of high-cost, on-patent drugs. ${ }^{40}$ The Court acknowledged that the state's policy goals may be proper but its regulation did not advance them in a proper way. ${ }^{441}$ The state was attempting to reduce healthcare costs through the indirect means of restraining certain speech by certain speakers. ${ }^{442}$ The Court reiterated, "Those who seek to censor or burden free expression often assert that disfavored speech has adverse effects. But the fear that people would make bad decisions if given truthful information cannot justify content-based burdens on speech." 443

Addressing concerns about mix-ups. Of all the concerns that surround the return of results, perhaps the most substantial one is the

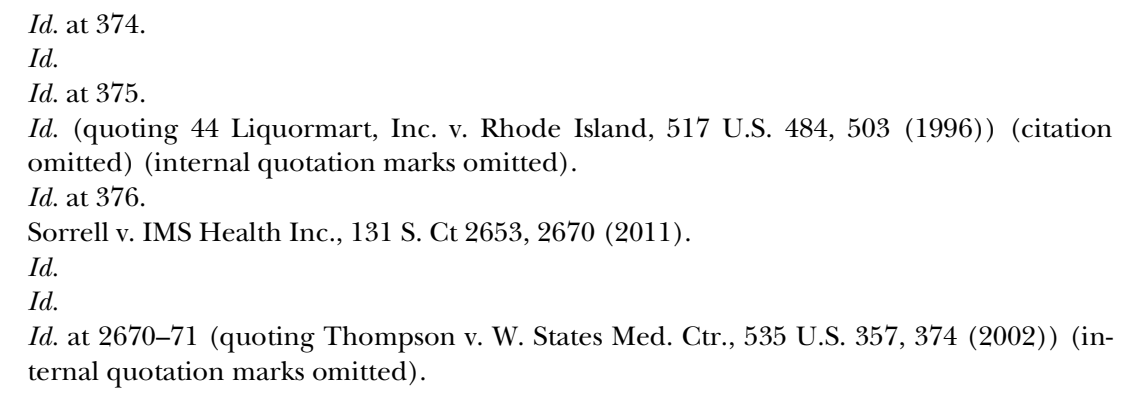


risk of potential mix-ups in which one person would receive another person's test results. When research procedures call for specimens to be used in de-identified form, there is little potential for such mix-ups to occur because de-identification renders it impossible to return results. The potential for mix-ups arises, however, if a research laboratory uses specimens in an identifiable form (coded or fully identified) yet fails to maintain appropriate controls to ensure that specimens and test results consistently and reliably can be traced back to the identities of the specimen contributors. Because CLIA requires record-keeping and sample-control procedures, requiring CLIA certification of labs that return results obviously could help reduce the chance of mix-ups. Yet, even if the government may have a substantial interest in averting mix-ups, and even if the CLIA regulation directly advances that interest, requiring CLIA certification is not the least restrictive means to advance the government's interest. CLIAcertified laboratories are subject to many requirements that go far beyond what is necessary to avoid mix-ups. CLIA requires labs to undergo periodic inspections (known as surveys) every two years to assess compliance with an wide array of requirements addressing things like the qualifications of lab personnel; CLIA also requires quality control standards, proficiency testing, and quality assurance that go considerably beyond simply keeping good records and maintaining reliable sample-control procedures. ${ }^{44}$ A less restrictive way to avoid mix-ups would be simply to require appropriate record-keeping and sample-control procedures, without requiring all the other things that CLIA requires. The notion that CLIA-certification is necessary in order to avoid mix-ups in the return of results fails at the final step of Central Hudson analysis: it is not the least restrictive means to get the job done.

Conclusion: Recommended polices to suppress the return of results are more restrictive than the Constitution allows. Even if it is true that return of results may have bad consequences, this does not justify banning the return of results. Table 3 summarizes the constitutional status of the various bioethical justifications offered in Table 1 .

444 See SACGHS, 2008 REPORT, supra note 80, at 64 (briefly summarizing CLIA regulatory requirements). 
TABLE 3

\section{CONSTITUTIONAL STATUS OF BIOETHICAL ARGUMENTS FOR RESTRICTING THE RETURN OF RESULTS}

\section{CHALlenges tO THE VALUe OF THE COMMUNiCATION}

1. Individual findings are not "information" worth communicating. These arguments appear likely to fail at Step Two of Central Hudson analysis (no substantial governmental interest in suppressing low-worth communications that are not inherently misleading). Policies to suppress the return of results that lack well-established clinical validity and utility appear particularly likely to fail at Step Two of the analysis. Concerns about analytical validity may also be subject to challenge at Step Two but, if they survive Step Two, appear likely to fail at Steps Three-Four on the basis that suppressing speech is not the least restrictive means to address uncertainty about the value of the information being returned.

2. Returning results is ineffective: even if participants are not harmed by it, they may fail to gain any benefits. Such arguments fail at Step Two (no substantial governmental interest in suppressing low-worth communications that are not inherently misleading).

\section{CONCERNS ABOUT LISTENER VULNERABILITY}

3. Returning results may expose participants to anxiety. This argument fails at Step Two (no substantial governmental interest in preventing people from feeling anxiety in response to unpleasant factual statements).

4. Participants may misunderstand their results. Some courts reject this justification at Step Two; other courts reject it at Steps Three-Four. The government cannot ban speech that is not inherently misleading. However, the government may be justified in requiring disclosure of the uncertainty and limited clinical validity and utility of experimental genetic test results. Another appropriate speech-preserving response would be for the government to ensure adequate services are available to help people understand their test results.

5. Returning results may cause participants to make bad healthcare decisions that harm them. This argument fails at Steps Three-Four. The proper response is not to suppress speech but instead to regulate physicians and healthcare organizations to deter provision of unneeded and harmful health care. 
6. Returning results exposes participants to the risk of stigmatization or discrimination. This concern fails at Steps Three-Four. Proper response is not to suppress communication of genetic test results but instead to pass laws such as the Genetic Information Nondiscrimination Act to tackle stigmatization and discrimination directly.

7. Participants' preferences to receive return of results may not reflect what they actually want. This has not been litigated. First Amendment doctrine accepts that listeners are the best parties to assess their own desire to partake of communication, and First Amendment law generally does not secondguess them. The exception would be if the listener meets criteria for decisional incompetence under the law of the state where the communication takes place-a standard that few people who have been permitted to participate in genetic research would meet.

\section{Concerns About Broader ECONOMIC ANd SOCIAL Harms to the PUblic}

8. Returning results may cause participants to over-consume follow-up healthcare services. Arguments that "speech has bad consequences" generally fail at Steps Three-Four. The proper response is not to suppress speech but to regulate physicians and healthcare organizations to deter provision of wasteful healthcare services.

9. The cost of returning results may harm the research enterprise. This is another "speech has bad consequences" argument that would fail at Steps ThreeFour. Suppressing speech is neither a direct nor least-restrictive way to address the national challenge of financing biomedical research. Moreover, the alleged high cost of returning results often reflects bioethicists' assumption that researchers must fully validate research results before they return them. Returning less-fully validated results with appropriate disclosure of the uncertainties would address the cost problem effectively without burdening free speech.

10. Participants may corrupt genetic understanding as they attempt to decipher the meaning of their test results. This argument implicates core First Amendment speech. It fails not as an intrusion on commercial speech, but as an intrusion on core First Amendment speech.

\section{E. Is the Return of Results Regulable as Professional Speech?}

It is sometimes hard to draw a clean line between commercial speech and other forms of speech that the government is free to reg- 
ulate. $^{445}$ One category of regulable speech-professional speechrequires further discussion.

Reasons for regulating professional speech. Governmental bodies have considerable latitude to regulate the "professional speech" that physicians, lawyers, and other licensed professionals communicate to their patients and clients in the course of professional practice activities. ${ }^{446}$ This does not, however, imply that all "speech by a professional" can constitutionally be regulated; the "difference between professional speech and speech by a professional is constitutionally profound." To illustrate this point, Professor Post cites a case in which a state licensing board was able to discipline a dentist for advising his patients that amalgam fillings were poisonous-advice that, in the board's view, was against the weight of scientific evidence. ${ }^{48}$ However, the board had to back off in the face of a First Amendment suit when it subsequently tried to discipline the dentist for publishing that same message in a newspaper editorial. ${ }^{449}$ The in-office advice to patients was regulable "professional speech" that could be sanctioned if it violated accepted professional standards. The same advice published in a newspaper editorial was pure "speech by a professional" ited the highest level of constitutional protection. Thus, the precise parameters and context of a communication affect how much First Amendment protection it receives.

The regulation of professional speech is justified, at least in part, by concerns about listener vulnerability. The settings in which laypeople meet with professionals may serve to make the listener vulnerable-for example, seeking treatment for an illness, seeking accounting advice about a stressful tax audit, or consulting a lawyer because one is in jail or is being sued. Moreover, it can be hard for a client or patient to evaluate claims made by licensed professionals who possess

445 See Post, supra note 200, at 21 (noting the large number of cases in which the Supreme Court has addressed the distinction between commercial speech and fully protected public discourse but a relative paucity of cases in which the Court has clarified the distinction between protected commercial speech and other forms of commercial communication that fall outside of First Amendment protection and can be regulated).

446 See Halberstam, supra note 59, at 834-38 (discussing the scope of governmental authority to regulate physicians' speech); see also Post, supra note 56, at 947-49 (discussing regulation of professional speech by physicians and dentists).

447 Post, supra note 56, at 949; see also Halberstam, supra note 59, at 843 (distinguishing speech "uttered in the course of professional practice" from speech "uttered by a professional").

448 Breiner v. State, No. CV 98061275, 1998 WL 738066, at *6 (Conn. Super. Ct. Oct. 7, 1998).

449 Post, supra note 56, at 948-49.

$450 \quad I d$. 
superior knowledge in their fields. Thus, a licensing body or other qualified group of professionals intervenes and defines the boundaries of what licensed professionals may say.

Problems with the view that return of results is practice of medicine. Regulating the return of results might be justified, from a legal point of view, if returning results were conceived as a form of professional speech. The idea here is that returning results converts the research encounter into a clinical encounter, transforming research participants into patients and thrusting investigators into the practice of medicine. The line between research and medical practice is in fact a blurry one that grows ever blurrier in the context of modern genomic medicine. ${ }^{451}$ Yet, there are conceptual problems in equating return of results with the practice of medicine and then citing this as the rationale for regulating investigators' speech.

One contradiction is that, under this theory, the return of results seemingly should be most heavily regulated in situations where results have high clinical or reproductive significance and actionability, and least regulated when the results are uncertain or lack clinical significance. When investigators return clinically significant, actionable results, the analogy between returning results and practicing medicine is at its zenith and the case for regulating the communication as "practice of medicine" is strongest. When the results have little or no clinical significance (and assuming this fact has been properly disclosed), the participant is less like a patient and the communication bears little similarity to medical practice. This implies that regulating the return of results is most justified when the results have high clinical significance and least justified when they do not.

Yet, this is directly at odds with the policies many bioethicists recommend. As discussed earlier, a number of bioethical studies recommend not returning results that lack clinical utility or actionability $^{452}$ or that have uncertain medical or reproductive significance. ${ }^{453}$ Under a professional speech analysis, speech regulation is least justified in such circumstances. Discussing genes that have no current

451 See, e.g., Wolf, supra note 37, at 444-45 (noting that return of results forces a rethinking of the traditional wall between research and clinical care); see also Barbara J. Evans, Seven Pillars of a New Evidentiary Paradigm: The Food, Drug, and Cosmetic Act Enters the Genomic Era, 85 Notre Dame L. Rev. 419, 476-85 (2010) (discussing 2007 amendments to the Food, Drug, and Cosmetic Act that envision ongoing research activities after drugs have made the transition into clinical care).

452 See Wolf et al, supra note 42, at 230-31 tbl.3 (summarizing recommendations from various bioethical studies of the return of individual research results).

453 Parker, supra note 20, at 452 ("It is generally, though not uniformly, agreed that unreliable results ought not be offered back to individuals.”). 
medical significance is not the practice of medicine; it is more in the nature of a chat about the poorly developed state of genetic science: "You have this gene variant, and nobody really knows whether it affects human health." Such remarks are better characterized as "speech by a professional" (assuming, of course, that the investigator even is a licensed medical professional) than "professional speech." ${ }^{454}$ Banning the return of results that lack clinical validity or utility cannot be justified as regulation of professional speech because such speech bears little resemblance to the practice of medicine.

Second, it would be odd indeed for the federal government to defend its various restrictions on the return of results under the theory that these are valid regulations of the practice of medicine. These restrictions arise under the CLIA regulation ${ }^{455}$ and the Common Rule, ${ }^{456}$ both regulations administered by agencies within HHS. In other HHS regulatory contexts, such as FDA regulation of medical products, the federal government has scrupulously sought to avoid intruding on the states' prerogative to regulate the practice of medicine. ${ }^{457}$ There is little real doubt that the federal government could regulate aspects of medical practice if it desired to do so, ${ }^{458}$ but as a policy matter the FDA has gone to great lengths not to regulate the practice of medicine during the seventy-five years it has been regulating under the Food, Drug, and Cosmetic Act of 1938. In light of that history, it seems almost inconceivable that HHS would assert that its restrictions

Post, supra note 56, at 949.

See discussion supra Part I.C (concerning restrictions applicable to CLIA-certified laboratories); see also discussion supra Part I.D (concerning restrictions on return of results by non-CLIA-certified labs under the CLIA research exception at 42 C.F.R. $§ 493.3$ (b) (2)).

56 See discussion supra Part I.E (concerning restrictions under the Common Rule at 45 C.F.R. pt. 46).

See, e.g., Evans, supra note 451, at 500-02, 521-23 (tracing Congress's careful avoidance, in the years between 1930 and the present, of federal intrusions into the practice of medicine in connection with federal regulation of medical products); see also David G. Adams, The Food and Drug Administration's Regulation of Health Care Professionals, in 2 FundaMENTALS OF LAW AND REgUlations: AN IN-DEPTH LOOK AT THERAPEUTIC Products 423 (David G. Adams et al. eds., 1997) ("[T] he FDA has traditionally taken the position that it does not regulate the practice of medicine or pharmacy and has generally avoided regulatory actions that would directly restrict or interfere with professional service to patients.").

458 See Adams, supra note 457, at 424-25 (noting that courts have never found constitutional limits on the FDA's power to regulate physicians); see also Richard A. Epstein, Why the FDA Must Preempt Tort Litigation: A Critique of Chevron Deference and a Response to Richard Nagare$d a, 1 \mathrm{~J}$. TORT L. art. 5, at 7 (2006) (arguing that there is little doubt under modern law that Congress has ample power to regulate the manufacture, distribution, and use of drugs and medical devices and this reasoning encompasses genetic tests insofar as genetic tests are a form of medical device). 
on the return of results are a valid federal regulation of medical speech.

There is a third contradiction in the view that return of results involves the type of "dependence or reliance" $" 459$ that justifies regulation of professional speech. At the point when participants consent to participate in research, the Common Rule conceives them to be autonomous and capable of making decisions in their own best interests. If this were not true at the point when they consented, then it may have been unethical to allow them to participate in the research or, at least, it may have been appropriate to constrain their ability to consent as is done for various categories of vulnerable individuals under the regulations at 45 C.F.R. pt. 46 , subpts. B-D. ${ }^{460}$ Thus it can reasonably be presumed that any person who has been allowed to participate in genetics research possesses the attributes of individual autonomy. Yet later, at the point when research participants request return of results, many bioethicists advocate restricting what they can be told. As Professor Post points out, the urge to suppress consensual communications often presumes that the participants are vulnerable and incapable of acting in their own best interests. ${ }^{461}$ Yet, if they are too vulnerable to make autonomous decisions about the return of results from the research, then was it ethical to involve them in the research at all?

It is of course true that vulnerability is context-dependent, and a person may be autonomous in one situation while vulnerable in another. Consenting to participate in a study of genes associated with susceptibility to cancer may be different from consenting to be told that one may actually possess such a gene. Yet, bioethicists trace a dubious line when they deem participants sufficiently autonomous to consent to research yet insufficiently autonomous to consent to return of results from that same research. If, in fact, the participants are incapable of appreciating the meaning, limitations, and uncertainty of the genetic tests used in the research, at the very least this casts doubt on whether they were adequately informed about the nature of the research to which they so recently consented. This is the inherent contradiction in policies that suppress the return of results to research participants for their own good: such policies presume that the participants have made a transition from autonomy to vul-

\footnotetext{
459 Post, supra note 200, at 23.

460 See 45 C.F.R. $\$ \S 46.201-46.409$ (imposing special constraints on the informed content process when the prospective research participants are children, pregnant women, or prisoners).

461 Post, supra note 200, at 23.
} 
nerability which, if true, begs the question whether their continued participation in the research is ethically appropriate. If the participants truly are confused about how uncertain experimental genetic tests actually are, then their consent to the research may have been tainted by misperceptions of its scientific value.

This is not to deny that research participants may be vulnerable in the context of conversations that return research results. However, to justify restricting investigators' speech, bioethicists would need to explain more precisely how and why the participants became vulnerable and what this vulnerability implies for other aspects of research where they were presumed to be autonomous.

Conclusion: Return of results is not regulable as professional speech. Arguing that restrictions on the return of results are justified as a regulation of professional speech raises more questions than it resolves. An enduring concern in bioethics is that research participants may labor under a therapeutic misconception that causes them to confuse research with medical practice. Yet, when bioethicists attempt to justify regulating the return of results because of its alleged similarity to professional speech, it is the bioethicists rather than the research participants who fall prey to the therapeutic misconception. Return of results is not the practice of medicine despite some overlap of the topics discussed. HHS agencies that restrict the return of results seem poorly positioned to assert otherwise. If HHS truly believed that returning results amounts to the practice of medicine, its traditional posture on federalism seemingly would require HHS agencies to step aside and let state medical practice boards regulate this speech.

\section{SPecial Problems With CLIA RESTRICTIONS ON THE RETURN OF RESULTS}

The CLIA regulation exemplifies the First Amendment problems that arise in connection with suppression of genomic speech. As noted earlier, HHS already has initiated a rulemaking that will facilitate direct reporting of test results from CLIA-certified clinical laboratories that are subject to the HIPAA Privacy Rule. ${ }^{462}$ HHS based this action on concern about patients' rights ${ }^{463}$ while also noting that "the advent of certain health reform concepts (for example, individual-

\footnotetext{
462 See discussion supra Part I.C (citing CLIA Program and HIPAA Privacy Rule, supra note 52 , at 56,717$)$.

463 See CLIA Program and HIPAA Privacy Rule, supra note 52, at 56,714 (citing a need to increase direct patient access rights).
} 
ized medicine and an individual's active involvement in his or her own health care) would be best served by revisiting CLIA limitations on the disclosure of laboratory test results. ${ }^{264}$ Even if this initiative proceeds to a final rule, however, it will only improve access to genetic test results in situations where the test subject is dealing with an entity covered by the HIPAA Privacy Rule. Moreover, this rulemaking initiative does nothing to address the return of results from nonCLIA-certified research laboratories. The CLIA research exception at 42 C.F.R. $\S 493.3$ (b) (2) continues to be perceived as a major barrier to the return of research results. ${ }^{465}$

The CLIA research exception places regulatory burdens on research laboratories (by requiring them to seek CLIA certification) if they "report patient specific results for the diagnosis, prevention, or treatment of any disease or impairment of, or the assessment of the health of individual patients." ${ }^{466}$ Administrative law judges who work with CLIA sometimes summarize this condition by saying that CLIA certification is required if a lab "perform[s] clinical diagnostic tests on human specimens." ${ }^{467}$ Phrased this way, it seems clear that returning results should not give rise to an obligation for a research lab to seek CLIA certification because, quite obviously, an experimental genetic test is not the same thing as a clinical diagnostic test.

Yet, in practice, this is not very clear. The research exception is so vague that people of ordinary intelligence cannot assess which types of speech it prohibits. ${ }^{468}$ In particular, the research community is unsure whether returning individual research results to participants may trigger CLIA's certification requirements. ${ }^{49}$ Can an experimental genetic test that has no known clinical validity and utility be considered a test for "diagnosis, prevention, treatment ... or assessment of health?” One would think not. Yet, CLIA regularly allows LDTs that have poorly validated clinical validity and utility to be used in clinical care, ${ }^{470}$ so the lack of clinical significance does not necessarily exclude an experimental test from being "clinical." At the other extreme, suppose an experimental test does have clinical validity and utility. Does this fact transform it into a "clinical diagnostic test[]" ${ }^{471}$ that, if

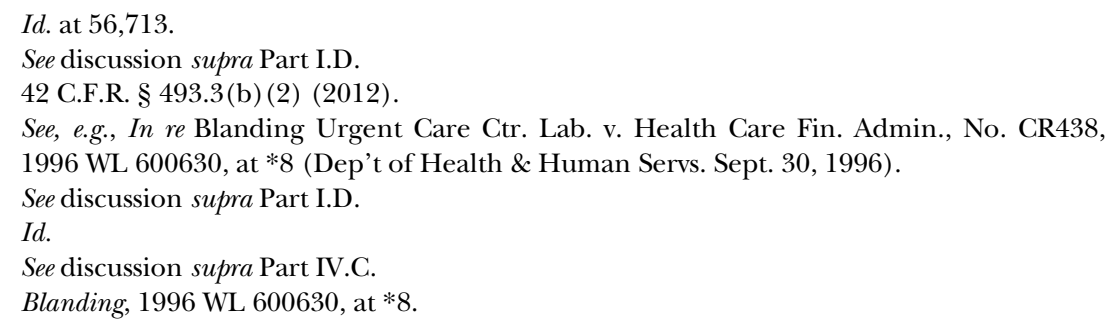


reported to the research participant, triggers the need for CLIA certification? The most sensible answer to this question appears to be no. The CLIA regulation has severed the concept of a clinical diagnostic test from the concept of a test that has well-established clinical validity and utility. The regulation does not condition the "clinical" status of a test upon a scientific evidentiary standard that requires proof of clinical validity and utility. If LDTs that lack clinical validity can be sold as clinical diagnostic tests, ${ }^{472}$ the flipside seemingly should be that experimental tests do not become clinical tests merely by token of having clinical validity and utility. But, can an investigator be sure?

Whether returning a test result triggers CLIA's certification requirements simply cannot be inferred from the scientific attributes of the test. The regulation provides no guidance on other factors that may bear on this determination-for example, the subjective intent of the speaker, the listener's actual use of the information, and so forth. ${ }^{473}$ Given the vagueness of this regulation, scientific investigators working in non-CLIA-certified research laboratories are understandably hesitant to return results, especially in light of the following:

Any person who intentionally violates any requirement [of the CLIA regulation] shall be imprisoned for not more than one year or fined under title 18, or both, except that if the conviction is for a second or subsequent violation of such requirement such person shall be imprisoned for not more than 3 years or fined in accordance with title 18 , or both. ${ }^{474}$

Perhaps it displays the advancement of our post-genomic civilization that CLIA only threatens jail time for investigators who inappropriately let laypeople read the Book of Life, whereas Tyndale was put to death. The possibility of criminal penalties for violating CLIA's research exception amplifies the constitutional problem with its vagueness. The standard of clarity required in criminal statutes is far more demanding than in statutes that only carry civil penalties. ${ }^{475}$ "It would be unthinkable to incarcerate someone for violating a law which she could not possibly understand."

See discussion supra Part IV.C.

See discussion supra Part II.D.

Public Health Service Act $\S 353(1)$, 42 U.S.C.A. $\$ 263 a(1)$ (2006); see also 42 C.F.R. $\S 493.1806$ (e) (1994) ("Under section 353(1) of the PHS Act, an individual who is convicted of intentionally violating any CLIA requirement may be imprisoned or fined.").

475 See Vill. of Hoffman Estates v. Flipside, Hoffman Estates, Inc., 455 U.S. 489, 498-99 (1982) (discussing the Court's greater tolerance of vagueness in civil, as opposed to criminal, statutes).

476 Ass'n of Nat'l Advertisers v. Lungren (Lungren I), 809 F. Supp. 747, 761 (N.D. Cal., 1992) (citing Barenblatt v. United States, 360 U.S. 109, 137 (1959) (Black, J., dissenting)). 
Suppose an investigator spots a gene mutation that suggests that a research participant needs to report to her doctor immediately for a colonoscopy to address the risk of colon cancer. Unfortunately, the genetic test was performed in a research laboratory that lacks CLIA certification, and the investigator is worried it may violate CLIA's research exception to disclose the test result to the research participant. CLIA confronts this investigator with the possibility-at least in theory-of going to jail for sharing potentially life-saving information with the research participant. It is true that criminal law recognizes a privilege for people to violate criminal statutes when necessary to save a third party from death or serious bodily injury. The investigator seemingly would be entitled to claim this privilege as a defense. But, is it constitutional for CLIA to place investigators in the position of having to make such choices?

HHS cannot skirt this constitutional problem by arguing that the agency does not, in practice, apply CLIA's criminal penalties to investigators who return research results. The Supreme Court has made it very clear that " $[\mathrm{w}]$ ell-intentioned prosecutors and judicial safeguards do not neutralize the vice of a vague law." ${ }^{477}$ In a First Amendment challenge to a California statute that envisioned criminal penalties for manufacturers who make inappropriate environmental claims about their products, the state argued that its "traditional office policy" was to handle violations civilly rather than criminally. ${ }^{478}$ The court retorted, "This will not do" ${ }^{\text {"479 }}$ and proceeded to rule that the statute's definition of the term "recyclable" was unconstitutionally vague. ${ }^{480}$ In the same way, even if HHS has no plans to impose criminal penalties for violation of CLIA's vague research exception, this will not do; there still is a constitutional problem.

Vague laws pose constitutional problems even when they carry no threat of criminal prosecution. There is a general principle that laws must be definite to be valid. ${ }^{481}$ Vague laws leave individuals unsure which activities are prohibited and leave regulators without explicit standards to guide consistent, fair enforcement. ${ }^{482}$ "[W] hen a law regulates conduct protected by the First Amendment, the vagueness

\footnotetext{
477 Baggett v. Bullitt, 377 U.S. 360, 373 (1964).

478 Lungren I, 809 F. Supp. at 761 n.14.

479 Id.; see also Ass'n of Nat'l Advertisers v. Lungren (Lungren II), 44 F.3d 726, 728 n.1 (9th Cir. 1994) (noting, in the appeal of Lungren I, that the state chose not to appeal the District Court's ruling that the definition of "recyclable" was unconstitutionally vague).

$480 \quad$ Lungren I, 809 F. Supp. at 762.

481 GeORge Blum ET AL., AM. JuR. 2D Constitutional Law $\$ 972$ (2013) (discussing definiteness or vagueness of laws, regulations, and orders). 
doctrine demands an even 'greater degree of specificity than in other contexts" " 483 and laws can be set aside if they are too vague. Courts traditionally apply this concept in a "watered down" manner when the speech in question is only commercial speech. ${ }^{484}$ As the Supreme Court mused in Central Hudson, commercial speech is a "hardy breed of expression" driven by speakers' economic self-interests and, as such, it is "not particularly susceptible to being crushed." ${ }^{485}$ Based on this reasoning, courts often are willing to tolerate a bit more vagueness in laws that regulate commercial speech than they would tolerate in laws that regulate pure speech. ${ }^{486}$

Several factors suggest that courts would not be willing to tolerate the level of vagueness apparent in CLIA's research exception. Although the speech in question-return of results-may qualify as commercial speech, it is not driven by the speaker's economic selfinterests in the way that commercial speech usually is. Investigators return results gratis and, indeed, they do so at a perceived risk of having their federal research grants suspended if an IRB decides their speech was unethical (whatever that means). Economic self-interest does not favor this speech; rather, it reinforces the pressure not to speak. Return of results is not the "hardy breed of expression" for which courts have been willing to apply a relaxed vagueness doctrine. Moreover, the return of results includes some expressive (pure speech) elements that may warrant stronger protection than mere commercial speech. This Article deliberately blinded itself to those expressive elements as a matter of rigorous study design, but they undeniably are present and may call for application of a less-relaxed vagueness doctrine. Finally, the potential for criminal penalties under the CLIA regulation argues against a relaxed attitude about the research exception's vagueness.

The Supreme Court mandates that a "statute, of course, is to be construed, if such a construction is fairly possible, to avoid raising

\footnotetext{
483 Lungren I, 809 F. Supp. at 759 (quoting Smith v. Goguen, 415 U.S. 566, 573 (1974)).

4841 RodNEy A. SMOlla, SMOlla \& NimMER ON FreEdom OF SPEECH § 6:12 (2013).

485 Cent. Hudson Gas \& Elec. Corp. v. Pub. Serv. Comm'n, 447 U.S. 557, 564 n.6 (1980) (quoting Bates v. State Bar of Ariz., 433 U.S. 350, 381 (1977)) (internal quotation marks omitted) (discussing why overbroad regulations are less threatening to commercial speech than to pure speech). commercial speech we frame our decisions narrowly, allowing modes of regulation ... that might otherwise be impermissible within the realm of personal expression." (citation omitted)); Vill. of Hoffman Estates v. Flipside, Hoffman Estates, Inc., 455 U.S. 489, 498 (1982) (articulating a relaxed vagueness test in a commercial speech context).
} 
doubts of its constitutionality." ${ }^{487}$ There are, to say the very least, doubts about whether it is constitutional for HHS to construe CLIA's research exception in a way that bans the return of individual results from genetic research. ${ }^{488}$ CLIA's research exception must therefore be construed in a way that removes these doubts. It appears likely that courts would do so if the question were put before them. It is to be hoped that HHS will take the initiative and fix this problem without putting investigators and research participants to the expense of petitioning federal courts to order HHS to do so. If HHS fails to act, then court challenges are in order. HHS should clarify that the CLIA research exception does not ban the return of genetic test results to research participants who have expressed the desire to learn their results. This is not merely an ethical imperative; it is a constitutional imperative.

\section{CONCLUSION}

Many layers of state and federal laws limit investigators' freedom to communicate with willing participants who request the return of results. To assess the constitutionality of these laws, each of them ultimately will require a separate, evidence-based analysis of the government's asserted interests and whether the regulation advances them directly and without unnecessary burdens on speech. This Article has surveyed relevant themes in First Amendment law drawn from cases that addressed questions similar to those that arise in the context of return of results. These cases suggest that laws and regulations that restrict the return of results are vulnerable to First Amendment challenges. This Article has not, however, mounted an evidencebased challenge to specific laws. The duty to produce evidence lies with those who champion speech restrictions, not on those who question them. It is long past time for the bioethics community and policymakers to produce credible evidence that the harms they conjecture are real; that the government's interests in addressing these harms are of a sort that courts, in actual cases, have treated as substantial; that suppressing the speech of research investigators directly advances those interests; and that no less extensive burden on speech will work. If-as looks probable-no such evidence exists, then the bioethics community, with all due respect, needs to retire from the 
business of suppressing investigators' constitutionally protected speech. 